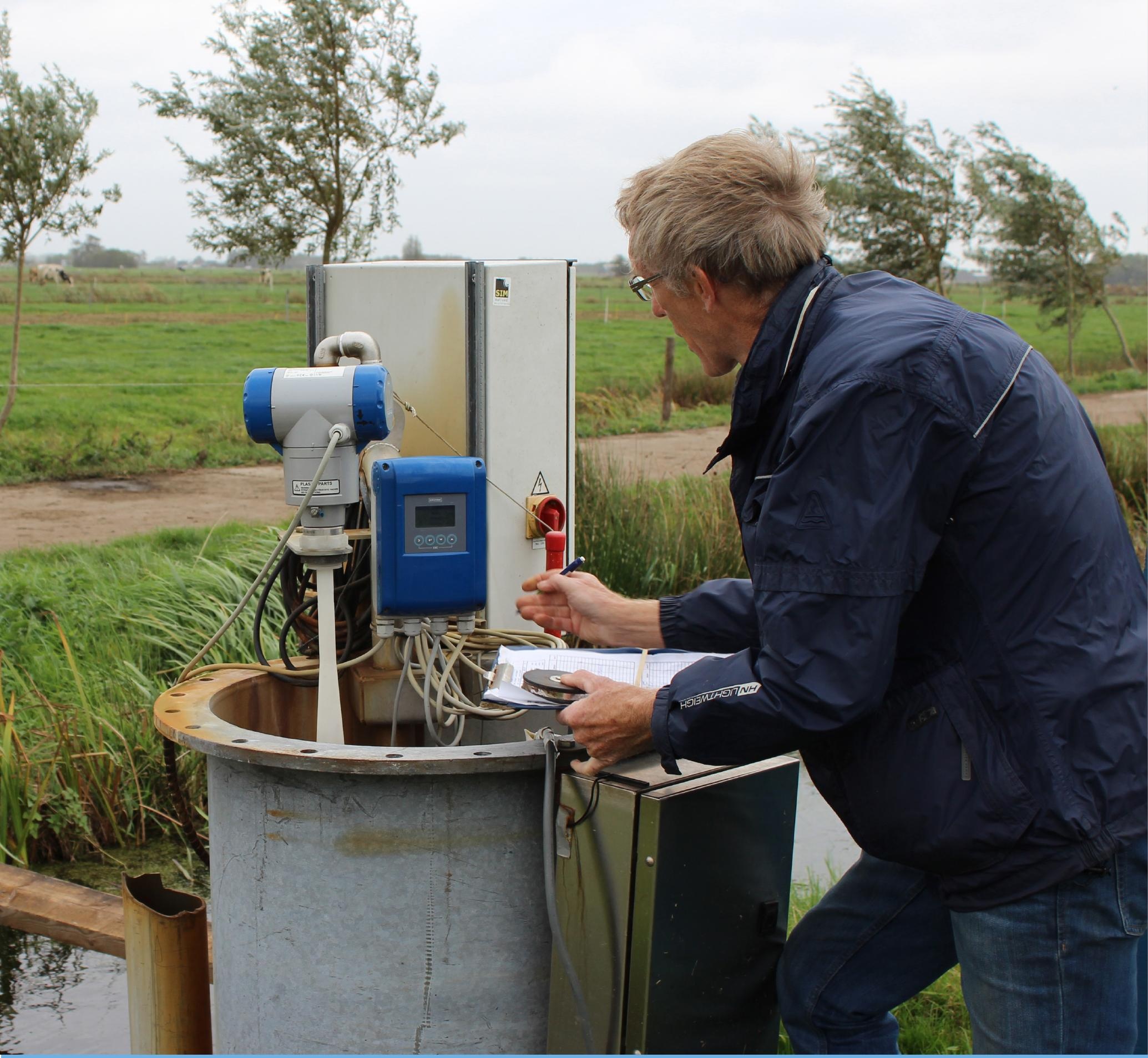

Precisiewatermanagement op veenweidegrond met pompgestuurde onderwaterdrains

I.E. Hoving, J.J.H. van den Akker, H.T.L. Massop, G.J. Holshof en K. van Houwelingen

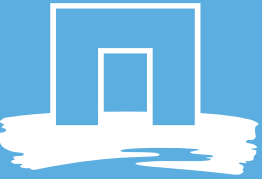





\section{Precisiewatermanagement op veenweidegrond met pompgestuurde onderwaterdrains}

Auteurs

I.E. Hoving ${ }^{1}$, J.J.H. van den Akker $^{2}$, H.T.L. Massop ${ }^{2}$, G.J. Holshof ${ }^{1}$ en K. van Houwelingen ${ }^{3}$

1 Wageningen Livestock Research

2 Wageningen Environmental Research

3 Kennis Transfer Centrum (KTC) Zegveld

Dit onderzoek is uitgevoerd door Wageningen Livestock Research en is mogelijk gemaakt door een bijdrage van ZuiveINL, provincie Utrecht, provincie Zuid-Holland, Waternet, Wetterskip Fryslân en Hoogheemraadschap de Stichtse Rijnlanden

Wageningen Livestock Research

Wageningen, september 2018
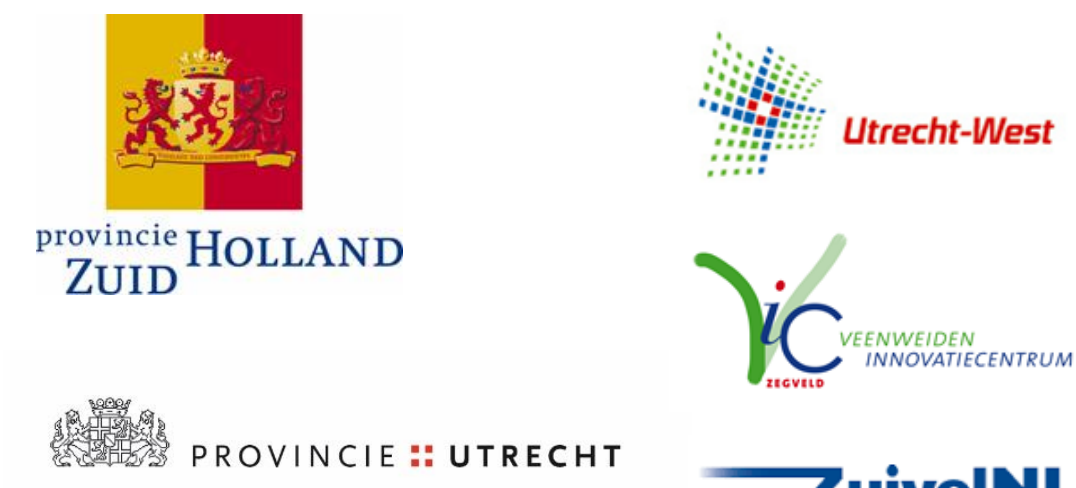

Rapport 1123

EENWEIDEN
INNOVATIECENTRUM

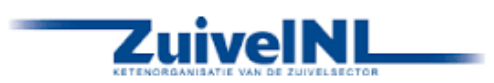


Hoving I.E., A., J.J.H. van den Akker, H.T.L. Massop, G.J. Holshof, K. van Houwelingen, 2018. Precisiewatermanagement met pompgestuurde onderwaterdrains op veenweidegrond. Wageningen Livestock Research, Rapport 1123

\section{Samenvatting NL}

Kenmerkend voor veengrond is de grote weerstand voor watertransport in de bodem van en naar de sloot. Onderwaterdrains zijn een effectief hulpmiddel om het watertransport in de bodem te versnellen en dit zorgt voor een significant vlakker grondwaterstandsverloop. De werking van onderwaterdrains is echter sterk afhankelijk van het slootpeil, welke niet of slechts beperkt veranderd kan worden. Door drainagebuizen op een afgesloten waterreservoir aan te sluiten kan met een pomp de grondwaterstand onafhankelijk van het slootpeil geregeld worden. De drainerende en infiltrerende werking verbetert hierdoor aanzienlijk.

\section{Summary UK}

Characteristic of peat soil is the great resistance for water transport in the soil to and from the ditch. Submerged drains are an effective tool to accelerate water transport in the soil and this results in a significantly flatter groundwater table. The operation of submerged drains is, however, highly dependent on the ditch water level, which cannot easily be changed. By connecting drain pipes to a closed water reservoir, the groundwater table can be regulated with a pump independently of the ditch water level. Therefore the draining and infiltrating effect improves considerably.

Dit rapport is gratis te downloaden op https://doi.org/10.18174/461252 of op www.wur.nl/livestock-research (onder Wageningen Livestock Research publicaties).

\section{(C) 2018 Wageningen Livestock Research}

Postbus 338, 6700 AH Wageningen, T 03174839 53, E info.livestockresearch@wur.nl, www.wur.nl/livestock-research. Wageningen Livestock Research is onderdeel van Wageningen University \& Research.

Wageningen Livestock Research aanvaardt geen aansprakelijkheid voor eventuele schade voortvloeiend uit het gebruik van de resultaten van dit onderzoek of de toepassing van de adviezen.

Alle rechten voorbehouden. Niets uit deze uitgave mag worden vermenigvuldigd en/of openbaar gemaakt worden door middel van druk, fotokopie, microfilm of op welke wijze dan ook zonder voorafgaande toestemming van de uitgever of auteur.

Wageningen Livestock Research is NEN-EN-ISO 9001:2015 gecertificeerd. Op al onze onderzoeksopdrachten zijn de Algemene Voorwaarden van de Animal Sciences Group van toepassing. Deze zijn gedeponeerd bij de Arrondissementsrechtbank Zwolle. 


\section{Inhoud}

$\begin{array}{ll}\text { Woord vooraf } & 5\end{array}$

$\begin{array}{ll}\text { Samenvatting } & 7\end{array}$

1

$\begin{array}{ll}\text { Inleiding } & 9\end{array}$

2

$\begin{array}{ll}\text { Toepassing onderwaterdrains } & 10\end{array}$

$2.1 \quad$ Effect op grondwaterstand $\quad 10$

2.2 Grasopbrengst en ruweiwit $\quad 12$

2.3 Kosten en baten boer en maatschappij 14

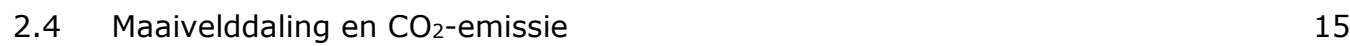

3

$\begin{array}{lr}\text { Materiaal en methode } & 19\end{array}$

$\begin{array}{lll}3.1 & \text { Bodemkarakteristiek proeflocatie } & 19\end{array}$

3.2 Proefopzet 20

$\begin{array}{lll}3.3 & \text { Peilbeheer } & 22\end{array}$

3.4 Teelt en bemesting $\quad 23$

3.5 Waarnemingen $\quad 23$

3.6 Neerslag $\quad 24$

$\begin{array}{lll}3.7 & \text { Analyse } & 25\end{array}$

$\begin{array}{llr}4 & \text { Resultaten } & 26\end{array}$

4.1 Grondwaterstanden $\quad 26$

4.2 Watergebruik $\quad 29$

$\begin{array}{lll}4.3 & \text { Grasopbrengsten } & 31\end{array}$

$\begin{array}{lll}4.4 & \text { Botanische samenstelling } & 34\end{array}$

4.5 Ontwikkeling voorzieningen pompaansturing 35

$\begin{array}{lll}5 & \text { Discussie } & 38\end{array}$

$6 \quad$ Conclusies en aanbevelingen 442

$\begin{array}{llr}7 & \text { Vervolg } & 43\end{array}$

8 Bronnen $\quad 45$

$\begin{array}{lll}\text { Bijlage 1 Bodeminventarisatie } & 47\end{array}$

$\begin{array}{lll}\text { Bijlage } 2 & \text { Plattegrond proeflocatie } & 51\end{array}$

Bijlage 3 Logboek pompaansturing $\quad 52$

$\begin{array}{lll}\text { Bijlage } 4 & \text { Variatie in grondwaterstanden } & 54\end{array}$

Bijlage 5 Vergelijk metingen grondwaterstand 56

$\begin{array}{lll}\text { Bijlage } 6 & \text { Grasopbrengst } & 58\end{array}$

$\begin{array}{lll}\text { Bijlage } 7 & \text { Stikstofopbrengst } & 60\end{array}$

$\begin{array}{lll}\text { Bijlage } 8 & \text { Botanische samenstelling } & 62\end{array}$ 


\section{Woord vooraf}

Onderwaterdrains zijn in potentie een effectief middel om veenafbraak te verminderen. Veenafbraak is niet alleen nadelig voor bodemdaling, maar het levert ook een aanzienlijke bijdrage aan de $\mathrm{CO}_{2}-$ emissie. Met name voor het beperken van de opwarming van de aarde is dit laatste aspect van toenemend belang. Bovendien is het aanpassen van slootpeilen aan maaivelddaling eindig. Het substantieel remmen van de autonome veenafbraak is dus gewenst om veenweidegrond nog voor een lange tijd te kunnen blijven gebruiken voor de veehouderij. Een toename van vernatting leidt tot opbrengstreductie (natschade) en verminderde gebruiksmogelijkheden van grasland. Dit is nadelig voor het rendement van melkveebedrijven.

De toepassing van onderwaterdrains wordt als een belangrijke maatregel gezien om zowel vernatting als bodemdaling en $\mathrm{CO}_{2}$-emissie te reduceren. Het aanleggen van onderwaterdrains vraagt echter een aanzienlijke investering, waarbij een goede werking zo goed mogelijk geborgd moet worden. Het slootpeilregime dat hierbij gehanteerd wordt is hierin een belangrijke factor.

Onderzocht is of met pompgestuurde onderwaterdrains de werking van onderwaterdrains versterkt kan worden en of de werking minder afhankelijk wordt van het slootpeil. Het onderzoek is mogelijk gemaakt door een bijdrage van ZuivelNL, provincie Utrecht, provincie Zuid-Holland, Waternet, Wetterskip Fryslân en Hoogheemraadschap de Stichtse Rijnlanden. Het onderzoek is uitgevoerd in samenwerking met melkveeproefbedrijf KTC Zegveld en Wageningen Environmental Research. Met dit rapport beogen we een bijdrage te leveren aan het verduurzamen van de melkveehouderij op veengrond.

Dr. drs. I.D. de Wolf

Afdelingshoofd Veehouderij \& Omgeving, Wageningen Livestock Research 


\section{Samenvatting}

Onderwaterdrains versnellen het watertransport in de bodem. Om de werking te vergroten is de volgende ontwikkelstap in de toepassing van onderwaterdrains het actief aan- en afvoeren van water met een pomp. Hierbij zijn de drains aangesloten op een waterreservoir en staan deze niet meer rechtstreeks in verbinding met een sloot. Met het instellen van een peil in het waterreservoir kan de aan- en afvoer van water worden vergroot. Deze vorm van precisiewatermanagement beoogt de bodemdaling en $\mathrm{CO}_{2}$-emissie te verminderen, de draagkracht van de graszode te verbeteren en de grasbenutting te verhogen.

Eerdere veldexperimenten hebben aangetoond dat bij toepassing van onderwaterdrains het grondwaterstandsverloop significant vlakker is. Het is dus een effectief hulpmiddel om grondwaterstanden te beïnvloeden. Dit vergroot in het algemeen de gebruiksmogelijkheden van het grasland, echter tijdens forse neerslagpieken treedt ook bij onderwaterdrains vernatting op. Onderwaterdrains zorgen voor kortsluiting tussen de bodem en de sloot waardoor het watertransport versnelt. De werking van onderwaterdrains is echter sterk afhankelijk van het waterpeil in de sloot. De mate waarin water wordt aan- of afgevoerd hangt sterk af van het drukverschil tussen het grondwaterpeil en het slootpeil. Het drukverschil is met het slootpeil slechts in beperkte mate te beïnvloeden. Door de buisdrains op een afgesloten waterreservoir aan te sluiten kan met een pomp een veel groter peilbereik gerealiseerd worden en is het mogelijk om daadwerkelijk op de grondwaterstand te sturen.

Om deze innovatie te testen is op het melkveeproefbedrijf KTC Zegveld in 2016 en 2017 een veldexperiment uitgevoerd. Het onderzoek had als doel om te zien of onderwaterdrains met pompaansturing effect heeft op het grondwaterstandsverloop en om de aan- en afvoer van water (zover mogelijk) te kwantificeren. Daarbij is een systeem ontwikkeld waarmee de bemaling aangestuurd kan worden op basis van de actuele grondwaterstand en de neerslagverwachting. Het onderzoek is uitgevoerd bij een hoog slootpeil van $20 \mathrm{~cm}$ en een lager slootpeil van $55 \mathrm{~cm}$ beneden maaiveld. Binnen het hoge en lage slootwaterpeilregime is gekeken hoe de pompgestuurde onderwaterdrains zich verhouden tot een ongedraineerde situatie en gangbare onderwaterdrains op de sloot. Op de onderzoeksobjecten zijn de grasopbrengsten bepaald en is het stikstofgehalte van het gras geanalyseerd.

In beide jaren was zowel het infiltrerende als het drainerende effect van pompgestuurde onderwaterdrains aanmerkelijk groter dan bij onderwaterdrains op de sloot. Het resultaat van de pompaansturing was onafhankelijk van het slootpeil. De wateraanvoer was echter bij het lage slootpeil 2,5 keer groter dan bij een hoog slootpeil. De waterafvoer was nagenoeg gelijk. De werking van de pompgestuurde onderwaterdrains geeft veel perspectief voor het verder kunnen reduceren van maaiveldaling en $\mathrm{CO}_{2}$-emissie. Een berekende schatting bedraagt 59 à $63 \%$ ten opzichte van de situatie zonder onderwaterdrains, echter de schatting is sterk afhankelijk van de gerealiseerde grondwaterpeilen. Alleen door zeer scherp te sturen op de grondwaterstand kan de maaivelddaling en $\mathrm{CO}_{2}$-emissie fors terug gebracht worden.

De verschillende drainagebehandelingen en slootpeilen hadden geen effect op de drogestofopbrengst. Wel waren er significante verschillen tussen de kalenderjaren en had stikstofbemesting een significant verhogend effect op de grasopbrengst. Alleen in 2017 (droger dan 2016) waren de stikstofopbrengsten voor pompgestuurde onderwaterdrains significant lager dan voor de situatie zonder onderwaterdrains. Het is waarschijnlijk dat dit kwam door een geringere veenafbraak als gevolg van het hogere grondwaterpeil bij pompgestuurde onderwaterdrains. 


\section{$1 \quad$ Inleiding}

Eerdere veldexperimenten hebben aangetoond dat bij toepassing van onderwaterdrains het grondwaterstandsverloop significant vlakker is (Hoving et al., 2008, 2013 en 2015; Van den Akker et al., 2013; Hendriks et al., 2013). Daarmee zijn onderwaterdrains een effectief hulpmiddel om grondwaterstanden te beïnvloeden. Dit is gunstig voor het verminderen van bodemdaling en $\mathrm{CO}_{2}-$ emissie en het vergroot de gebruiksmogelijkheden van grasland. Uit monitoring van de maaivelddaling blijkt dat onderwaterdrains de maaivelddaling met ongeveer 50 procent verminderden doordat de grondwaterstand in droge perioden in het zomerhalfjaar minder ver daalde (Van den Akker et al., 2007, 2010, 2012 en 2017). Door de hogere grondwaterstand treedt zuurstof minder ver in de bodem waardoor de veenafbraak reduceert (Schothorst, 1982). Hierdoor wordt ook de $\mathrm{CO}_{2}$-emissie verminderd (Van den Akker et al., 2007, 2008, 2012; Hendriks et al., 2008).

Onderwaterdrains zorgen weliswaar voor extra water aan- en afvoer in de bodem, echter tijdens forse neerslagpieken blijven grondwaterstanden tot in het maaiveld stijgen. Voor melkveehouders is het essentieel dat vernatting substantieel vermindert, omdat anders een investering in onderwaterdrains geen of onvoldoende profijt oplevert. Door de steeds verdergaande maaivelddaling is het blijven aanpassen van peilbesluiten geen vanzelfsprekendheid meer en wordt ook maaivelddaling een belangrijk argument voor melkveehouders om in onderwaterdrains te investeren. Voor zowel het tegengaan van vernatting als van maaivelddaling is een zo groot mogelijke effectiviteit gewenst om een investering in onderwaterdrains voldoende te laten renderen.

Om de werking van onderwaterdrains te vergroten is het actief aan- en afvoeren van water met een pomp een volgende ontwikkelstap in de toepassing van onderwaterdrains. Hierbij zijn de drains aangesloten op een waterreservoir en staan deze niet meer rechtstreeks in verbinding met een sloot. Doordat het waterreservoir boven het maaiveld uitsteekt en tot onder het drainniveau reikt, kan met het instellen van een peil in het waterreservoir een groter potentiaalverschil met de grondwaterstand worden bereikt dan met het slootpeil. Hierdoor kan in potentie de aan- en afvoer van water worden vergroot.

Daarmee wordt het grondwaterpeil leidend in het watermanagement. Dit vraagt om inzicht in de actuele grondwaterstand, de weersverwachting en de vochttoestand van de bovengrond. Hiertoe moet een besturingssysteem worden ontworpen die deze factoren inzichtelijk maakt en de pomp op afstand automatisch kan aansturen. De verwachting is dat met het toepassen van onderwaterdrains en pompaansturing het grondwaterstandsverloop onafhankelijk van het slootpeil te reguleren is.

De geschetste innovatie is in een veldexperiment op melkveeproefbedrijf KTC Zegveld getest. Het experiment had als doel om te zien of de pompgestuurde onderwaterdrains effect hebben op het grondwaterstandsverloop en om de aan- en afvoer van water te kwantificeren. Daarbij is een start gemaakt met de ontwikkeling van een systeem dat de bemaling automatisch aanstuurt op basis van de actuele grondwaterstand, de vochttoestand van de bodem en de weersvoorspelling. Voor de aansturing van de elektrische pomp is een prototype webapplicatie gemaakt. Naast het effect van precisiewatermanagement op het verloop van de grondwaterstand is onderzocht wat het effect is op de grasproductie en het eiwitgehalte van het gras.

In dit rapport staan in eerste plaats de resultaten van het veldexperiment beschreven, maar is ook het perspectief van pompgestuurde onderwaterdrains in een bredere context geplaatst. De uitkomsten van het onderzoek, de discussie van de resultaten en de aanbevelingen zijn van waarde voor de daadwerkelijke toepassing van onderwaterdrains in de praktijk, al of niet in combinatie met aansturing door middel van een pomp. 


\section{Toepassing onderwaterdrains}

\section{$2.1 \quad$ Effect op grondwaterstand}

In het onderzoek naar de hydrologische en landbouwkundige effecten van onderwaterdrains op veengrond zijn in de afgelopen 14 jaar een aantal ontwikkelstappen doorlopen. De eerste stap was om te zien of onderwaterdrains daadwerkelijk de aanvoer van water (infiltratie) en de afvoer van water (drainage) in de bodem konden bevorderen. Dit kan leiden tot respectievelijk minder maaivelddaling en een betere draagkracht van de graszode. De buisdrains liggen daarbij op 70 à $75 \mathrm{~cm}$ beneden maaiveld, ten minste $15 \mathrm{~cm}$ onder het slootpeil, zodat ze zowel water kunnen afvoeren als water kunnen aanvoeren. Een afbeelding van een onderwaterdrain staat in Figuur 1.

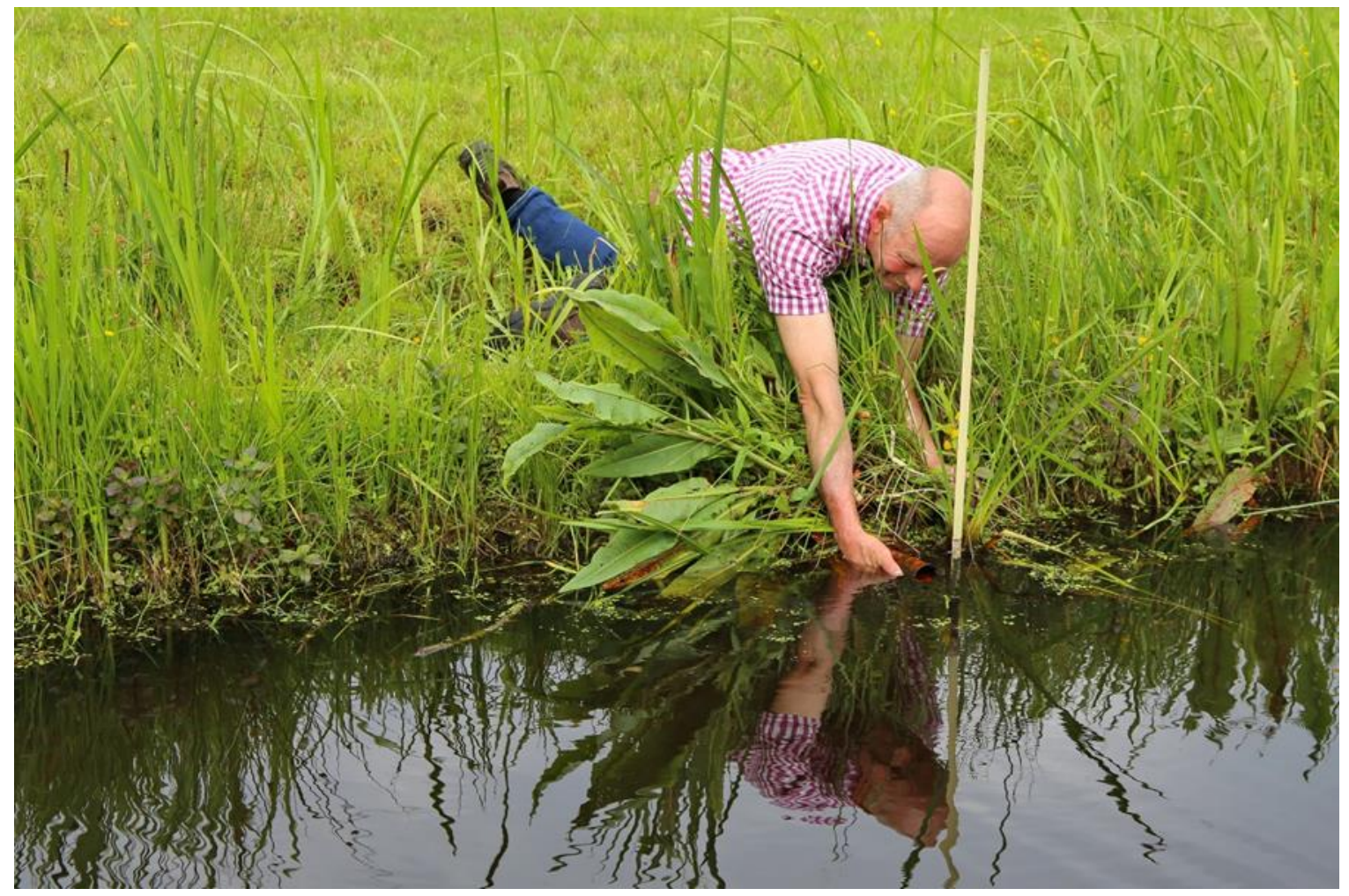

Figuur 1. Onderwaterdrain op 70 à $75 \mathrm{~cm}$ beneden maaiveld, ten minste $15 \mathrm{~cm}$ onder het slootpeil voor het aan- en afvoeren van water in de bodem onder grasland.

De aanleiding voor het toepassen van onderwaterdrains is dat veenbodems een relatief slechte horizontale doorlatendheid ( $\mathrm{k}$-waarde) hebben, waardoor het watertransport in de bodem aanzienlijk geremd wordt. Doordat hemelwater via de bodem zeer traag wordt afgevoerd stijgt bij een neerslagoverschot (neerslag groter dan verdamping) de grondwaterstand snel tot in het maaiveld. Het aanleggen van greppels bevordert de oppervlakkige afvoer van water, zodat minder water via de bodem afgevoerd hoeft te worden. Een relatief nauwe slootafstand zorgt ervoor dat het grondwater beneden het maaiveld blijft. Omgekeerd is de infiltratie van water uit de sloot in de bodem ook beperkt. Dit verlaagt de grondwaterstand bij een neerslagtekort (verdamping groter dan neerslag). De mate van doorlatendheid verschilt per type veengrond. Door het toepassen van onderwaterdrains wordt de horizontale bodemweerstand gemakkelijker overbrugt, waardoor de infiltratie vanuit de sloot en de drainage naar de sloot toeneemt. De aanleg van onderwaterdrains en het gewenste nivellerende effect op de gemiddelde winter- en zomergrondwaterstand is geïllustreerd in Figuur 2 . 


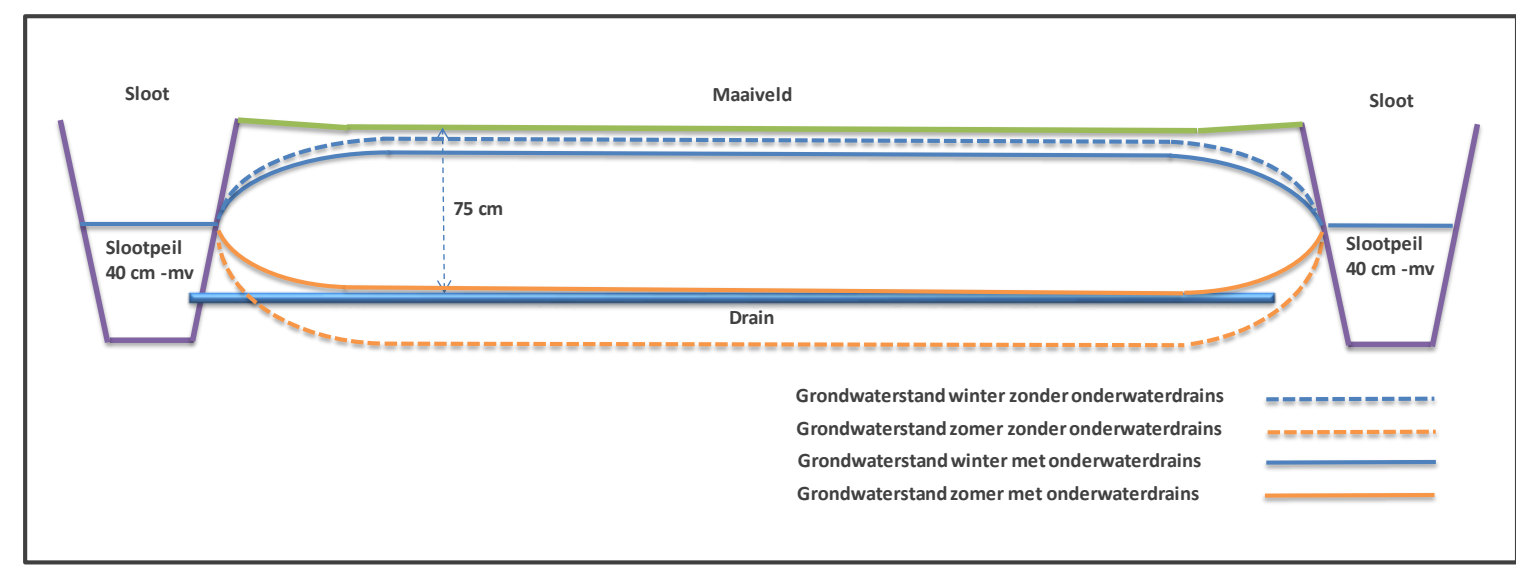

Figuur 2. Dwarsdoorsnede van een perceel en belendende sloten met een gemiddelde winter- en zomergrondwaterstand met en zonder onderwaterdrains ter illustratie van het gewenste nivellerende effect van onderwaterdrains op de grondwaterstand.

Het toepassen van onderwaterdrains in het westelijk veenweidegebied (voornamelijk mesotrofe ondergrond) had een significant vlakker grondwaterstandsverloop tot gevolg (Hoving et al. 2008, 2013, 2015; Van de Akker et al., 2013). Het effect op de grondwaterstand is daarbij erg afhankelijk van de hoogte van het slootpeil (Hoving et al. 2008). Een hoog slootpeil bevordert de infiltratie en een laag slootpeil bevordert de drainage. Dit betekent dat voor een optimale werking van de drains het slootpeil gevarieerd zou moeten kunnen worden afhankelijk van het neerslagbeeld.

Als tweede stap is zodoende gekeken hoe het effect op het verminderen van maaivelddaling versterkt kan worden door middel van een hoger zomerpeil en dynamisch slootpeilbeheer. Dit betekende dat in het groeiseizoen hogere slootpeilen gehanteerd werden om de infiltratie van oppervlaktewater in de bodem te bevorderen. Het toepassen van een zomer- en winterpeil komt tegemoet aan de grotere watervraag in de zomer, aangezien gemiddeld in het winterhalfjaar sprake is van een neerslagoverschot en in de zomer van een neerslagtekort. Het effect hiervan op de werking van onderwaterdrains is onderzocht in polder Zeevang (Hoving et al., 2015). Daarbij werd in het winterhalfjaar een slootpeil van $60 \mathrm{~cm}$ beneden maaiveld (onderbemaling) en in de zomer een slootpeil van $40 \mathrm{~cm}$ (boezempeil) gehanteerd. Ook in dit onderzoek hadden onderwaterdrains gemiddeld een significant vlakker grondwaterstandsverloop tot gevolg, echter tijdens natte perioden in het groeiseizoen leidden onderwaterdrains bij het hogere zomerpeil niet tot extra waterafvoer. Het aantal werkbare dagen met voldoende draagkracht was in de gedraineerde situatie zelfs kleiner dan in de ongedraineerde situatie. Bij een lager slootpeil van $60 \mathrm{~cm}$ beneden maaiveld in de zomer werd wel extra water met onderwaterdrains afgevoerd. Voor melkveehouders is een vermindering van gebruiksbeperkingen van grasland een belangrijke voorwaarde om te kunnen investeren in onderwaterdrains. Vooral extra weidegang leidt tot een reductie van de kosten (Van den Pol-van Dasselaar et al., 2013).

In een onderzoek op KTC Zegveld is in 2011 tot en met 2012 een vorm van dynamisch peilbeheer toegepast (Hoving et al., 2013), om te zien of het watermanagement bij toepassing van onderwaterdrains verder verfijnd kon worden. Daarbij werd als basis in het groeiseizoen een hoog slootpeil gehanteerd en werd alleen bij het gebruik van de betreffende percelen het peil verlaagd. Het onderzoek toonde aan dat op deze manier de grondwaterstand op een relatief hoog peil gehouden kan worden. In de loop van het onderzoek bleek het echter veel praktischer om het slootpeil te sturen op basis van de actuele grondwaterstand. Daarbij worden hoge slootpeilen gehanteerd op het moment dat het droog is en de grondwaterstand daalt (neerslagtekort) en worden lage slootpeilen gehanteerd op het moment dat het nat is en de grondwaterstand stijgt (neerslagoverschot). Het aantal peilwisselingen is hierdoor veel geringer dan wanneer ook rekening wordt gehouden met het gebruik van percelen. Een dynamisch slootpeilbeheer heeft echter als belangrijk nadeel dat het de stabiliteit van de slootkanten aantast en dat wisselende waterpeilen niet bevorderlijk zijn voor de ecologie van de sloot. Het zou dus mooi zijn als een vorm van dynamisch peilbeheer uitgevoerd kan worden onafhankelijk van het slootpeil. 
Als derde stap in de toepassing van onderwaterdrains is de toepassing van pompgestuurde onderwaterdrains onderzocht (resultaten voorliggend rapport). Hierbij wordt gebruik gemaakt van een waterreservoir waar de drainbuizen op aangesloten worden. De drains staan bij deze toepassing niet meer rechtstreeks in verbinding met het oppervlaktewater maar komen samen in een waterreservoir. Het reservoir wordt tussen de drains en de sloot geplaatst en met een pomp kan in het reservoir de gewenste ontwateringsbasis gerealiseerd worden onafhankelijk van het slootpeil. Met een relatief laag en hoog peil kan respectievelijk de drainerende en infiltrerende werking sterk vergroot worden. De aanleg van pompgestuurde onderwaterdrains is geïllustreerd in Figuur 3.

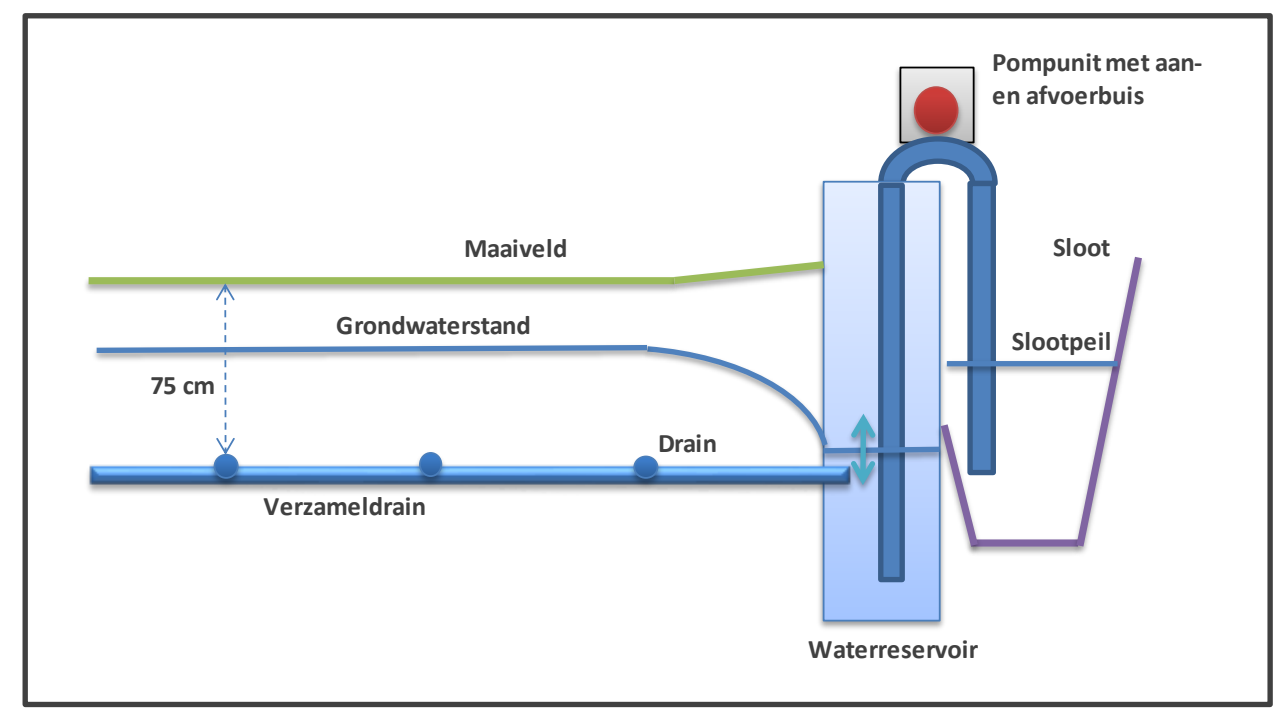

Figuur 3. Dwarsdoorsnede van een perceel met pompgestuurde onderwaterdrains waarbij in het waterreservoir de ontwateringsbasis geregeld wordt.

De aansturing van de pomp gebeurt op basis van de actuele grondwaterstand en de weersverwachting. Een systeem voor aansturing is binnen het onderzoek verder geconcretiseerd. Een groot voordeel van het gebruik van een waterreservoir is dat de buisdrains niet meer in de sloot uitkomen en dus ook niet meer beschadigd kunnen raken bij slootonderhoud of verstopt kunnen raken door instroming van bagger of andere verontreinigingen. Een negatief gevolg is echter, dat wanneer wel ergens in het systeem een verstopping optreedt, deze lastiger te verhelpen is.

\subsection{Grasopbrengst en ruweiwit}

De grasopbrengsten die in de periode van 2004 tot en met 2014 in veldexperimenten met onderwaterdrains zijn gemeten, zijn geanalyseerd om te zien wat het effect is van onderwaterdrains op de drogestofopbrengst en stikstofopbrengst op jaarbasis en het gemiddelde verloop van het ruweiwitgehalte gedurende het groeiseizoen. De dataset is niet geheel gebalanceerd vanwege de missende N-analyses voor 2005 en 2007 (laag slootpeil, onderwaterdrains), 2008 (hoog slootpeil, onderwaterdrains) en 2013 en 2014 (hoog slootpeil, geen onderwaterdrains) en een verschil in proefveldlocaties tussen de jaren. Zodoende kon geen statistische toets uitgevoerd worden. Een verschil in resultaten geeft dus alleen een indicatie, dat behandelingen al of niet tot een verschillend resultaat leiden. De bemestingsniveaus voor stikstof waren overigens wel voor elke proef gelijk. In elke proef werd hetzelfde bemestingsregime gehanteerd, zoals dat ook in het onderzoek dat in het onderliggende rapport staat beschreven (zie Tabel 5). De stikstofgift voor de bemeste objecten (N1) bedroeg $210 \mathrm{~kg} \mathrm{~N}$ per ha per jaar. In de meeste proeven lagen ook onbemeste veldjes (N0) om de hoeveelheid depositie en stikstoflevering door de bodem (als gevolg van de mineralisatie van organische stof) te kunnen kwantificeren.

Een vermindering van de veenafbraak door het toepassen van onderwaterdrains leidt tot minder stikstofmineralisatie en daardoor in principe tot een lagere opbrengst. De resultaten van het hoge peil 
met een drooglegging van $20 \mathrm{~cm}$ beneden maaiveld en het lagere peil met een drooglegging van 55 $\mathrm{cm}$ beneden maaiveld met en zonder onderwaterdrains staan in Tabel 1.

Tabel 1. Depositie en mineralisatie, jaaropbrengsten en ruw-eiwitgehalte bij een hoog en een laag slootpeil van respectievelijk 20 en $55 \mathrm{~cm}$ beneden maaiveld. Gemiddelde en standaardafwijking voor de jaren 2004 tot en met 2012 voor $20 \mathrm{~cm}$ beneden maaiveld (exclusief 2008) en 2004 tot en met 2014 voor $55 \mathrm{~cm}$ beneden maaiveld (exclusief 2005 en 2007).

\begin{tabular}{|c|c|c|c|c|c|c|}
\hline \multirow[t]{2}{*}{ Jaar } & \multicolumn{3}{|c|}{$\begin{array}{c}\text { Hoog slootpeil } \\
\text { (20 cm beneden maaiveld) }\end{array}$} & \multicolumn{3}{|c|}{$\begin{array}{c}\text { Laag slootpeil } \\
\text { ( } 55 \mathrm{~cm} \text { beneden maaiveld) }\end{array}$} \\
\hline & $\begin{array}{l}\text { Depositie en } \\
\text { mineralisatie } \\
(\mathrm{kg} \mathrm{N} / \mathrm{ha})\end{array}$ & $\begin{array}{l}\text { Opbrengst } \\
\text { (kg ds) }\end{array}$ & $\begin{array}{l}\text { Ruw eiwitgehalte } \\
(\mathrm{g} / \mathrm{kg})\end{array}$ & $\begin{array}{l}\text { Depositie en } \\
\text { mineralisatie } \\
\text { (kg N/ha) }\end{array}$ & $\begin{array}{l}\text { Opbrengst } \\
\text { (kg dm) }\end{array}$ & $\begin{array}{l}\text { Ruw eiwitgehalte } \\
(\mathrm{g} / \mathrm{kg})\end{array}$ \\
\hline \multicolumn{7}{|c|}{ Geen onderwaterdrains } \\
\hline 2004 & 219 & 13173 & 172 & 252 & 13997 & 187 \\
\hline 2005 & 194 & 12592 & 171 & 295 & 14622 & 179 \\
\hline 2006 & 183 & 11725 & 191 & 295 & 13118 & 202 \\
\hline 2007 & 241 & 12447 & 175 & 298 & 13299 & 163 \\
\hline 2008 & 251 & 10082 & 200 & 261 & 12558 & 192 \\
\hline 2011 & 253 & 12772 & 191 & 287 & 11149 & 212 \\
\hline 2012 & 226 & 12206 & 168 & 235 & 12343 & 192 \\
\hline 2013 & & & & 210 & 13024 & 185 \\
\hline 2014 & & & & 264 & 12733 & 185 \\
\hline Gemiddelde ${ }^{1)}$ & 219 & 12486 & 178 & 258 & 12703 & 194 \\
\hline Stdev ${ }^{1)}$ & 27 & 495 & 10 & 29 & 868 & 10 \\
\hline \multicolumn{7}{|c|}{ Onderwaterdrains } \\
\hline 2004 & 206 & 13174 & 161 & 300 & 15099 & 194 \\
\hline 2005 & 172 & 12034 & 165 & & & \\
\hline 2006 & 164 & 10221 & 184 & 277 & 12384 & 206 \\
\hline 2007 & 203 & 12036 & 170 & & & \\
\hline 2008 & & & & 274 & 12586 & 187 \\
\hline 2011 & 275 & 13002 & 187 & 304 & 10853 & 214 \\
\hline 2012 & 251 & 13109 & 169 & 268 & 11979 & 195 \\
\hline 2013 & & & & 221 & 12028 & 187 \\
\hline 2014 & & & & 265 & 12620 & 184 \\
\hline Gemiddelde & 212 & 12263 & 173 & 273 & 12507 & 195 \\
\hline Stdev & 44 & 1128 & 10 & 27 & 1291 & 11 \\
\hline
\end{tabular}

Hoewel, vanwege het verschil in aantal onderzoekjaren, de resultaten van het hoge en het lage slootpeil lastig te vergelijken zijn, lijken de drogestofopbrengsten, het totaal van depositie en mineralisatie en het ruw-eiwitgehalte bij het lagere peil in de meeste jaren hoger te zijn dan bij het hoge peil (uitgezonderd 2004, 2011 en 2012 in de gedraineerde situatie). De resultaten bevestigen dat door peilverlaging de productiviteit toeneemt, hetgeen vanuit de praktijk bekend is. Het toepassen van onderwaterdrains gaf bij het hoge peil gemiddeld een kleine verlaging van het totaal van depositie en mineralisatie, drogestofopbrengst en ruw-eiwitgehalte. Bij het lage peil was gemiddeld het totaal van depositie en mineralisatie hoger, was de drogestofopbrengst iets lager en was het ruweiwitgehalte vrijwel gelijk.

In de normen voor de mestwetgeving is het ureumgehalte van de melk een belangrijk gegeven, aangezien op basis van dit kengetal en het melkproductieniveau een differentie van excretienormen voor dierlijke mest plaatsvindt. Lagere ureumgehaltes leiden bij een overschot aan dierlijke mest tot lagere afzetkosten voor mest. Om het ureumgehalte niet te hoog te laten worden, is het van belang om grip te hebben op het ruw-eiwitgehalte van gras. Vooral op veengrond is dit lastig, omdat veen veel stikstof levert door mineralisatie van organische stof, zeker bij een diepere ontwatering. Verschillen tussen het verloop van het ruw-eiwitgehalte van gras tussen sneden bij verschillende slootpeilen en wel of geen toepassing van onderwaterdrains zijn in Figuur 4 inzichtelijk gemaakt. 


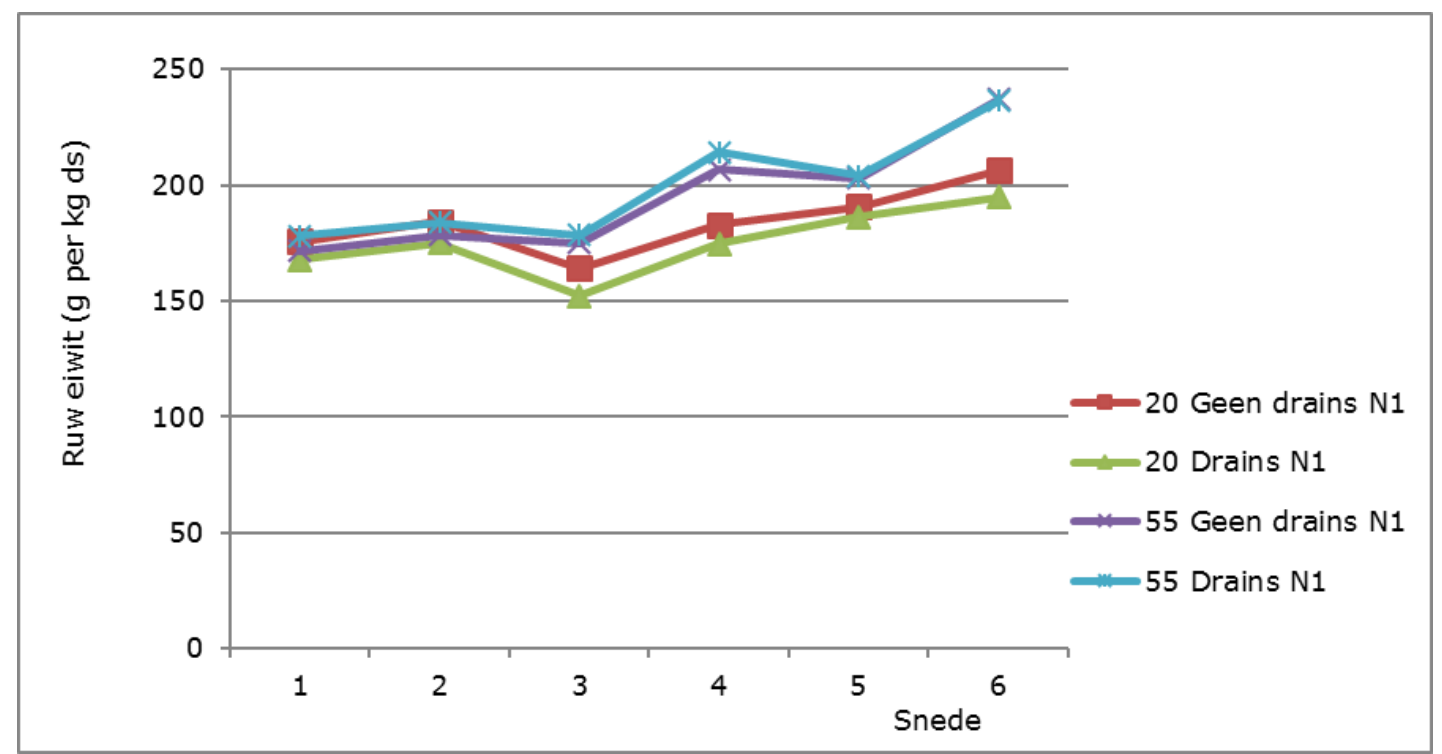

Figuur 4. Effect van drooglegging (20 en $55 \mathrm{~cm}$ beneden maaiveld) en wel en geen onderwaterdrains (drains) op het ruw-eiwitgehalte van het gras bij een stikstofjaargift van $210 \mathrm{~kg}$ per ha per jaar.

De resultaten in Figuur 4 laten zien dat de ruw-eiwitgehaltes in de loop van het jaar stijgen en dat deze stijging bij een drooglegging van $55 \mathrm{~cm}$ beneden maaiveld sterker is dan bij een $20 \mathrm{~cm}$ beneden maaiveld. Bij het hoge slootpeil lijken onderwaterdrains het ruw-eiwitgehalte verder te verlagen. De resultaten laten zien dat een forse vernatting nodig is om het eiwitgehalte substantieel naar beneden te brengen.

\subsection{Kosten en baten boer en maatschappij}

Om het toenemende verschil met hoogwaterzones (bebouwing en infrastructuur) te verminderen wordt het verminderen van maaivelddaling van landbouwgrond, zeker bij toepassing van onderbemaling, maatschappelijk steeds belangrijker. Het peilbeheer raakt steeds verder versnipperd, waardoor het peilbeheer wordt bemoeilijkt en de kosten hiervan toenemen. Hoogwaterzones vragen om relatief hoge slootpeilen gelijk aan het polderpeil of hoger. Daarentegen is vanuit de melkveehouderijsector, die het merendeel van het veenweideareaal in gebruik heeft, vernatting erg ongewenst omdat dit in natte perioden de draagkracht van de graszode verlaagt. Dit is nadelig voor het graslandgebruik en verhoogt de kosten waardoor het bedrijfsinkomen onder druk komt te staan (Hoving en De Vos, 2007). Het verkleinen van het risico op vernatting vraagt om relatief lage slootpeilen. Daartoe wordt in de meeste peilbesluiten een slootpeil van 50 à $60 \mathrm{~cm}$ beneden maaiveld toegestaan bij een vergunning voor onderbemaling.

Onderwaterdrains zorgen tijdens natte perioden voor extra waterafvoer waardoor de graszode minder nat wordt en sneller voldoende draagkracht heeft voor weidegang en berijding. Dit is overigens alleen het geval wanneer de drooglegging ten minste $40 \mathrm{~cm}$ beneden maaiveld bedraagt. Vooral extra dagen weidegang leidt tot een reductie van de kosten (Van den Pol-van Dasselaar et al., 2013). In Van den Akker et al., 2013 en Hoving et al., 2015 zijn door middel van een rekenvoorbeeld de kosten en baten van de aanleg van onderwaterdrains inzichtelijk gemaakt. In Tabel 2 is het rekenvoorbeeld geactualiseerd op basis van de huidige prijspeilen (KWIN 2018). 
Tabel 2. Jaarlijks economisch voordeel van onderwaterdrains ( $€ / h a)$ bij een drainafstand van $6 \mathrm{~m}$ op basis van de tarieven volgens KWIN (2018).

\begin{tabular}{|c|c|c|c|}
\hline Kosten & & & \\
\hline Investering onderwaterdrainage & 1800,00 & $(€ /$ ha $)$ & \\
\hline Jaarkosten $6,5 \%$ gedurende 20 jaar & & $(€ /$ ha $)$ & 117,00 \\
\hline \multicolumn{4}{|l|}{ Baten } \\
\hline Extra grasbenutting & 500 & (kg ds/ha) & \\
\hline Besparing kosten aankoop maïs & & $(€ /$ ha $)$ & 81,43 \\
\hline Voordeel voederwaarde weidegras & & $(€ /$ ha $)$ & 19,82 \\
\hline Voordeel extra weidedagen & 30 & $(€ /$ ha $)$ & 67,85 \\
\hline Totaal voordeel & & $(€ /$ ha $)$ & 171,00 \\
\hline Verschil & & $(€ /$ ha $)$ & 54,00 \\
\hline
\end{tabular}

\subsection{Maaivelddaling en $\mathrm{CO}_{2}$-emissie}

De $\mathrm{CO}_{2}$-emissie van veengronden in landbouwkundig gebruik bedraagt ca. 20 ton per ha per jaar (Van den Akker en Hendriks, 2014). De totale $\mathrm{CO}_{2}$-emissie in Nederland door oxidatie van veengronden is ca. 4,2 Mton per jaar, waarbij nog 0,4 Mton $\mathrm{CO}_{2}$-equivalent aan $\mathrm{N}_{2} \mathrm{O}$-emissie kan worden toegevoegd. In totaal is dit ca. 2,5\% van de nationale antropogene $\mathrm{CO}_{2}$-emissie. Net als de maaivelddaling dreigt de $\mathrm{CO}_{2}$-emissie eind deze eeuw bijna te verdubbelen (Van den Akker en Hendriks, 2014). Om de $\mathrm{CO}_{2}$ emissiereducties die door de Europese Unie worden opgelegd te halen wordt het beperken van veenoxidatie een steeds urgentere zaak.

In Hoving et al., (2008) is gesteld dat de drooglegging minimaal 35 à $40 \mathrm{~cm}$ moet zijn (hoger slootpeil) om met onderwaterdrains de maaivelddaling substantieel met $50 \%$ te verminderen ten opzichte van de landbouwkundig gewenste drooglegging. Dit gaat echter ten koste van de landbouwkundige baten. Voor melkveehouders is een vermindering van beperkingen voor graslandgebruik een belangrijke voorwaarde om te gaan investeren in onderwaterdrains. Vooral extra dagen weidegang leidt tot een reductie van de kosten (Van den Pol-van Dasselaar et al., 2013 en Van den Akker et al., 2013).

In 2003 zijn in het najaar op de toenmalige proefboerderij Zegveld (nu KTC Zegveld) de eerste proeven met onderwaterdrains gestart. Op de proefboerderij liep al vanaf 1969 een monitoring van de maaivelddaling, waarbij het effect van een onderbemaling (drooglegging van ca. $60 \mathrm{~cm}$ beneden maaiveld) werd vergeleken met een polderpeil (drooglegging van $15-25 \mathrm{~cm}$ beneden maaiveld). Uit deze monitoring bleek dat door de onderbemaling de maaivelddaling ongeveer was verdubbeld (Beuving en Van den Akker, 1996). Dit bleek ook uit een hoogtemeting van alle percelen in het voorjaar van 2003 waarbij de verkregen hoogtekaart werd afgetrokken van een hoogtekaart uit 1966 (Van den Akker, 2005). Wat diepere droogleggingen tot ca. $60 \mathrm{~cm}$ komen in het westelijk veenweidegebied veel voor. Rond het jaar 2000 werd steeds duidelijker dat de resulterende maaivelddalingen van soms meer dan $1 \mathrm{~cm}$ per jaar in toenemende mate een probleem zouden worden. De voor de hand liggende oplossing van peilverhogingen zou echter resulteren in een onrendabelere melkveehouderij en zou deze erg kwetsbaar maken voor nattere jaren. De weerstand vanuit de melkveehouderij tegen geopperde slootpeilverhogingen was daardoor fel en effectief. Dit was de reden om als alternatief voor de peilverhogingen de toepassing van onderwaterdrains aan te dragen, met als doel om in de zomer door de verbeterde infiltratie de grondwaterstanden op hetzelfde niveau te brengen als bij percelen met een hoog slootpeil. Daarmee zouden de maaivelddalingen naar verwachting ongeveer overeenkomen met percelen met een hoog peil en dus worden gehalveerd. In de nattere perioden (winter) zou de verbeterde drainage zorgen voor betere bedrijfsomstandigheden, waardoor onderwaterdrains aantrekkelijk zouden worden voor de melkveehouderij.

Monitoring van maaivelddaling bleek lastig te financieren, maar kon de laatste 15 jaar uiteindelijk met behulp van verschillende projecten redelijk worden bijgehouden. In 2018 zal een overzicht worden gerapporteerd (Van den Akker et al., 2018 - in voorbereiding). Deze paragraaf is op dit 
conceptrapport gebaseerd. De eerste resultaten laten zien dat onderwaterdrains de maaivelddaling met ongeveer 50 procent kunnen reduceren doordat de grondwaterstand in droge perioden in het zomerhalfjaar minder ver daalt (Van den Akker et al., 2007, 2010, 2012 en 2017). De langste monitoring naar het effect van onderwaterdrains op de maaivelddaling loopt in Zegveld bij o.a. de percelen 3 en 13. Bij deze percelen zijn in het najaar van 2003 onderwaterdrains aangelegd op $4 \mathrm{~m}$ onderlinge afstand. Perceel 3 heeft een drooglegging van $55 \mathrm{~cm}$ en perceel 13 van slechts $20 \mathrm{~cm}$. Op perceel 3 blijkt de maaivelddaling over de periode 2004 - 2015 door de toepassing van onderwaterdrains met 50\% te zijn gereduceerd (Van den Akker en Hendriks, 2017) en op perceel 13 was de reductie in de periode 2004 - 2017 zelfs ca $65 \%$.

Door de hogere grondwaterstand en de door de infiltratie nattere toestand boven de grondwaterstand treedt zuurstof minder ver in de bodem, waardoor de veenafbraak reduceert. Maaivelddaling wordt voor een groot gedeelte door oxidatie (veenafbraak) bepaald. Grønland et al (2008) geven aan dat ongeveer $50 \%$ van de maaivelddaling aan veenafbraak kan worden toegeschreven. Eggelsmann (1976) komt op 70\% en Schothorst (1977) op 85\% voor veenweiden die al eeuwen in landbouwkundig gebruik zijn. De veenafbraak veroorzaakt naast maaivelddaling ook $\mathrm{CO}_{2}$-emissies. Daardoor zijn maaivelddaling en $\mathrm{CO}_{2}$-emissies sterk aan elkaar gerelateerd. Schothorst $(1977,1982)$ relateerde reeds de afbraak en verlies van organische stof aan de maaivelddaling. Om het aandeel van de afbraak in de maaivelddaling te bepalen beschouwde hij de relatieve toename van de minerale delen in de bovenste bodemlagen ten opzichte van de oorspronkelijke massa aan minerale delen, zoals deze kan worden bepaald in de diepere veenlagen. Ter controle relateerde Schothorst (1977, 1982) het verlies aan organische stof met de hoeveelheid vrijgekomen hoeveelheid stikstof door de veenafbraak (stikstofmineralisatie). Een soortgelijke aanpak is ook uitgevoerd door Grønland et al (2008) voor Noorse veengronden in agrarisch gebruik. Bovendien vergeleek Grønland et al (2008) de bepaalde $\mathrm{CO}_{2}$-emissies uit maaivelddaling en uit stikstofmineralisatie met $\mathrm{CO}_{2}$-emissies gemeten met de gesloten-kamermethode, met als conclusie dat deze drie bepalingsmethoden goed op elkaar aansluiten. Van den Akker et al $(2007,2008)$ geven aan dat een maaivelddaling van $1 \mathrm{~mm}$ per jaar overeen komt met een $\mathrm{CO}_{2}$-emissie van 2,26 ton $\mathrm{CO}_{2} \cdot \mathrm{ha}^{-1} \cdot \mathrm{jr}^{-1}$. Dit is gebaseerd op de redenering dat indien de slootpeilen voortdurend worden aangepast aan de maaivelddaling er op den duur over een middellange termijn van bijvoorbeeld 20 jaar min of meer een evenwicht ontstaat in de hoeveelheid organische stof in de eerste meter van het veenbodemprofiel. Bij een jaarlijkse maaivelddaling van $1 \mathrm{~cm}$ en (theoretisch) jaarlijkse aanpassing van het slootpeil met $1 \mathrm{~cm}$ wordt als het ware steeds $1 \mathrm{~cm}$ vers veen van de ondergrond ontsloten. Uitgaande van een gemiddelde dichtheid van het veen op 1 meter diepte, zoals in Zegveld, is de hoeveelheid organische stof in die centimeter vers veen per hectare 11,2 ton waarin 6,16 ton $C$. Uitgaande van een evenwicht aan $C$ in de eerste meter veen wordt eenzelfde hoeveelheid $\mathrm{C}$ door biologische afbraak in het geaereerde deel van het veenprofiel omgezet in 22,6 ton $\mathrm{CO}_{2}$ dat als emissie aan het maaiveld in de atmosfeer terechtkomt. Deze methode om uit de maaivelddaling de $\mathrm{CO}_{2}$-emissies te berekenen is door Couwenberg en Hooijer (2013) ook gebruikt voor tropische venen. Om aan te tonen dat de methode werkt zijn in dit artikel voor Europese venen een aantal $\mathrm{CO}_{2}$-emissies berekend uit de maaivelddaling vergeleken met emissies, zoals gemeten met gesloten kamers. Daarvoor is wat betreft de berekening van de $\mathrm{CO}_{2}$-emissies uit maaivelddaling data gebruikt van veengronden zonder dun kleidek uit Van den Akker et al. (2008).

Geconcludeerd werd dat de emissiewaarden goed bij elkaar pasten en dat door de totale verzameling van uit maaivelddaling berekende en direct gemeten $\mathrm{CO}_{2}$-emissies een goede regressielijn kon worden gefit (Couwenberg en Hooijer, 2013):

$$
\begin{aligned}
& y_{1}=-14,2 x ;\left(r^{2}=0,84 ; P<0,001\right) \\
& y_{2}=-52,1 x ;\left(r^{2}=0,84 ; P<0,001\right) \\
& \text { waarin } y_{1}=\text { de emissie in } \mathrm{t} \mathrm{ha}^{-1} \mathrm{j}^{-1} \\
& \mathrm{y}_{2}=\text { de emissie in } \mathrm{CO}_{2} \mathrm{ha}^{-1} \mathrm{j}^{-1} \\
& \mathrm{x}=\text { het jaargemiddelde slootpeil in } \mathrm{m}
\end{aligned}
$$

In vergelijking (1b) is de oorspronkelijke vergelijking (1a) omgezet naar tonnen $\mathrm{CO}_{2}$ per hectare per jaar. 
Door Van den Akker et al. (2007, 2008) zijn uit monitoringsdata aan maaivelddaling en slootpeilen en grondwaterstanden empirische relaties bepaald om de jaarlijkse maaivelddaling te berekenen uit slootpeilen (drooglegging) en kengetallen voor de grondwaterstand, zoals de GLG, gemiddelde zomergrondwaterstand of gemiddelde jaargrondwaterstand. Deze empirische relaties zijn in Kuikman et al (2005) gebruikt om de maaivelddaling van veengebieden in Nederland in kaart te brengen en deze vervolgens om te zetten in $\mathrm{CO}_{2}$-emissies om zo voor Nederland de totale $\mathrm{CO}_{2}$-emissie van veengronden in agrarisch gebruik te berekenen.

In onderstaande vergelijkingen (2), (3) en (4) zijn de oorspronkelijke vergelijkingen voor de relaties tussen maaivelddaling en drooglegging uit Van den Akker et al (2007) omgezet naar relaties tussen $\mathrm{CO}_{2}$-emissie en drooglegging, waarbij $1 \mathrm{~mm}$ maaivelddaling gelijk is gesteld aan een $\mathrm{CO}_{2}$-emissie van 2,26 ton $\mathrm{CO}_{2} \cdot \mathrm{ha}^{-1}$.

Bij veengronden zonder kleidek bepaald met een dataset met alleen de veengronden zonder kleidek:

$$
\begin{gathered}
y=43,52 x+1,40 ; R^{2}=0,84 \\
\text { waarin } y=\text { de emissie in } \mathrm{t} \mathrm{CO}_{2} \mathrm{ha}^{-1} \mathrm{j}^{-1} \\
\mathrm{x}=\text { drooglegging in } \mathrm{m}
\end{gathered}
$$

Bij veengronden zonder kleidek bepaald met een dataset met veengronden met en zonder kleidek:

$$
y=34,93 x+6,22 ; R^{2}=0,66
$$

Bij veengronden met dun kleidek $(<40 \mathrm{~cm}$ ) bepaald met een dataset met veengronden met en zonder kleidek:

$$
y=34,93 x-7,98 ; R^{2}=0,66
$$

Door van den Akker et al (2007) wordt aangegeven dat veenoxidatie veel beter aan de diepste grondwaterstanden in de zomerperiode kan worden gerelateerd dan aan slootpeilen. Aan het einde van de zomer zijn in het algemeen niet alleen de grondwaterstanden op zijn diepst maar is de grond ook op zijn droogst met de meeste en diepste krimpscheuren waardoor zuurstof diep in het profiel kan dringen en zijn bovendien de bodemtemperaturen op zijn hoogst. De potentiele afbraaksnelheid van veen neemt bij toenemende bodemtemperatuur snel toe. Met een factor $\mathrm{Q}_{10}$ wordt aangegeven hoeveel de potentiele afbraak toeneemt bij een stijging van $10^{\circ} \mathrm{C}$. Hendriks en Vermeulen (1997) en Vermeulen en Hendriks (1996) vonden voor Nederlandse veengronden in het temperatuurtraject van 0 - $10{ }^{\circ} \mathrm{C}$ een $\mathrm{Q}_{10}$-waarde van 3,0 - 5,6 en in het traject van $10-20{ }^{\circ} \mathrm{C} \mathrm{Q}_{10}$-waarden van 2,4 - 3,6. De in de literatuur vaak vermelde $\mathrm{Q}_{10}$-waarden van 2 - 3 gelden waarschijnlijk voor temperaturen $>20^{\circ} \mathrm{C}$. Dit zijn potentiële afbraaksnelheden, die echter alleen kunnen worden gerealiseerd als er zuurstof bij het veen kan komen. Aan het einde van de zomer met in het algemeen een combinatie van diepste grondwaterstanden en hoogste bodemtemperaturen zijn de omstandigheden voor vertering daardoor optimaal. Natuurlijk wordt de grondwaterstand sterk bepaald door de slootpeilen, de drijvende kracht achter de mate waarmee de sloot kan draineren of infiltreren. Daarnaast spelen echter ook verdamping, neerslag, doorlatendheden, slootafstanden, kwel en wegzijging een grote rol. Door al deze invloeden kunnen de verschillen in maaivelddalingen bij eenzelfde slootpeil groot zijn. Bij beschouwing van de diepste grondwaterstanden zijn al deze invloeden en het slootpeil verdisconteerd en wordt bovendien indirect rekening gehouden met het effect van de bodemtemperatuur door de in het algemeen aanwezige correlatie tussen grondwaterstand en bodemtemperatuur (in de periode dat de grondwaterstanden diep zijn, zijn de bodemtemperaturen ook hoog). Daarom wordt aangeraden om bij de berekening van maaivelddalingen en $\mathrm{CO}_{2}$-emissies gebruik te maken van relaties met de diepste grondwaterstanden, zoals deze door bijvoorbeeld de GLG worden gekenmerkt, in plaats van slootpeilen en jaargemiddelde grondwaterstanden.

In onderstaande vergelijkingen (5), (6) en (7) zijn de oorspronkelijke vergelijkingen voor de relaties tussen maaivelddaling en GLG uit Van den Akker et al (2007) omgezet naar relaties tussen $\mathrm{CO}_{2}$ emissie en GLG, waarbij $1 \mathrm{~mm}$ maaivelddaling gelijk is gesteld aan een $\mathrm{CO}_{2}$-emissie van 2,26 ton $\mathrm{CO}_{2} \cdot \mathrm{ha}^{-1}$. 
Bij veengronden zonder kleidek bepaald met een dataset met alleen de veengronden zonder kleidek:

$$
\begin{aligned}
& \text { y }=61,72 \text { GLG - 19,95; } \mathrm{r}^{2}=0,98 \\
& \text { waarin } y=\text { de emissie in } \mathrm{t} \mathrm{CO}_{2} \mathrm{ha}^{-1} \mathrm{j}^{-1} \\
& \text { GLG = Gemiddeld Laagste Grondwaterstand in } \mathrm{m}
\end{aligned}
$$

Bij veengronden zonder kleidek bepaald met een dataset met veengronden met en zonder kleidek:

$$
y=53,19 \text { GLG }-15,10 ; r^{2}=0,61
$$

Bij veengronden met dun kleidek $(<40 \mathrm{~cm}$ ) bepaald met een dataset met veengronden met en zonder kleidek:

$$
y=53,19 \text { GLG }-23,66 ; r^{2}=0,61
$$

Bij de toepassing van onderwaterdrains kunnen de empirische vergelijkingen (1) t/m (4), waarbij de $\mathrm{CO}_{2}$-emissies worden gerelateerd aan het slootpeil, niet worden gebruikt omdat immers het grondwatersysteem drastisch is veranderd en bij dezelfde drooglegging meer water infiltreert en de grondwaterstanden minder diep zullen uitzakken. Voor de empirische vergelijkingen (5) t/m (7), waarin de GLG de verklarende grootheid is, geldt dit in ieder geval in veel geringere mate, omdat de GLG direct samenhangt met de grondwaterstandsbewegingen en de diepte tot waar zuurstof in de grond kan dringen. Toch zal daarbij moeten worden bedacht dat de onderwaterdrains niet alleen infiltreren maar ook draineren, zodat bijvoorbeeld naar verwachting de GHG (Gemiddeld Hoogste Grondwaterstand) dieper wordt, zodat de bovengrond en zodelaag gemiddeld minder vaak verzadigd zal zijn en daardoor wellicht meer veenoxidatie kent. Anderzijds zal door de voortdurende verbeterde infiltratie de bodemlaag direct boven de grondwaterstand natter blijven zodat daar de zuurstofvoorziening weer slechter is (Van den Akker et al., 2018- in voorbereiding). Uiteindelijk zullen nieuwe empirische relaties vastgesteld moeten worden, maar tot dan kunnen de vergelijkingen (5) t/m (7) goed worden gebruikt.

Aangezien de metingen in Zegveld hebben plaatsgevonden, kunnen het beste de vergelijkingen voor alleen veengronden zonder dun kleidek worden gebruikt. Voor de maaivelddaling is dat onderstaande vergelijking (8) (uit Van den Akker et al., 2007). Deze geldt dus voor veengronden zonder kleidek bepaald met een dataset met alleen de veengronden zonder kleidek:

$$
\begin{aligned}
& \mathrm{y}=27,31 \mathrm{GLG}-8,83 ; \mathrm{R}^{2}=0,98 \\
& \text { waarin } \mathrm{y}=\text { de maaivelddaling in } \mathrm{mm} \text { per jaar } \\
& \quad \mathrm{GLG}=\text { Gemiddeld Laagste Grondwaterstand in } \mathrm{m}
\end{aligned}
$$

Voor de $\mathrm{CO}_{2}$-emissie kan dan het beste vergelijking (5) worden gebruikt. 


\section{Materiaal en methode}

\subsection{Bodemkarakteristiek proeflocatie}

Ter voorbereiding van het onderzoek is een bodeminventarisatie uitgevoerd op proefperceel 13, 14, 15 en 16 om te zien of de percelen voor wat betreft bodem en grondwaterdynamiek vergelijkbaar en voldoende homogeen waren. De betreffende proefpercelen liggen op een koopveengrond met een grondwatertrap (Gt) II, waarbij de gemiddeld hoogste grondwaterstand (GHG) hoger is dan $40 \mathrm{~cm}$ beneden maaiveld en de gemiddeld laagste grondwaterstand (GLG) 50 à $80 \mathrm{~cm}$ beneden maaiveld bedraagt. Tot gemiddeld 6,4 m beneden maaiveld komt hoofdzakelijk veen voor dat overgaat in matig fijn zand. Voor het bepalen van de drainafstand is de horizontale bodemweerstand bepaald door middel van de zogenaamde boorgatmethode.

\section{Boorgatmetingen}

Op 14 maart 2016 zijn op 4 percelen, telkens op 2 locaties boorgatmetingen uitgevoerd. De locaties op KTC Zegveld waar het boorgatenonderzoek is uitgevoerd staan in Figuur 5. Om de uitgangsgrondwaterstand te bepalen zijn vooraf op de locaties geperforeerde peilfilters geplaatst. Bij elke locatie zijn twee boorgaten gemaakt waarin een of twee metingen zijn uitgevoerd. Er is steeds gemeten met een geperforeerd filter zodat de vlotter vrij kon bewegen.

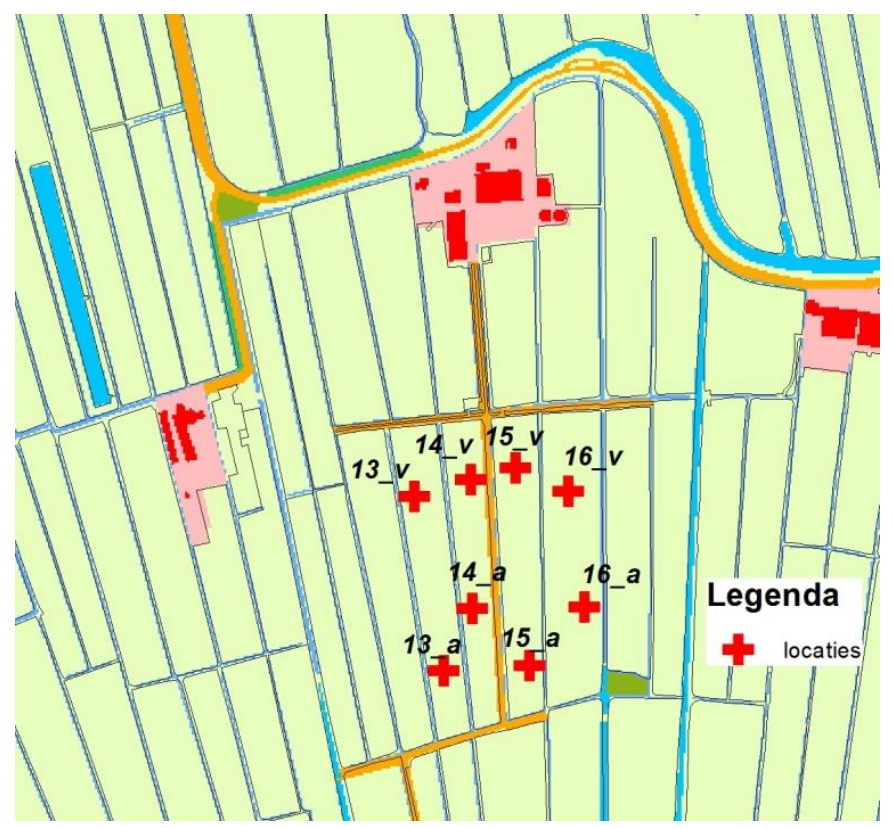

Figuur 5. Locaties boorgatenonderzoek KTC Zegveld op 14 maart 2016.

De resultaten van de boorgatmetingen voor wat betreft de horizontale doorlatendheid van de bodem (k-waarde) staan in Tabel 3. 
Tabel 3. Gemiddelde horizontale doorlatendheid van de bodem (k-waarde) en de coördinaten per meetlocatie.

\begin{tabular}{|c|c|c|c|}
\hline \multirow[t]{2}{*}{ Locatie } & \multirow[t]{2}{*}{ Gemiddeld } & \multicolumn{2}{|c|}{ Coördinaten (m) } \\
\hline & & x-coördinaat & y-coördinaat \\
\hline 13_a & 0.15 & 117384 & 460927 \\
\hline 13_v & 0.04 & 117352 & 461120 \\
\hline 14_a & 0.20 & 117416 & 460996 \\
\hline 14_v & 0.07 & 117414 & 461139 \\
\hline 15_a & 0.12 & 117479 & 460932 \\
\hline 15_v & 0.22 & 117464 & 461152 \\
\hline 16_a & 0.46 & 117540 & 460997 \\
\hline 16_v & 0.47 & 117522 & 461126 \\
\hline Gemiddeld & 0.22 & & \\
\hline Mediaan & 0.17 & & \\
\hline
\end{tabular}

Tussen de meetlocaties blijkt dat de variatie in k-waarden relatief groot is. Op perceel 16 werden de grootste k-waarden gemeten, ca 0,46 m per dag. De laagste waarden zijn gevonden aan de noordzijde van perceel 13 en 14, respectievelijk 0,04 en 0,07 m per dag. Voor de overige locaties varieert de k-waarde tussen 0,11 en 0,22 $\mathrm{m}$ per dag. Door de variatie in k-waarden kan de infiltratie per proefperceel verschillen. Uitgaande van de mediane k-waarde is de drainafstand van $6 \mathrm{~m}$ net niet voldoende om bij een uitholling van $10 \mathrm{~cm}$ een infiltratie van $3 \mathrm{~m}$ per dag te realiseren. Als de eis met betrekking tot de uitholling op 0,15 m gesteld wordt, dan is $6 \mathrm{~m}$ wel voldoende. Door variatie in kwaarden verschilt mogelijk de infiltratie per locatie.

De drainage is aangelegd met een drainafstand van $6 \mathrm{~m}$ met een draindiepte van $65-70 \mathrm{~cm}$ beneden maaiveld op de proefpercelen met een hoog slootpeil (perceel 13 en 14) en een draindiepte van 70-75 $\mathrm{cm}$ beneden maaiveld op de percelen met een laag slootpeil (perceel 15 en 16).

Om het effect van eventuele fouten in de boorgatwaarnemingen op de k-waarde te onderzoeken is een beperkte gevoeligheidsanalyse uitgevoerd. De mediane k-waarden van de gevoeligheidsanalyse staan in Bijlage 1, evenals de uitgangspunten van het drainageadvies.

\subsection{Proefopzet}

\section{Behandelingen}

Op KTC Zegveld is in het voorjaar van 2016 een veldproef met twee toepassingen van onderwaterdrains aangelegd op perceel 13, 14, 15 en 16. In de proef werd de toepassing van pompgestuurde onderwaterdrains binnen een perceel vergeleken met gangbare onderwaterdrains op de sloot en een uitgangssituatie zonder onderwaterdrains. De proef is uitgevoerd in tweevoud bij een vast hoog (perceel 13 en 14) en een vast laag slootpeilregime (perceel 15 en 16). Per slootpeilregime werd dus gebruik gemaakt van twee proefpercelen.

Idealiter zouden de k-waarden binnen de percelen gelijk moeten zijn, echter dit was niet het geval (zie vorige paragraaf) en is in de praktijk ook lastig te realiseren gezien de variatie tussen en binnen percelen. De situering van de twee peilniveaus en de aanwezigheid van elektriciteit maakten dat de betreffende percelen het meest geschikt waren voor het uitvoeren van het onderzoek. Vooral de relatief lage k-waarden aan de noordzijde van perceel 13 en 14 en de zuidzijde van perceel 15 zouden beperkend kunnen zijn. Op perceel 13 en 14 zijn de pompgestuurde onderwaterdrains aangelegd aan de noordzijde, dus het gedeelte met de lage k-waarden. Aangezien met de pompvoorziening in potentie de werking van de onderwaterdrains vergroot, waren de lage k-waarden waarschijnlijk minder beperkend. Op perceel 15 waren de relatief lage k-waarden in het nadeel van de onderwaterdrains op de sloot.

Op de proefpercelen lagen opbrengstveldjes voor het bepalen van de grasopbrengst. De grasopbrengsten werden bepaald om verschil in stikstoflevering door de bodem tussen behandelingen 
vast te stellen en om te zien in hoeverre dit effect gecompenseerd werd door bemesting. Daarbij werd onderscheid gemaakt in twee niveaus van stikstofbemesting, namelijk geen stikstofbemesting (N0) en wel stikstofbemesting volgens praktijkniveau (N1).

Samengevat waren de behandelingen in de veldproef als volgt:

Hoofdbehandelingen

1. Vast hoog slootpeil, drooglegging van $20 \mathrm{~cm}$ beneden maaiveld (perceel 13 en 14)

2. Vast laag slootpeil, drooglegging van $55 \mathrm{~cm}$ beneden maaiveld (perceel 15 en 16)

Subbehandelingen (1)

a) Geen onderwaterdrains

b) Onderwaterdrains op de sloot

c) Onderwaterdrains met pompaansturing

Subbehandelingen (2)

a) Geen stikstofbemesting (NO)

b) Wel stikstofbemesting (N1)

\section{Inrichting proefpercelen}

De proefpercelen zijn in de lengterichting gedraineerd met een drainafstand van $6 \mathrm{~m}$. De drie drainbehandelingen werden gerealiseerd door in het midden van de percelen de drains op twee plaatsen te onderbreken. Tussen de onderbrekingen werkten de drains niet. Dit betrof de behandeling Geen onderwaterdrains. De drains aan de zuidzijde van de percelen waren via een verzameldrain op de belendende sloten aangesloten. Dit betrof de behandeling Onderwaterdrains op de sloot. De drains aan de noordzijde van de percelen waren via een verzameldrain op de waterputten aangesloten. Dit betrof de behandeling Onderwaterdrains met pompbemaling. In Bijlage 2 staat een situatieschets van de behandelingen op de vier proefpercelen.

\section{Aanleg waterreservoirs}

Om in het object Onderwaterdrains met pompbemaling het peil onafhankelijk van het slootpeil te kunnen regelen, zijn de onderwaterdrains via een verzameldrain aangesloten op een afgesloten waterreservoir. De onderkant van de reservoirs ligt ongeveer een meter onder het maaiveld en de bovenkant steekt ongeveer 1,2 $\mathrm{m}$ boven het maaiveld uit. Per slootpeilregime zijn twee waterreservoirs geplaatst die via de collectordrain met elkaar verbonden waren (zie Bijlage 2). Dit is gedaan om na het onderzoek eventueel per perceel een ander peilregime te kunnen hanteren. Per slootpeil regime was één van beide waterreservoir voorzien van een pomp om water in te laten en een pomp om water uit te laten (waterreservoir op perceel 14 en 15). De pompen waren voorzien van een capaciteitsmeter om het aantal kuub in- en uitgaand water te kunnen registreren. Het waterpeil werd gemeten met een automatische hoogtemeter die op afstand uit te lezen is (zie paragraaf 4.5). Figuur 6 toont een de waterreservoirs met pomp en automatische hoogtemeter. 


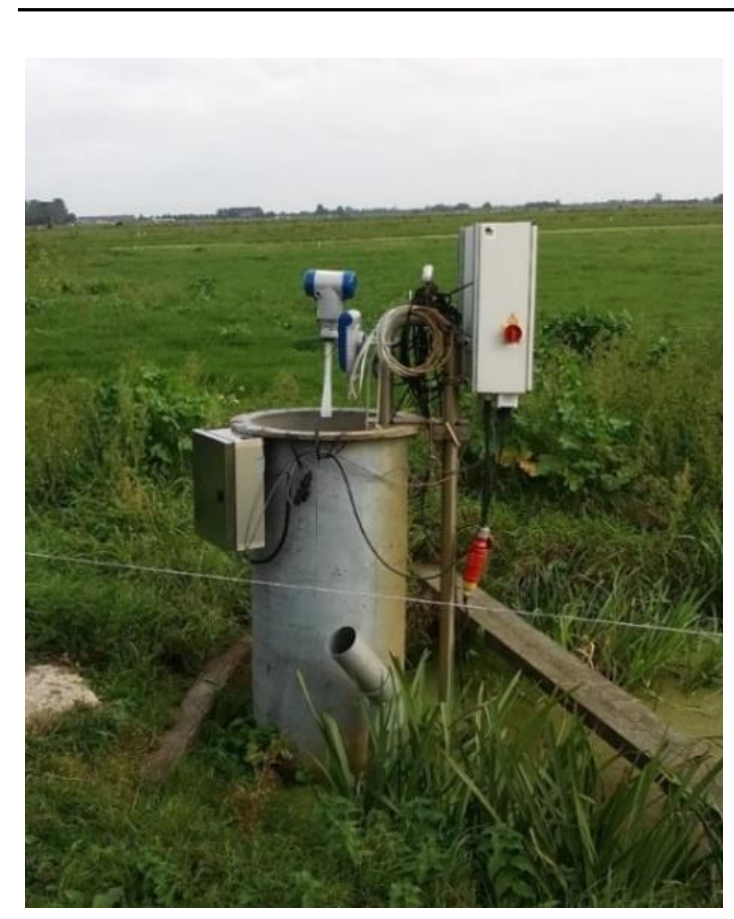

Figuur 6. Conceptuele opstelling van een waterreservoir met pomp en automatische hoogtemeting van het waterpeil in het reservoir voor toepassing van pompgestuurde onderwaterdrains. De onderwaterdrains zijn via een verzameldrain op het reservoir aangesloten.

\subsection{Peilbeheer}

Het streefpeil voor de grondwaterstand was ongeveer $40 \mathrm{~cm}$ beneden maaiveld, zoals dit is vastgesteld in een eerder onderzoek naar de toepassing van dynamisch peilbeheer (Hoving et al., 2013). Dit betekende dat voor hogere grondwaterstanden dan het streefpeil, het peil in het reservoir relatief laag moest zijn en dat omgekeerd, voor grondwaterstanden lager dan het streefpeil, het peil relatief hoog moest zijn. Doordat de waterreservoirs boven het maaiveld uitsteken, kan het peil tot aan het maaiveld of zelfs hoger ingesteld worden.

De hoogte van het peil werd bepaald op basis van weersverwachting en de actuele grondwaterstand (zie paragraaf 4.5). In Tabel 4 staat de werkwijze voor het aan- en afvoeren van water. Voor de aanvoer is onderscheid gemaakt in twee standen en bij de afvoer werd het peil maximaal verlaagd tot $70 \mathrm{~cm}$ beneden maaiveld.

Tabel 4. Peilregime pompgestuurde onderwaterdrains afhankelijk van de verwachte neerslag en de actuele grondwaterstand, zoals dat in het onderzoek op KTC Zegveld gehanteerd is.

\begin{tabular}{llllll} 
Verwachte neerslag & \multicolumn{5}{l}{ Actuele grondwaterstand $(\mathrm{cm})$} \\
\cline { 2 - 6 } dag $1-3(\mathrm{~mm})$ & $<30$ & $31-35$ & $36-40$ & $41-45$ & $>45$ \\
0 & AFVOER ${ }^{1)}$ & 0 & AANVOER-1 2) & AANVOER-2 3$)$ & AANVOER-2 \\
\hline $0-10 \mathrm{~mm}$ & AFVOER & AFVOER & 0 & AANVOER-1 & AANVOER-2 \\
\hline $10-25 \mathrm{~mm}$ & AFVOER & AFVOER & AFVOER & 0 & AANVOER-1 \\
\hline$>25 \mathrm{~mm}$ & AFVOER & AFVOER & AFVOER & AFVOER & 0 \\
\hline 1) & AFVOER & draineren peil 70 cm onder maaiveld & & & \\
2) & AANVOER-1 & infiltreren peil $10 \mathrm{~cm}$ onder maaiveld & & &
\end{tabular}

Gedurende het project is de aansturing van de pompen geautomatiseerd door met een webapplicatie de pompen op afstand aan te kunnen sturen (zie paragraaf 4.5).

Voor het peilbeheer werd dagelijks in drie referentiepeilbuizen de grondwaterstand gemeten. Dit betrof telkens de eerste peilbuis (gerekend vanaf het proefbedrijf) van de drie meetraaien op het 
object Pompgestuurde onderwaterdrains. Aanvullend werden voor het peilbeheer metingen van de automatische drukopnemers (divers) gebruikt. In Bijlage 3 staat een logboek van de gemeten grondwaterstanden en de peilaanpassing voor de proefpercelen in 2017.

\subsection{Teelt en bemesting}

Voor de N1 velden werd een stikstofbemestingsniveau gehanteerd van $210 \mathrm{~kg} \mathrm{~N}$ per ha, De N0-velden kregen geen stikstof toegediend. De bemestingshoeveelheden voor $\mathrm{N}, \mathrm{P}_{2} \mathrm{O}_{5}$ en $\mathrm{K}_{2} \mathrm{O}$ in de vorm van kunstmest staan in Tabel 5.

Tabel 5. Bemestingshoeveelheden $\mathrm{N}, \mathrm{P}_{2} \mathrm{O}_{5}$ en $\mathrm{K}_{2} \mathrm{O}$ per proefperceel in de vorm van kunstmest.

\begin{tabular}{lcccccc} 
Snede & 1 & 2 & 3 & 4 & 5 & totaal \\
$\mathrm{N}$ (kg per ha) & 80 & 50 & 40 & 40 & - & 210 \\
\hline $\mathrm{P}_{2} \mathrm{O}_{5}$ (kg per ha) & 45 & 30 & 30 & 30 & - & 135 \\
\hline $\mathrm{K}_{2} \mathrm{O}$ (kg per ha) & 100 & 100 & 100 & 100 & - & 400 \\
\hline
\end{tabular}

\subsection{Waarnemingen}

\section{Grondwaterstanden}

Het meten van grondwaterstanden gebeurde volgens twee methoden namelijk (1) continumetingen met automatische drukopnemers (divers) in een select aantal peilbuizen om de variatie in de tijd vast te kunnen stellen en (2) handmatige wekelijkse metingen in een groot aantal peilbuizen verspreid over de behandelingen om de ruimtelijke variatie in de metingen mee te kunnen nemen.

Op de objecten Geen onderwaterdrains en Onderwaterdrains op de sloot waren 9 peilbuizen geplaatst. Op het object Pompgestuurde onderwaterdrains waren 18 peilbuizen geplaatst, omdat de oppervlakte van dit object groter was. Alle buizen zijn midden tussen de drainagebuizen geplaatst, dus halverwege de drainageafstand. De peilbuizen werden beschermd met een tegel die in de graszode was aangebracht. De tegels waren voorzien van een gat om met een meetlint de grondwaterstand in de peilbuis te kunnen meten.

De proefobjecten waren voorzien van automatische drukopnemers om de grondwaterstand in een aaneengesloten tijdreeks te kunnen monitoren. Per object was één drukopnemer geplaatst en alleen op bij Pompgestuurde onderwaterdrains waren de drukopnemers uitgerust met een datalogger om de grondwaterstand real time te kunnen monitoren. De metingen met de automatische drukopnemers waren input voor de besturing van de pompgestuurde onderwaterdrains en zijn gebruikt als aanvulling op de wekelijkse handmatige metingen.

\section{Slootpeilen}

Evenals de grondwaterstanden werden de slootpeilen gemonitord door middel van frequente metingen. Tegelijkertijd met de grondwaterstanden werden de slootpeilen wekelijks handmatig gemeten. Voor Pompgestuurde onderwaterdrains werden de slootpeilen aanvullend met automatische drukopnemers gemeten om te zien in hoeverre de aan- en afvoer van water met putbemaling het slootpeil beïnvloedt.

\section{Grasopbrengst en ruw-eiwit}

Op de proefpercelen waren proefvakken aangelegd om de grasopbrengst te kunnen bepalen door middel van maaien. Binnen de proefvakken waren door middel van loting de twee N-niveaus (NO en $\mathrm{N} 1$ ) in tweevoud op veldjes van 1,5 x $10 \mathrm{~m}$ geplaatst. De grassneden werden met een speciaal hiervoor ontwikkelde proefveldmaaier (Haldrup $\left.{ }^{\circledR}\right)$ gemaaid. Het verse gras werd daarbij automatisch gewogen. Van het verse gras werden door middel van meerdere steken met een verzamelboor een grasmonster genomen voor het bepalen van het drogestofgehalte. De grasmonsters werden gewogen, gedroogd en teruggewogen. Het drogen gebeurde in een droogstoof bij $75^{\circ} \mathrm{C}$ gedurende 24 uur. Per opbrengststrook werden meerdere monsters genomen van het vers gemaaide gras. Deze werden per veldje samengevoegd tot een verzamelmonster en geanalyseerd op $\mathrm{N}$-totaal voor de vertaling in ruw- 
eiwit ( $\left.N_{\text {totaal }} \times 6,25\right)$. De grasmonsters werden geanalyseerd door middel van NIRS (gedroogde en gemalen monsters).

\section{Botanische samenstelling}

Van de proefpercelen is aan het eind van proefperiode de botanische samenstelling gekarteerd. De resultaten zijn vooral van belang voor het beoordelen van de gerealiseerde grasopbrengsten en stikstofgehaltes van het gras. Door maaien kan namelijk de botanische samenstelling vrij snel veranderen (vooral een toename van het aandeel kweek), wat invloed kan hebben op de resultaten. De proefperiode was te kort om een verandering van de botanische samenstelling door de proefbehandelingen te verwachten.

\section{Hoogtemetingen}

In het najaar van 2017 is per peilbuis de hoogte van het maaiveld vastgesteld ten opzichte van NAP om de metingen van de peilbuizen onderling te kunnen vergelijken. Met een waterpasinstrument werd de hoogte van de bovenkant van de tegels (bescherming peilbuizen) gemeten ten opzichte van een vast geregistreerd punt.

\subsection{Neerslag}

Het effect van de onderwaterdrains is bepaald door het verschil in grondwaterstanden te analyseren tussen de drie drainbehandelingen. Neerslag en verdamping hebben een grote invloed op de aan- en afvoer van water. Bij een neerslagoverschot zijn de peilen relatief hoog en bij een verdampingsoverschot relatief laag. Verder zijn greppels, slootafstand, slootpeil, de mate van infiltratie en drainage, en de hoeveelheid kwel en wegzijging belangrijke factoren.

De neerslagsommen per maand en per jaar, afkomstig van het KNMI- neerslagstation Zegveld (470), staan in Tabel 6. De neerslagsommen geven een zeer globaal beeld van het neerslag patroon gedurende het jaar. In 2016 viel vooral de maand juni veel neerslag en in 2017 was dit het geval in de maanden juli en september.

Tabel 6. Neerslagsom in $\mathrm{mm}$ per maand 2016 en 2017.

\begin{tabular}{lrr} 
& 2016 & 2017 \\
Januari & 148 & 75 \\
\hline Februari & 102 & 83 \\
\hline Maart & 68 & 58 \\
\hline April & 98 & 33 \\
\hline Mei & 77 & 43 \\
\hline Juni & 178 & 44 \\
\hline Juli & 75 & 161 \\
\hline Augustus & 56 & 75 \\
\hline September & 46 & 128 \\
\hline Oktober & 67 & 84 \\
\hline November & 105 & 90 \\
\hline December & 19 & 152 \\
\hline Totaal & 1.038 & 1.025 \\
\hline
\end{tabular}

Het neerslagpatroon komt tot uiting in de gemeten grondwaterstanden. Om het effect van neerslag op de grondwaterstand goed te analyseren moeten de neerslaggegevens op dagbasis beschouwd worden en moeten ook de verdampingsgevens in de analyse betrokken worden. Het analyseren van het grondwaterstandverloop in relatie tot het weerbeeld en de bodemkarakteristiek kan worden uitgevoerd met een hydrologisch model zoals SWAP (Kroes en Van Dam, 2003). 
Aangezien deze rapportage gericht is op het aantonen van verschillen tussen objecten en niet op het verklaren van het grondwaterstandverloop per object, zijn de neerslaggegevens verder niet in detail gebruikt.

\subsection{Analyse}

\section{Grondwaterstanden}

Het verloop van de grondwaterstanden van de onderzoeksobjecten is vergeleken en de maximale verschillen in het winter- en zomerhalfjaar zijn aangegeven. De grondwaterstanden zijn niet statistische geanalyseerd in tegenstelling tot eerdere onderzoeken (Hoving et al., 2008, 2013 en 2015). In deze onderzoeken werd een cyclisch verloop van de grondwaterstand binnen een jaar verondersteld, aangezien gemiddeld de grondwaterstanden in de winter relatief hoog en in de zomer relatief laag zijn. De basis voor de analyse was een fitting van de wekelijks gemeten grondwaterstanden volgens een sinusoïde curve. De modelparameters werden vervolgens getoetst. Dit is weliswaar een sterke versimpeling van de werkelijkheid, maar maakt het mogelijk om in grote lijn het verschil in grondwaterstandverloop tot uitdrukking te brengen en te toetsen.

Met pompgestuurde drainage worden de grondwaterstanden actief gestuurd en volgen in principe niet meer het cyclische verloop, waardoor een analyse volgens een sinusoïde model geen passende benadering is. Proceskennis speelt bij de beoordeling van de resultaten een belangrijke rol en die laat zich in dit geval moeilijk vangen in een statistische analyse.

\section{Grasopbrengsten}

Met behulp van een ANOVA-model zijn de drogestofopbrengst en de stikstofopbrengst van 2016 en 2017 geanalyseerd per kalenderjaar en over de kalenderjaren heen. Hiervoor is het programma Genstat gebruikt (Genstat 6. Committee, 2002). Het model bevatte hoofdeffecten en interacties van de proeffactoren slootpeil, drainage en stikstofbemesting. Bij de analyse over de jaren is het model uitgebreid met het hoofdeffect kalenderjaar en interacties tussen de proeffactoren en kalenderjaar. In de modellen waren de interacties beperkt tot twee en drie factorinteracties. In het ANOVA model zijn additionele randomeffecten opgenomen voor verschillen tussen percelen binnen een slootpeil en voor variatie tussen paren van veldjes met dezelfde stikstofbehandeling binnen drainage plots. Dit is gedaan om de afhankelijkheid tussen metingen bij een zelfde slootpeil of op hetzelfde perceel te beschrijven. Het statistische model voor de waargenomen stikstofopbrengst was:

$Y=\mu+$ hoofdeffecten +2 factorinteracties +3 factorinteracties + eperceel + eveldje + rest error

met randomeffecten voor achtereenvolgens perceel binnen een zelfde slootpeil en een set van twee veldjes binnen drainage plot en residu. Voor de slootpeilen misten echte herhalingen, waardoor het effect van slootpeil niet getoetst kon worden. 


\section{Resultaten}

\subsection{Grondwaterstanden}

De grondwaterstanden zijn gemeten van 1 april 2016 tot en met 20 december 2017. Tot 22 juni 2016 was het waterpeil in de waterreservoirs gelijk aan het slootpeil, omdat de apparatuur voor het reguleren van het peil in de reservoirs nog niet operationeel was. Vanaf 22 juni 2016 is het peil in de reservoirs afhankelijk gesteld van de actuele grondwaterstand en de weersverwachting, zoals dat in paragraaf 3.3 is gespecificeerd. In Figuur 7 tot en met 10 staan de resultaten voor de proefpercelen 13 tot en met 16. De grondwaterstanden zijn per meetmoment per drainbehandeling gemiddeld en weergegeven ten opzichte van de gemiddelde maaiveldhoogte van het betreffende perceel.

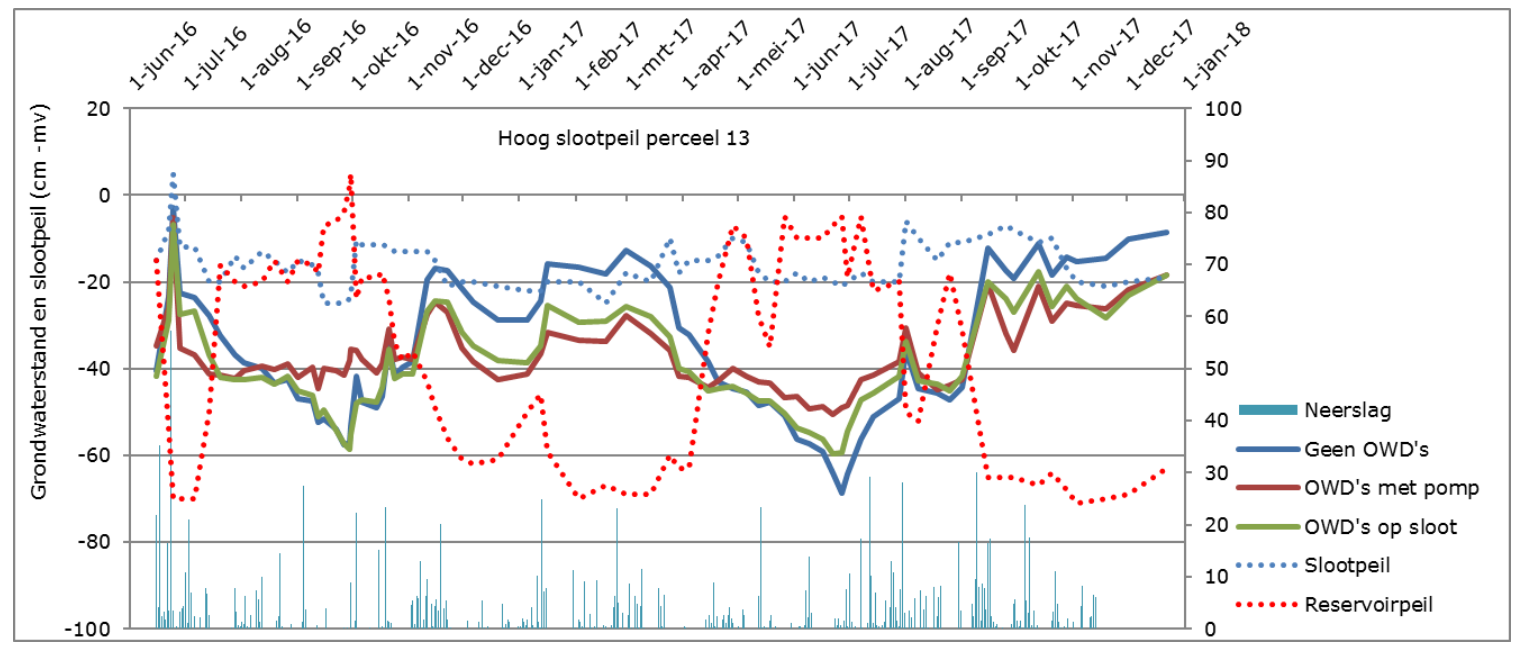

Figuur 7. Het verloop van de grondwaterstand per drainbehandeling (geen onderwaterdrains, traditionele onderwaterdrains op de sloot en pompgestuurde onderwaterdrains), slootpeil en reservoirpeil voor perceel 13 bij een vast hoog slootpeil met een drooglegging van 20 $\mathrm{cm}$ beneden maaiveld.

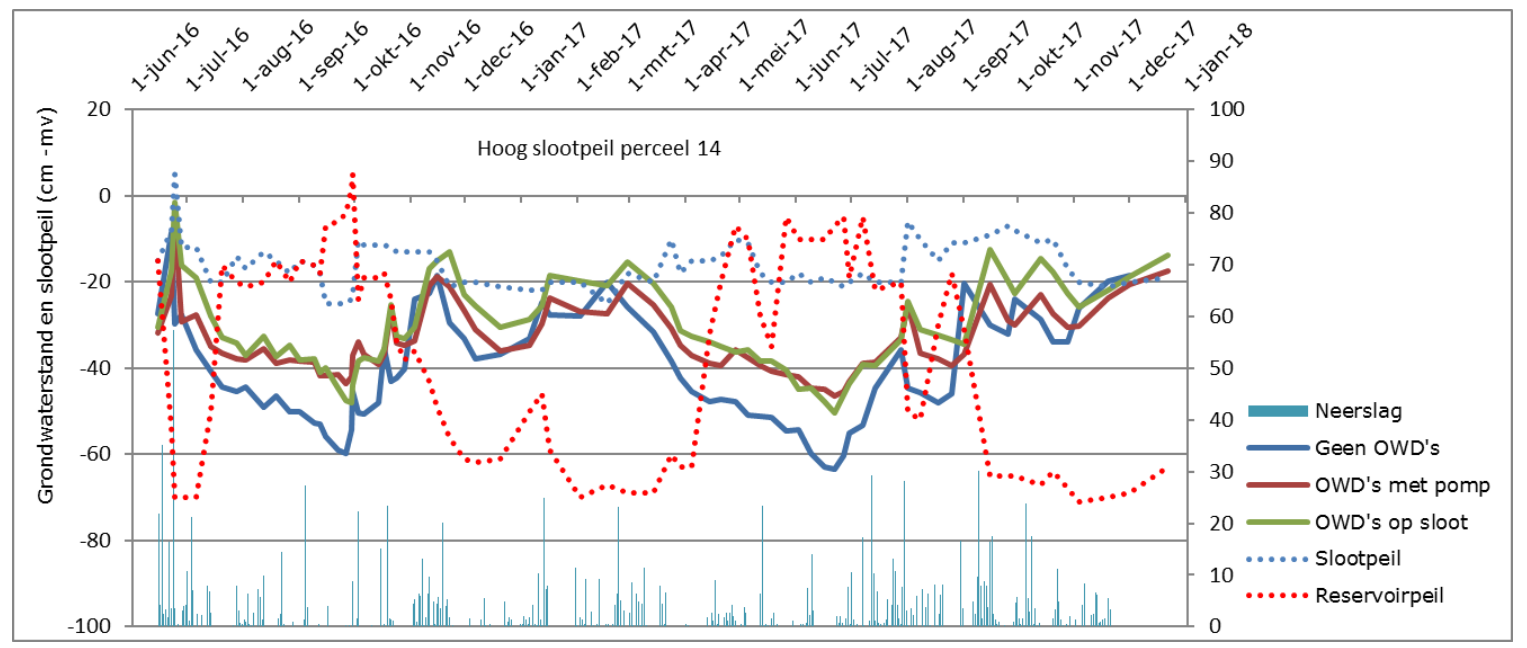

Figuur 8. Het verloop van de grondwaterstand per drainbehandeling (geen onderwaterdrains, traditionele onderwaterdrains op de sloot en pompgestuurde onderwaterdrains), slootpeil en reservoirpeil voor perceel 14 bij een vast hoog slootpeil met een drooglegging van 20 $\mathrm{cm}$ beneden maaiveld. 


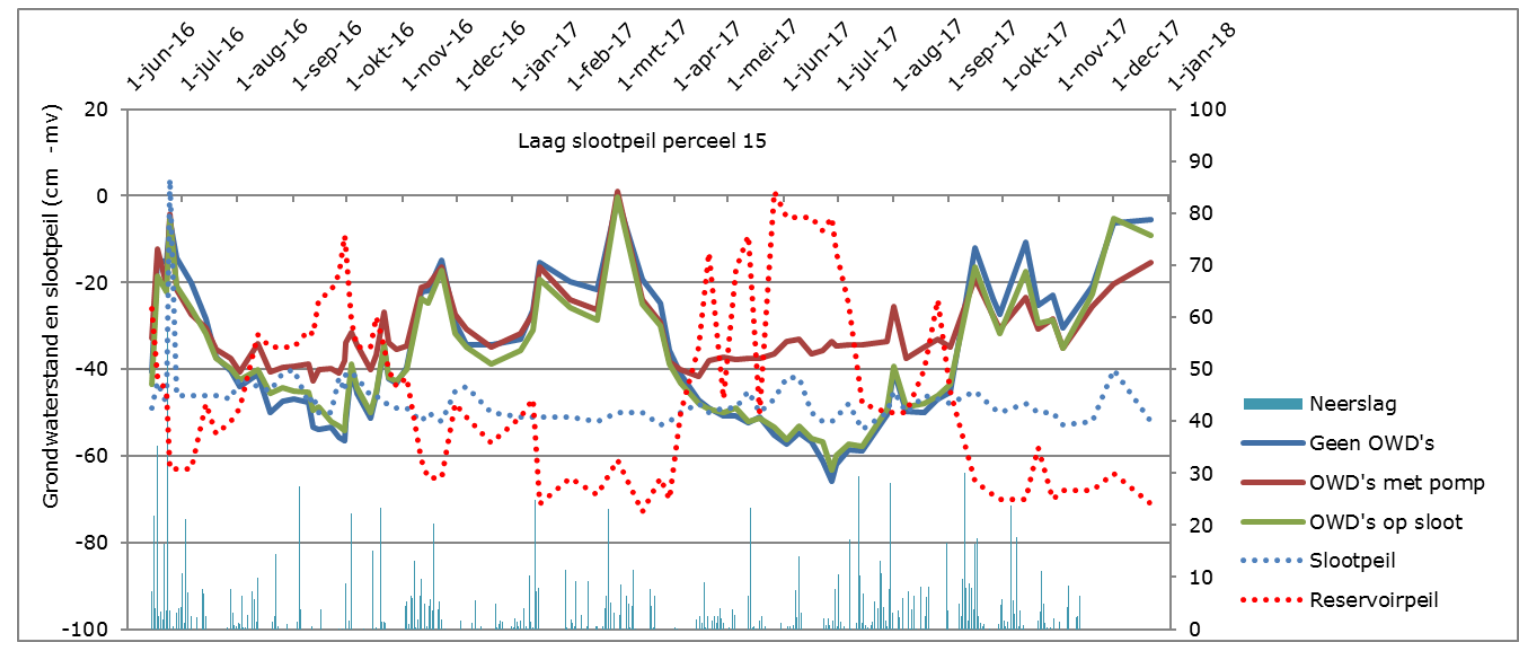

Figuur 9. Het verloop van de grondwaterstand per drainbehandeling (geen onderwaterdrains, traditionele onderwaterdrains op de sloot en pompgestuurde onderwaterdrains), slootpeil en reservoirpeil voor perceel 15 bij een vast 'laag' slootpeil met een drooglegging van 55 $\mathrm{cm}$ beneden maaiveld.

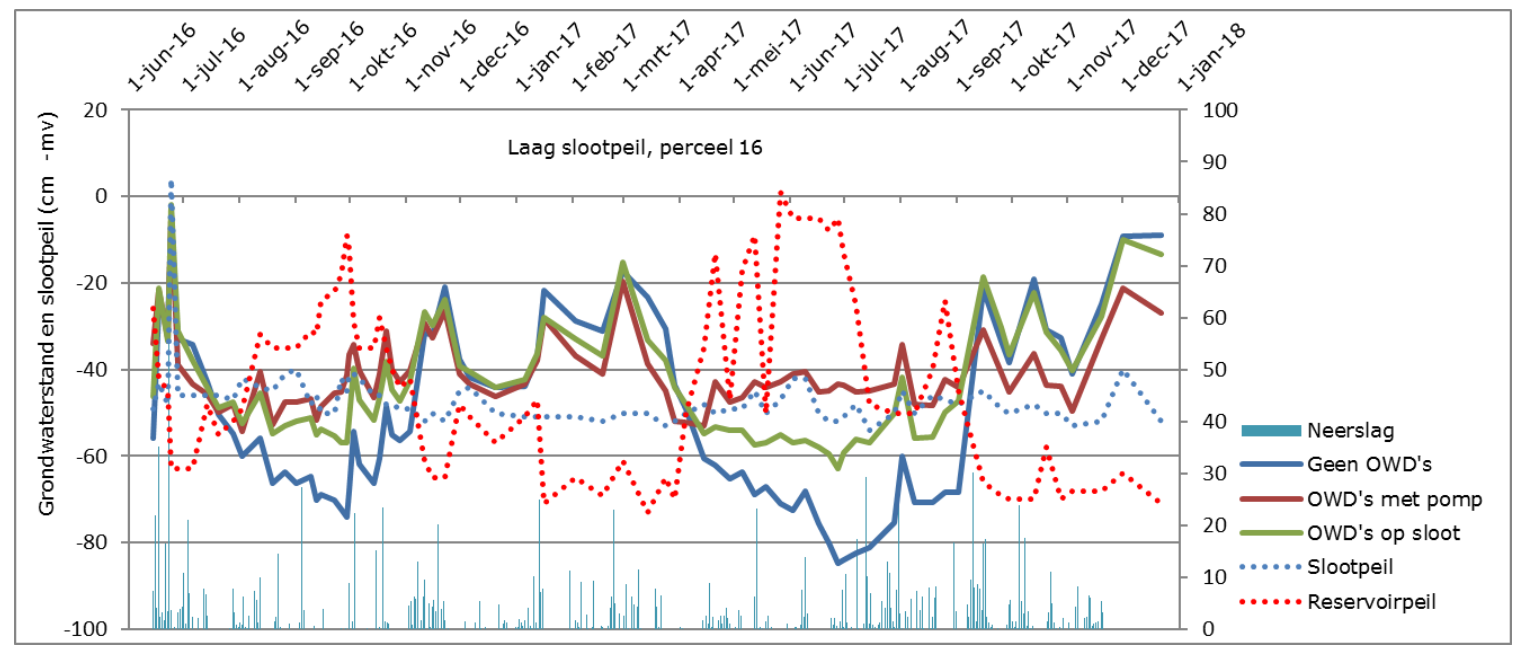

Figuur 10. Het verloop van de grondwaterstand per drainbehandeling (geen onderwaterdrains, traditionele onderwaterdrains op de sloot en pompgestuurde onderwaterdrains), slootpeil en reservoirpeil voor perceel 16 bij een vast 'laag' slootpeil met een drooglegging van 55 $\mathrm{cm}$ beneden maaiveld.

De figuren laten zien dat bij Onderwaterdrains op de sloot de grondwaterstand in het zomerhalfjaar tot ongeveer 60 à $65 \mathrm{~cm}$ onder maaiveld daalde, gelijk of hoger dan Geen onderwaterdrains. Daar waar de grondwaterstanden bij Onderwaterdrains op de sloot gelijk waren aan die van Geen Onderwaterdrains was de grondwaterstand relatief hoog of was het verschil tussen het slootpeil en de grondwaterstand relatief klein. Zo was op perceel 15 in de drogere perioden het verschil tussen het slootpeil en de grondwaterstand maximaal $10 \mathrm{~cm}$, waardoor het potentiaalverschil bij een k-waarde van 0,12 m per dag waarschijnlijk te gering was om extra water te infiltreren. Met Pompgestuurde onderwaterdrains was het verschil aanmerkelijk groter dan bij Onderwaterdrains op de sloot. In het zomerhalfjaar kon de grondwaterstand redelijk op het streefpeil van $40 \mathrm{~cm}$ beneden maaiveld worden gehouden, bij zowel het hoge als het lagere slootpeil. Dit is een zeer gunstige indicatie voor het verminderen van veenafbraak (zie Hoofdstuk Discussie).

In het winterhalfjaar van 2016-2017 hadden Onderwaterdrains op de sloot vooral op perceel 13 een verlagend effect op de grondwaterstand. Dit betekent dat tijdens een situatie van een neerslagoverschot extra water werd afgevoerd vanuit de percelen naar de sloot. Op perceel 14 werd daarentegen de waterafvoer geremd Onderwaterdrains op de sloot. Bij het gehanteerde hoge slootpeil is dit ook de verwachting vanwege het geringe potentiaalverschil. Perceel 13 heeft een greppel in het 
midden van het perceel, die op een sloot met een lager peil afvoert, en dit kan voor extra waterafvoer hebben gezorgd ten gunste voor Onderwaterdrains op de sloot. Niet duidelijk is waarom bij Onderwaterdrains op de sloot wel extra waterafvoer zou optreden en bij Geen onderwaterdrains niet. Perceel 14, 15 en 16 hebben geen greppel.

Pompgestuurde onderwaterdrains vergrootten de waterafvoer in natte perioden. Vooral in het relatief natte najaar van 2017 hadden Pompgestuurde onderwaterdrains een additioneel drainerend effect ten opzicht van Onderwaterdrains op de sloot. Tijdens neerslagpieken in het zomerhalfjaar steeg het grondwaterpeil op alle drainobjecten gemakkelijk tot in het maaiveld, echter het teveel aan water werd bij Pompgestuurde onderwaterdrains sneller afgevoerd, zoals na de neerslagpieken op 23 juni 2016 (57 mm) en 30 juli 2017 ( $28 \mathrm{~mm}$ ). Overigens steeg tijdens de neerslagpiek van 23 juni 2016 het slootpeil van zowel het lage als het hoge peil tot boven het gemiddelde maaiveldniveau van de betreffende percelen ( $5 \mathrm{~cm}$ boven maaiveld). Dit betekende dat de percelen gedurende korte tijd voor een groot deel onder water hebben gestaan. Het boezempeil van de polder was op dat moment zodanig hoog dat de waterafvoer voor geheel KTC Zegveld stagneerde.

Door de snellere afvoer bij Pompgestuurde onderwaterdrains was de draagkracht sneller weer toereikend voor betreding en berijding. De verandering in draagkracht is niet gemeten, maar het verschil tussen de drainobjecten werd al lopend over het perceel wel fysiek waargenomen.

Om het infiltrerende en drainerende effect van de beide drainobjecten ten opzichte van de situatie zonder onderwaterdrains te kwantificeren, staat in Tabel 7 het maximale verschil in grondwaterstand tussen Geen onderwaterdrains en Onderwaterdrains op de sloot en Pompgestuurde onderwaterdrains per perceel voor het zomer- en winterhalfjaar in 2016 en 2017.

Tabel 7. Maximaal verschil in grondwaterstand $(\mathrm{cm})$ tussen Geen onderwaterdrains (OWD's) en respectievelijk Onderwaterdrains op de sloot en Pompgestuurde onderwaterdrains per proefperceel voor het zomer- en winterhalfjaar in 2016 en 2017. Positieve verschillen betekenen hogere grondwaterstanden en negatieve verschillen duiden op lagere grondwaterstanden ten opzichte van grondwaterstanden bij Geen onderwaterdrains

\begin{tabular}{|c|c|c|c|c|c|}
\hline & & \multicolumn{2}{|c|}{2016} & \multicolumn{2}{|c|}{2017} \\
\hline \multirow{2}{*}{ Zomer } & PR14 & 14 & 18 & 17 & 18 \\
\hline & PR16 & 11 & 22 & 26 & 41 \\
\hline \multirow[t]{3}{*}{ Winter } & PR13 & -10 & -14 & -14 & -17 \\
\hline & PR14 & 13 & 14 & 12 & 9 \\
\hline & PR15 & -4 & -2 & -7 & -14 \\
\hline
\end{tabular}

De drainbehandelingen hadden niet alleen effect op de mate van infiltratie en drainage, maar ook op de variatie in grondwaterstand binnen het betreffende perceelsvak (object). De variatie in grondwaterstanden tussen de verschillende peilbuizen per drainbehandeling per perceel staat in Tabel 8. 
Tabel 8. Variatie grondwaterstanden ( $\mathrm{cm}$ ) per perceel voor Geen onderwaterdrains (OWD's), Onderwaterdrains op de sloot en Pompgestuurde onderwaterdrains.

\begin{tabular}{lccc} 
Percelen & Geen OWD's & OWD's sloot & OWD's pompgestuurd \\
13 & 15.1 & 11.0 & 8.5 \\
\hline 14 & 11.9 & 10.1 & 8.4 \\
\hline 15 & 14.9 & 12.9 & 8.5 \\
\hline 16 & 18.9 & 13.3 & 9.2 \\
\hline
\end{tabular}

De variatie in grondwaterstanden was het grootst voor Geen onderwaterdrains. Onderwaterdrains op de sloot hadden een kleinere variatie en bij Pompgestuurde onderwaterdrains was de variatie nog kleiner. In Bijlage 4 is de variatie in grondwaterstanden per perceel grafisch weergegeven.

Naast de wekelijkse handmatige metingen van de grondwaterstand is gebruik gemaakt van automatische drukopnemers die op de objecten van de pompgestuurde onderwaterdrains geplaatst waren. De resultaten van deze metingen en die van de handmatige metingen staan in de Figuur 1 tot en met 4 van Bijlage 5 . Voor de handmatige metingen is onderscheid gemaakt in de metingen gemiddeld over het gehele perceel, nabij de peilbuis van de automatische drukopnemer en de drie refentiepeilbuizen die gebruikt werden voor het peilbeheer (perceel 14 en 15).

De metingen van de automatische drukopnemer en de handmatige metingen nabij de automatisch drukopnemer komen redelijk goed overeen. Dit betekent dat de betrouwbaarheid van de meting zelf goed is, maar de metingen werden nog wel eens verstoord door een storing in de stroomvoorziening (defecte baterijen) of een verbroken connectie tussen de drukopnemer en de datalogger. De betreffende percelen werden begraasd met melkkoeien waardoor, ondanks de bescherming toch verstoring optrad. Op perceel 15 heeft uiteindelijk de drukopnemer slecht gedurende een korte tijd gewerkt. Een voordeel van de automatische drukopnemers is dat de meetfrequentie veel hoger ligt, zodat de variatie in grondwaterstanden beter zichtbaar wordt. Met de vele peilbuizen die handmatig gemeten werden, werd de ruimtelijke verdeling echter goed in beeld gebracht. De metingen van de automatisch drukopnemer weken hier soms van af, zoals op perceel 14 in de zomerperiode van 2017. Op perceel 16 laat de drukopnemer een relatief grote variatie zien in grondwaterstanden. Op perceel 15 is het verschil tussen de drie referentiepeilbuizen en het perceelgemiddelde vrij groot (tot $10 \mathrm{~cm}$ ) in de zomerperiode van 2017. De referentiemetingen waren daarbij lager, waardoor de aansturing van de pompgestuurde onderwaterdrains in deze periode tot relatief hoge grondwaterstanden leidden, hoger dan het streefpeil.

\subsection{Watergebruik}

De hoeveelheid water die per ontwateringssituatie het waterreservoir in- en uitgepompt werd van en naar het oppervlaktewater werd automatisch gemeten en geregistreerd. In Figuur 11 en 12 staat voor respectievelijk een hoog en een lager slootpeil de hoeveelheden water die dagelijks de waterreservoirs in of uitgepompt werden in de proefperiode van 22 juni 2016 tot en met 22 december 2017. Het gehanteerde peil in de waterreservoirs is eveneens weergegeven. Overigens is de datareeks op een aantal momenten onderbroken door storing in de apparatuur. 


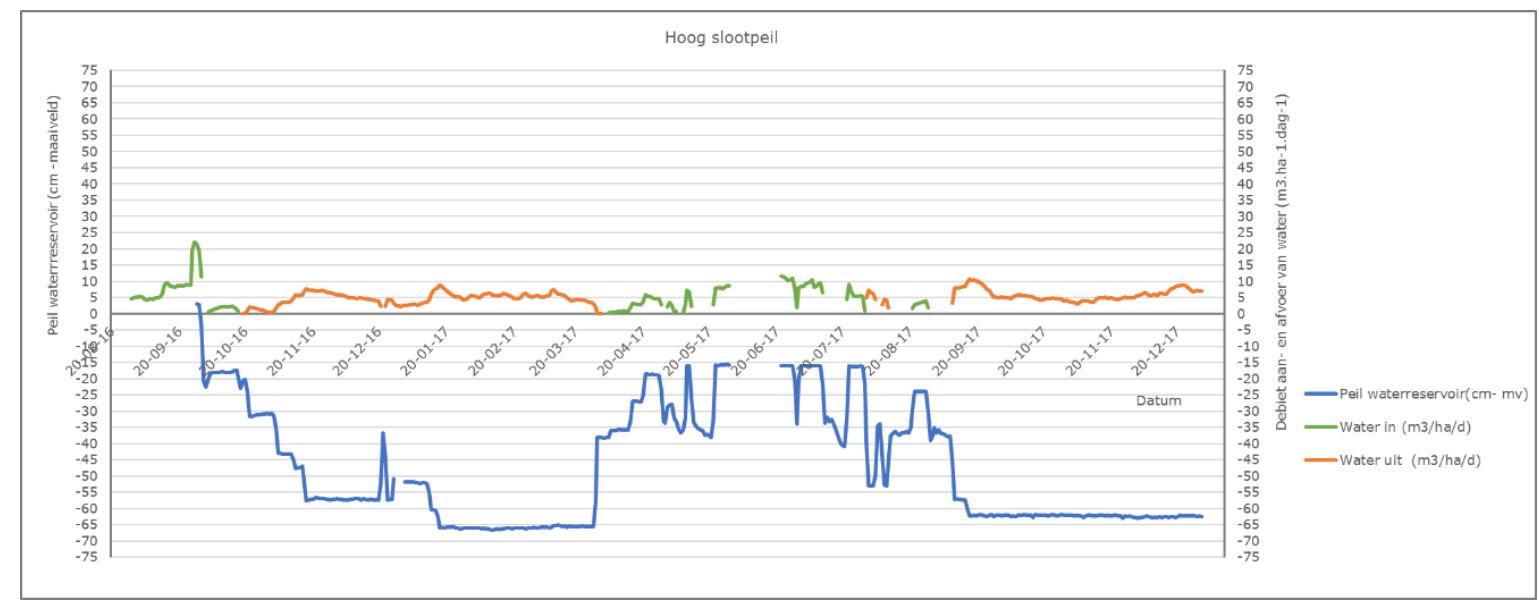

Figuur 11. Dagelijkse hoeveelheid water ( $m^{3}$ per ha per dag) die de waterreservoirs in- en uitgepompt werd bij het hoge slootpeil met een droogleging van $20 \mathrm{~cm}$ beneden maaiveld in de periode van 22 juni 2016 tot en met 22 december 2017.

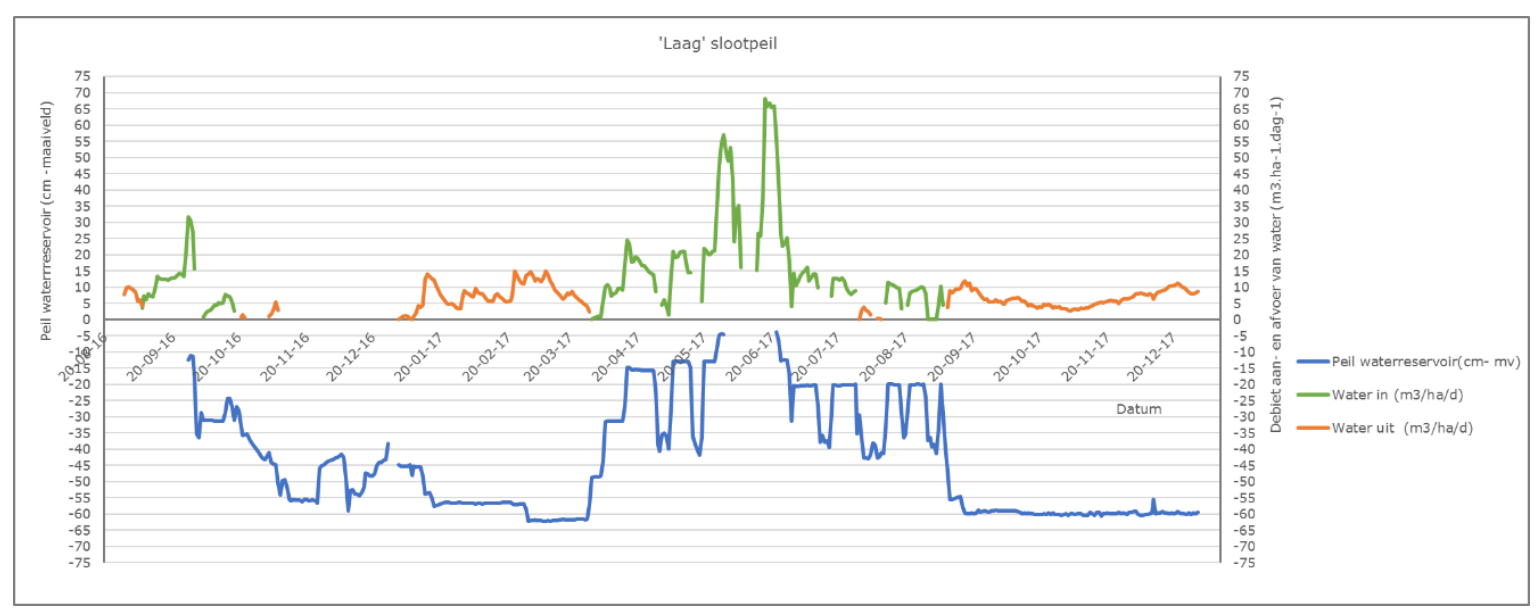

Figuur 12. Dagelijkse hoeveelheid water ( $m^{3}$ per ha per dag) die de waterreservoirs in- en uitgepompt werd bij het lage slootpeil met een drooglegging van $55 \mathrm{~cm}$ beneden maaiveld in de periode van 22 juni 2016 tot 22 december 2017.

Vooral de hoeveelheden water die de waterreservoirs ingepompt werden tijdens een neerslagtekort verschilden aanzienlijk. Bij het hoge slootpeil was dit gemiddeld 2 à 3 keer kleiner dan bij het lagere slootpeil, enerzijds door extra infiltratie vanuit de sloot bij een hoog peil en anderzijds extra drainage vanuit de bodem naar de sloot bij een laag slootpeil. In feite werd water rondgepompt vanuit de sloot in het waterreservoir, via de onderwaterdrains en de bodem terug naar de sloot. De maximale en de gemiddelde hoeveelheid water die de waterreservoirs in en uitgepompt werd bij het hoge en lage slootpeil in de periode van 22 juni 2016 tot 22 december 2017 staat in Tabel 9.

Tabel 9. Maximale en gemiddelde hoeveelheid water ( $m^{3}$ per ha per dag) die de waterreservoirs in en uitgepompt werden bij het hoge en lage slootpeil in de periode van 22 juni 2016 tot en met 22 december 2017.

(20 $\mathrm{cm}$ beneden maaiveld) $\quad$ Laag slootpeil
(55 cm beneden maaiveld)

\begin{tabular}{lcccc} 
Maximaal & 22 & 11 & 68 & 15 \\
\hline Gemiddelde & 6 & 5 & 16 & 7
\end{tabular}




\subsection{Grasopbrengsten}

\section{Drogestofopbrengst}

De grasopbrengsten per perceel per veldje staan in Bijlage 6. Bij het bepalen van het drogestofgehalte bleek voor een aantal veldjes in meerdere sneden het gras verontreinigd met zand, waardoor het drogestofgehalte sterk afweek. Daarbij is in 2016 de groei van de laatste snede op perceel 13 en 14 verstoord door weidend vee. In Bijlage 6 is aangegeven welke veldjes een afwijkend drogestofgehalte hadden en van welke veldjes de groei verstoord was. Deze laatste veldjes zijn uitgesloten voor de analyse. Voor de veldjes met zand verontreinigde grasmonsters zijn de drogestofgehaltes van de duplo veldjes gebruikt om tot een drogestofopbrengst te komen, zodat van de betreffende opbrengstbepalingen gebruik gemaakt kon worden.

De hoofdeffecten waren beperkt tot Jaar en Stikstofbemesting. Slootpeil en Drainage hadden als hoofdbehandeling geen significant effect op de opbrengst. Jaar had een interactie-effect met Slootpeil en met Stikstofbemesting. De interactie van Jaar $x$ Slootpeil wordt echter voor een belangrijk deel bepaald door de missende waarnemingen in 2016 bij het hoge slootpeil.

De gemiddelde drogestofopbrengsten voor Jaar $x$ Stikstofbemesting staan in Tabel 10. Daarbij staan tevens de overschrijdingskansen ( $p$-waarden), als kengetal voor de mate van significantie, en de kleinste significante verschillen (LSD-waarden) vermeld. Met letters zijn de significante verschillen aangeduid. De verschillen voor tussen de stikstofbemestingsniveaus zijn sterk significant en de verschillen tussen de slootpeilen zijn zeer sterk significant. De analyseresultaten voor Jaar $x$ Slootpeil zijn niet in een tabel weergeven, vanwege de aangegeven missende waarnemingen, waardoor de resultaten niet goed vergeleken kunnen worden.

Tabel 10. Gemiddelde drogestofopbrengst per ha per jaar voor de behandeling Stikstofbemesting. Met letters zijn de significante verschillen aangeduid. De overschrijdingskans ( $p$-waarde), als kengetal voor de mate van significantie, bedroeg 0,004 (sterk significant) en het kleinste significante verschil (LSD-waarde) bedroeg $499 \mathrm{~kg}$ drogestof per ha.

$\begin{array}{rrrrr}\text { Jaar } & \text { No } & & \\ & & & \\ & & & \\ 2016 & 9299 & \text { a } & 13192 & \text { c } \\ 2017 & 11817 & \text { b } & 14647 & \text { d }\end{array}$

Het is bekend dat grasopbrengst sterk op stikstofbemesting reageert. De resultaten in Tabel 9 bevestigen dit. Op veengrond is de stikstoflevering uit de bodem door mineralisatie van organische stof relatief hoog met een grote variatie (160 tot $300 \mathrm{~kg}$ per ha per jaar, zie Tabel 1), waardoor de onbemeste objecten in verhouding tot de bemeste objecten een relatief hoge opbrengst hadden (zie ook de volgende paragraaf). Het interactie-effect werd veroorzaakt door het grotere verschil in opbrengsten in 2016 dan in 2017.

Voor een algemeen beeld staan de resultaten voor drogestof samengevat in Figuur 13, afhankelijk van jaar, stikstofbemesting en slootpeil. Het verschil tussen hoog en laag slootpeil in 2016 was overschat door het wegvallen van de vijfde snede voor het hoge slootpeil. Hierdoor kunnen de resultaten van de slootpeilen in 2016 niet onderling vergeleken worden. Binnen slootpeil zijn de stikstofeffecten zichtbaar. In 2016 was het verschil groter dan in 2017. 


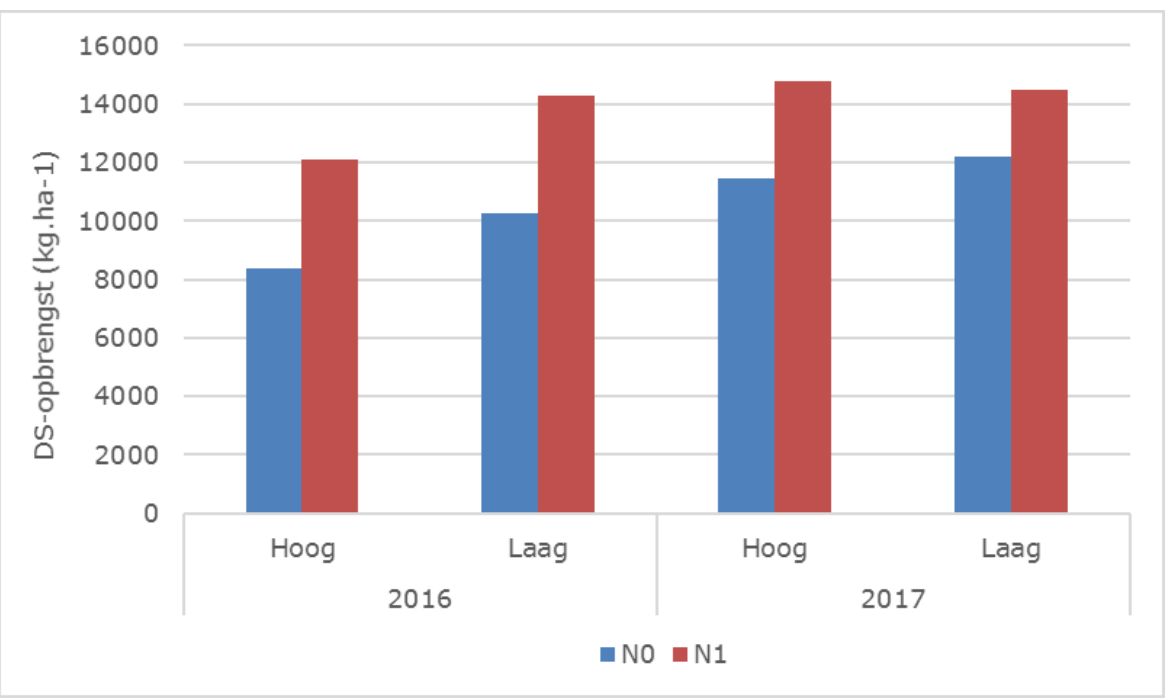

Figuur 13. Drogestofopbrengsten 2016 en 2017 voor de behandelingen Slootpeil en Stikstofbemesting. Door het wegvallen van de vijfde snede voor het hoge slootpeil in 2016 kunnen de resultaten van beide slootpeilen in dit jaar niet onderling vergeleken worden.

\section{Stikstofopbrengst}

De stikstofopbrengsten per perceel per veldje staan in Bijlage 7. Evenals voor de drogestofopbrengsten is aangegeven welke veldjes een afwijkend drogestofgehalte hadden en van welke veldjes de groei verstoord was. Voor de analyse zijn dezelfde aanpassingen gedaan als voor de drogestofopbrengsten (zie vorige paragraaf).

De hoofdeffecten waren beperkt tot Jaar en Stikstofbemesting. Slootpeil en Drainage waren als hoofdbehandelingen niet significant. Jaar gaf een tweeweginteractie-effect met Stikstofbemesting en Drainage en een drieweginteractie-effect met Stikstofbemesting en Slootpeil. De gemiddelde stikstofopbrengsten voor Jaar $x$ Stikstofbemesting staan in Tabel 11. Daarbij staan de overschrijdingskansen ( $p$-waarden), als kengetal voor de mate van significantie, en de kleinste significante verschillen (LSD-waarden) vermeld. Met letters zijn de significante verschillen aangeduid.

Tabel 11. Gemiddelde stikstofopbrengst per ha per jaar voor de behandeling Stikstofbemesting. Met letters zijn de significante verschillen aangeduid. De overschrijdingskans ( $p$-waarde), als kengetal voor de mate van significantie, bedroeg 0,023 (significant) en het kleinste significante verschil (LSD-waarde) bedroeg 13,6 kg stikstof per ha.

\begin{tabular}{lllll} 
Jaar & & & N1 \\
& & & & \\
2016 & 226 & a & 380 & c \\
\hline 2017 & 329 & b & 460 & d
\end{tabular}

De resultaten voor de behandeling Stikstofbemesting laten een groot verschil in stikstofopbrengst tussen beide jaren zien. Voor N0 bedroeg dit ongeveer $100 \mathrm{~kg}$. Dit betekent dat de mineralisatie per jaar aanzienlijk verschilt.

De resultaten voor Jaar $x$ Drainage staan in Tabel 12. Daarbij staan de overschrijdingskansen ( $p$ waarden), als kengetal voor de mate van significantie, en de kleinste significante verschillen (LSDwaarden) vermeld. Met letters zijn de significante verschillen aangeduid. 
Tabel 12. Gemiddelde stikstofopbrengst per ha per jaar voor de behandeling Stikstofbemesting. De overschrijdingskans ( $p$-waarde), als kengetal voor de mate van significantie, bedroeg 0,020 (significant) en het kleinste significante verschil (LSD-waarde) bedroeg 16,7 kg stikstof per ha.

Jaar Geen OWD's OWD's op sloot Pompgestuurde OWD's

\begin{tabular}{rrrrrrr}
\hline 2016 & 296 & a & 307 & a & 306 & a \\
\hline 2017 & 409 & c & 393 & bc & 382 & b
\end{tabular}

De resultaten laten een relatief groot jaareffect zien en een relatief klein effect van de behandeling Drainage in 2017. In dit jaar duidt de toepassing van onderwaterdrains op een lagere stikstofopbrengst, onafhankelijk van het stikstofbemestingniveau. Voor 2016 waren de stikstofopbrengsten nagenoeg gelijk. Voor de inzichtelijkheid zijn de resultaten ook in Figuur 14 weergegeven.

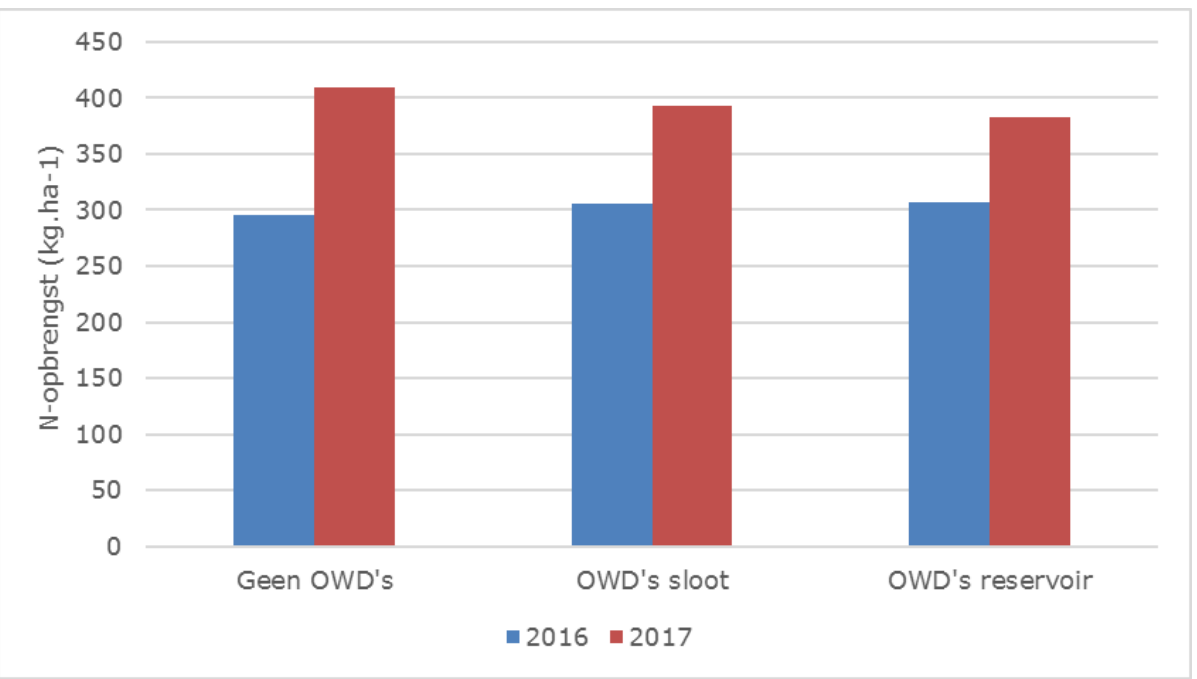

Figuur 14. Effect behandeling Drainage op de stikstofopbrengsten in 2016 en 2017.

De gemiddelde stikstofopbrengsten voor Jaar $x$ Stikstofbemesting $x$ Slootpeil staan in Tabel 13 . Daarbij staan de overschrijdingskansen ( $p$-waarden), als kengetal voor de mate van significantie, en de kleinste significante verschillen (LSD-waarden) vermeld. Met letters zijn de significante verschillen aangeduid.

Tabel 13. Gemiddelde stikstofopbrengst per ha per jaar voor de behandeling Stikstofbemesting. De overschrijdingskans ( $p$-waarde), als kengetal voor de mate van significantie, bedroeg 0,009 (sterk significant) en het kleinste significante verschil (LSD waarde) bedroeg 47,6 kg stikstof per ha.

\begin{tabular}{lrrrrr} 
Jaar & N-bemesting & Hoog slootpeil & & Laag slootpeil \\
2016 & N0 & 202 & $\mathrm{a}$ & 250 & $\mathrm{~b}$ \\
\hline & N1 & 366 & $\mathrm{~cd}$ & 393 & $\mathrm{~d}$ \\
\hline 2017 & N0 & 318 & $\mathrm{C}$ & 341 & $\mathrm{c}$ \\
\hline & N1 & 460 & $\mathrm{e}$ & 460 & $\mathrm{e}$
\end{tabular}

Het interactie-effect geeft aan dat het effect van Stikstofbemesting afhankelijk was van het Slootpeil en het Jaar. Het effect van Stikstofbemesting was in 2106 groter dan in 2017 en N1 was dit effect kleiner dan voor N0. De resultaten zijn tevens in Figuur 15 weergegeven. 


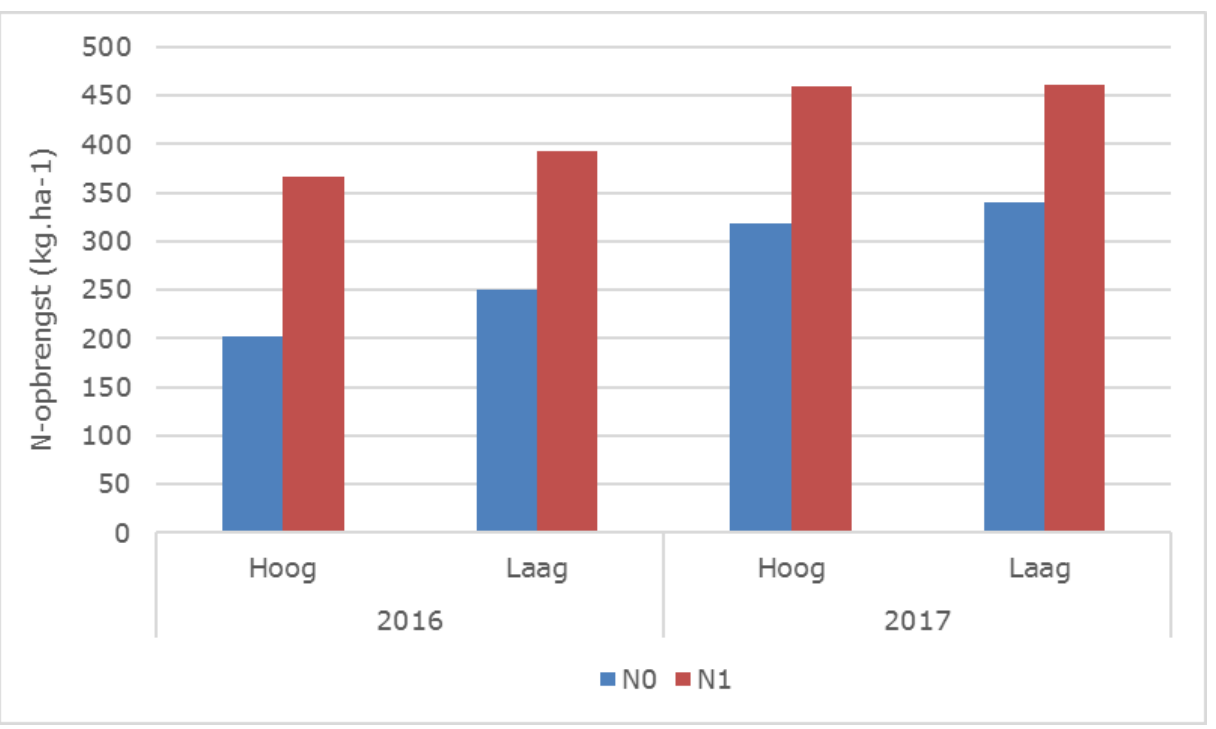

Figuur 15. Effect behandelingen Stikstofbemesting en Slootpeil op de stikstofopbrengsten in 2016 en 2017.

\subsection{Botanische samenstelling}

Op het eind van de proefperiode is de botanische samenstelling van de behandelingsobjecten bepaald (26-10-2017). Een verandering van de botanische samenstelling was vanwege de korte proefperiode van twee jaar niet te verwachten. De resultaten zijn vooral van belang voor het beoordelen van de gerealiseerde grasopbrengsten en stikstofgehaltes van het gras. Grote verschillen in grassoorten kunnen een aanwijzing zijn voor verschillen in opbrengst en kwaliteit van gras.

In Tabel 14 staan de resultaten van de kartering per proefperceel per drainbehandeling voor de meest voorkomende grassen. In Bijlage 8 staan de resultaten van de volledige kartering.

Tabel 14. Botanische samenstelling proefperceel 13 en 14 (hoog slootpeil) en 15 en 16 (laag slootpeil) voor de behandelingen Pompgestuurde drainage (a), Geen onderwaterdrains (b) en Onderwaterdrains op de sloot (c) gekarteerd op 26-10-2017.

\begin{tabular}{lcccccccccccccc} 
Datum, bezetting en & 13 & 13 & 13 & 14 & 14 & 14 & 15 & 15 & 15 & 16 & 16 \\
grassoort & $\mathrm{a}$ & $\mathrm{b}$ & $\mathrm{c}$ & $\mathrm{a}$ & $\mathrm{b}$ & $\mathrm{c}$ & $\mathrm{a}$ & $\mathrm{b}$ & $\begin{array}{c}16 \\
\mathrm{c}\end{array}$ & $\mathrm{b}$ & $\mathrm{c}$ \\
\hline Totale bezetting & 98 & 98 & 98 & 98 & 98 & 98 & 98 & 98 & 98 & 98 & 98 & 98 \\
\hline Engels raaigras & 57 & 57 & 61 & 53 & 58 & 51 & 55 & 54 & 48 & 69 & 67 & 69 \\
\hline timotheegras & + & + & + & + & + & + & 8 & 12 & 12 & 6 & 5 & 8 \\
\hline ruw beemdgras & 24 & 22 & 20 & 25 & 25 & 25 & 18 & 16 & 18 & 15 & 15 & 12 \\
\hline kweek & 3 & 2 & 3 & 5 & 3 & 4 & 2 & 1 & 2 & 1 & 2 & 1 \\
\hline fioringras & 2 & 3 & 2 & 3 & 2 & 4 & 1 & 1 & 1 & + & + & 1 \\
\hline straatgras & 12 & 15 & 12 & 8 & 8 & 10 & 6 & 8 & 8 & 5 & 8 & 6 \\
\hline
\end{tabular}

+ soort is wel aangetroffen, maar met $<1 \%$

Engels raaigras is landbouwkundige de best gewaardeerde grassoort, timothee is een goed gewaardeerde grassoort, ruwbeemd wordt matig gewaardeerd en kweek wordt zeer slecht gewaardeerd. Straatgras en fiorin worden slecht gewaardeerd. Binnen de percelen waren nauwelijks verschillen. Perceel 16 had een relatief hoog aandeel Engels raaigras, op perceel 15 en 16 kwam een substantieel aandeel timothee voor, in tegenstelling tot de perceel 13 en 14, en op perceel 13 was het aandeel straatgras relatief hoog. 


\subsection{Ontwikkeling voorzieningen pompaansturing}

\section{Besliscriteria}

Het grondwaterpeil was een belangrijke factor in de aansturing van het peil in het waterreservoir. Dit vereist inzicht in de actuele grondwaterstand. De monitoring hiervan vond plaats door middel van dagelijkse handmatige metingen en de inzet van automatische drukopnemers. De grondwaterstand wordt beïnvloed door neerslag, gewasverdamping en de mate van kwel of wegzijging. Neerslag heeft de meest directe invloed en daarom is naast de actuele grondwaterstand ook de neerslagverwachting als besliscriterium gehanteerd. Onnodig water aanvoeren of afvoeren kan hiermee voorkomen worden.

Volgens een matrix is de aan- afvoer van water afhankelijk gesteld van de actuele grondwaterstand en de verwachte neerslag (Tabel 4 in paragraaf 3.3). De classificatie van beide criteria is empirisch vastgesteld. Aanvankelijk werd een algoritme gehanteerd waarbij de beweging van het reservoirpeil min of meer omgekeerd evenredig was aan de beweging van het grondwaterpeil. Het bleek echter dat een grovere klassering met een 'aan-uit-systeem' praktischer uitvoerbaar was. Bovendien reageert de grondwaterstand bij dit systeem sneller door een groter drukverschil tussen het reservoirpeil en de grondwaterstand.

\section{Hardware}

Voor de uitvoering van het peilbeheer werden de waterreservoirs op perceel 14 en 15 voorzien van twee pompen; één pomp voor de aanvoer van water vanuit de sloot (infiltratie) en één pomp voor afvoer van water vanuit het reservoir (drainage). Voor de aansturing van de pompen is een voorziening ontwikkeld om het waterpeil in het waterreservoir te meten, zodat met peilmarges gewerkt kon worden om de pompen gericht aan en af kunnen te laten slaan. Deze peilmarges zijn instelbaar zodat een maximum- en minimumwaterpeil opgegeven kan worden. Het meten van het waterpeil gebeurt met een ultrasoonsensor (zie Figuur 16).

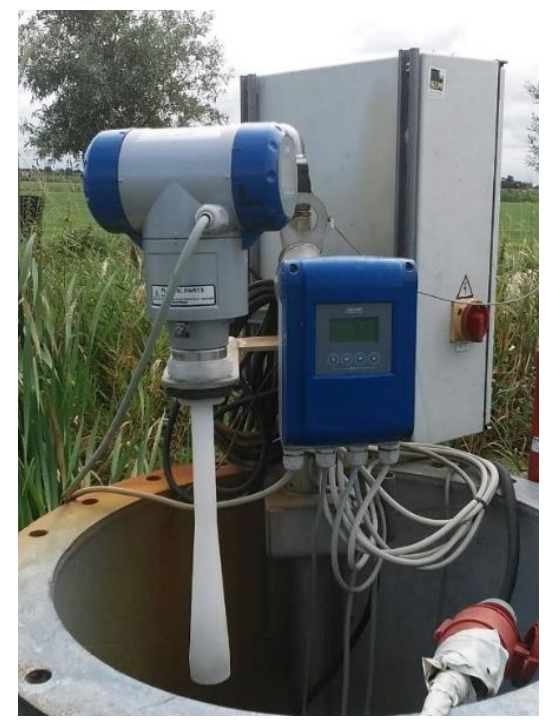

Figuur 16. Ultrasoonsensor (links) voor het meten van het waterpeil in het waterreservoir.

\section{Software}

Aanvankelijk werd het maximum- en minimumwaterpeil handmatig op de pompen (dus op locatie) ingegeven. In de loop van het project is hier een automatische voorziening voor geprogrammeerd in de vorm van een webservice, welke het mogelijk maakt om op afstand de pompen aan te sturen. Het interface van het programma voorziet in een keuzemenu voor het aan- en afvoeren van water, respectievelijk infiltreren en draineren, conform Tabel 4 waarin het peilregime staat gedefinieerd (zie Figuur 17). Elk vakje is een knop waarvoor de maximum- en minimumwaterpeilen zijn gedefinieerd, afhankelijk van de actuele grondwaterstand en de verwachte neerslag. De blauwe vakjes betreffen de instellingen voor infiltreren, de rode vakjes voor draineren en de grijze vakjes voor een neutrale stand waarin beide pompen uitstaan. De instellingen per knop beïnvloeden de sterkte van de regeling. 
Details Aansturing: Veenweidegebied

Klik op de vakken om de instellingen te veranderen

\begin{tabular}{|c|c|c|c|c|c|}
\hline \multirow[b]{2}{*}{$\begin{array}{l}\text { Neerslag } \\
\text { komende } \\
3 \text { dagen }\end{array}$} & \multicolumn{5}{|c|}{ Grondwaterpeil in $\mathrm{cm}$ onder het maaiveld } \\
\hline & 0.30 & $30-35$ & $35-40$ & $40-45$ & $>45$ \\
\hline Geen & $\begin{array}{l}\text { Drainage } \\
\text { Max }=50 \\
\text { Min }=40\end{array}$ & Vit & $\begin{array}{l}\text { Infiltratie } \\
\text { Max }=104 \\
\text { Min }=100\end{array}$ & $\begin{array}{l}\text { Infiltratie } \\
\text { Max }=103 \\
\text { Min }=100\end{array}$ & $\begin{array}{l}\text { Infiltratie } \\
\text { Max }=102 \\
\text { Min }=100\end{array}$ \\
\hline 0.10 & $\begin{array}{l}\text { Drainage } \\
\text { Max }=51 \\
\text { Min }=41\end{array}$ & $\begin{array}{l}\text { Drainage } \\
\text { Max }=41 \\
M i n=31\end{array}$ & Uit & $\begin{array}{l}\text { Infiltratie } \\
\operatorname{Max}=93 \\
\operatorname{Min}=90\end{array}$ & $\begin{array}{l}\text { Infiltratie } \\
\operatorname{Max}=92 \\
\operatorname{Min}=90\end{array}$ \\
\hline $10-25$ & $\begin{array}{l}\text { Drainage } \\
M a x=52 \\
M i n=42\end{array}$ & $\begin{array}{l}\text { Drainage } \\
\operatorname{Max}=42 \\
\operatorname{Min}=32\end{array}$ & $\begin{array}{l}\text { Drainage } \\
\text { Max }=32 \\
\text { Min }=22\end{array}$ & Uit & $\begin{array}{l}\text { Infiltratie } \\
\operatorname{Max}=84 \\
\operatorname{Min}=80\end{array}$ \\
\hline$>25$ & $\begin{array}{l}\text { Drainage } \\
\text { Max }=54 \\
\text { Min }=44\end{array}$ & $\begin{array}{l}\text { Drainage } \\
\text { Max }=44 \\
\text { Min }=34\end{array}$ & $\begin{array}{l}\text { Drainage } \\
\text { Max }=34 \\
\text { Min }=24\end{array}$ & $\begin{array}{l}\text { Drainage } \\
\text { Max }=24 \\
\text { Min }=14\end{array}$ & Uit \\
\hline
\end{tabular}

Terug

Figuur 17. Screenshot van webservice pagina waarin de maximum- en minimumpeilen in een waterreservoir kunnen worden ingesteld voor het aan- en afvoeren van water, respectievelijk infiltreren (blauwe vakjes) en draineren (rode vakjes), of een neutrale stand waarin geen van beide pompen werken (grijze vakjes).

Voor de aansturing van de pompen voorziet de webservice in een managementpagina waarop handmatig de gewenste instelling geselecteerd kan worden; zie gele knop in Figuur 18. Daarbij wordt het ingestelde maximum- en minimumwaterpeil getoond.

Een volgende stap is om de webservice automatisch de instellingen te laten kiezen (groene knop). Hiertoe moet een verbinding worden gemaakt met grondwaterstandsgegevens en met weerdata. Zie verder hoofdstuk 5 Discussie. 


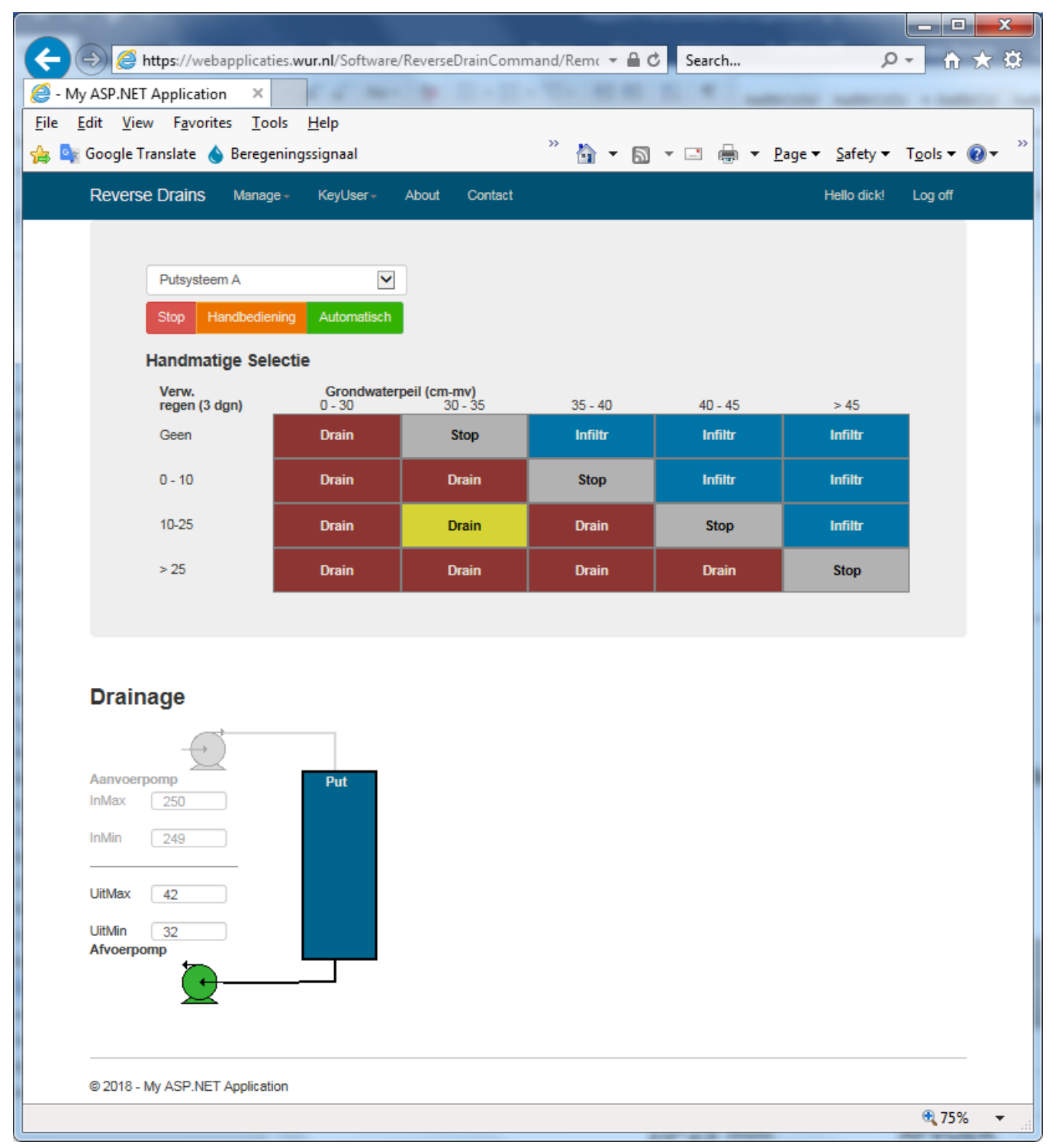

Figuur 18. Screenshot webservice pagina waarin de gewenste drainage (rode vakjes), infiltratieinstelling (blauwe vakjes) of neutrale stand (grijze vakjes) gekozen kan worden afhankelijk van de actuele grondwaterstand en de verwachte neerslag. Daarbij kan op deze pagina het systeem geheel uitgeschakeld worden, op handbediening gezet worden, of volledig automatisch laten draaien. Voor de laatste optie moten nog extra voorzieningen worden getroffen. 


\section{$5 \quad$ Discussie}

\section{Uitvoering peilaansturing}

In de proef werd de grondwaterstand op een constante hoogte van ongeveer $40 \mathrm{~cm}$ beneden maaiveld gehouden. Dit is een empirisch vastgesteld niveau, die geldt voor de betreffende proefpercelen. De ervaring heeft geleerd dat bij deze grondwaterstand de draagkracht voor de betreffende proefpercelen onder gemiddelde zomerse omstandigheden nog juist voldoende is. Het doel was echter niet om de uiterste grondwaterstand voor draagkracht te toetsen, maar om te zien of het grondwaterpeil op een constant niveau te houden, ongeacht de mate van neerslag en verdamping en de hoogte van het slootpeil. Voor de uiteindelijk optimalisatie van het verminderen van veenafbraak en dientengevolge de $\mathrm{CO}_{2}$-emissie, zou de bodemvochttoestand leidend moeten zijn (zie Hoofdstuk 7).

Voor de uitvoering van de peilaansturing in de waterreservoirs dienen goed gekozen referentiepeilbuizen gebruikt te worden, aangezien de grondwaterstanden lokaal behoorlijk kunnen variëren. Bij voorkeur meerdere buizen per perceel. Wanneer de grondwaterstanden in de referentiepeilbuizen afwijken van het perceelsgemiddelde zal de aansturing minder accuraat zijn.

De neerslagverwachtingen kwamen niet altijd uit waardoor soms later werd gereageerd met een peilaanpassing dan achteraf mogelijk was geweest. Tijdens forse neerslagpieken steeg het grondwaterpeil wel boven het gewenste niveau, echter de duur was aanmerkelijk korter dan die van de onderwaterdrains op de sloot.

\section{Effect onderwaterdrains}

Voor het bepalen van het effect van verschillende drainbehandelingen op de grondwaterstand zou idealiter in de veldproef de k-waarden binnen de percelen ongeveer gelijk moeten zijn. Dit was echter niet het geval en is in de praktijk lastig te realiseren door variatie tussen en binnen percelen. De situering van de twee peilniveaus en de aanwezigheid van elektriciteit maakten dat de betreffende percelen het meest geschikt waren voor het uitvoeren van het onderzoek.

Tussen de drainobjecten bestonden verschillen in maaiveldhoogte $(0-7 \mathrm{~cm})$ bij een gelijk slootpeil. Voor de interpretatie van verschillen in grondwaterstanden moet zodoende hier voor gecorrigeerd worden, om effecten op de grondwaterstand zoveel mogelijk toe te kunnen schrijven aan de drainbehandelingen. In principe kan één van de maaiveldhoogtes als referentie gekozen worden, maar dan wordt geen rekening gehouden met de invloed van drooglegging op het hydrologische systeem in de bodem. Als compromis zijn zodoende de grondwaterstanden weergegeven ten opzichte van de gemiddelde maaiveldhoogte van het betreffende perceel.

Op percelen 13, 14 en 16 nivelleerden Onderwaterdrains op de sloot het grondwaterstandsverloop ten opzichte van Geen onderwaterdrains. In het zomerhalfjaar daalde bij Onderwaterdrains op de sloot de grondwaterstand tot ongeveer 60 à $65 \mathrm{~cm}$ onder maaiveld, gelijk of hoger dan de grondwaterstanden bij Geen onderwaterdrains. Daar waar de grondwaterstand bij Onderwaterdrains op de sloot gelijk was aan die van Geen Onderwaterdrains was de grondwaterstand relatief hoog of was het verschil tussen het slootpeil en de grondwaterstand relatief klein. Dit was het geval op perceel 15, waardoor Onderwaterdrains op de sloot op dit perceel een gering effect had. Pompgestuurde onderwaterdrains hadden een extra drainerend en infiltrerend effect ten opzichte van Onderwaterdrains op de sloot. Dit betekent dat een groter drukverschil tussen oppervlaktepeil en grondwaterstand de water aan-en afvoer daadwerkelijk vergrootte. De infiltratie-effecten waren in 2017 groter dan in 2016 door een groter neerslagtekort in de zomerperiode. Tussen percelen verschilden de resultaten door verschillen in doorlatendheid. Zo had perceel 16 beduidend hogere k-waarden dan de andere percelen, waardoor de drainerende en infiltrerende werking op dit perceel relatief goed was.

\section{Gewenst slootpeil}

De hoeveelheden water die de waterreservoirs ingepompt werden tijdens een neerslagtekort waren bij het hoge slootpeil gemiddeld 2 à 3 keer kleiner dan bij het lagere slootpeil. Dit is enerzijds te verklaren door extra infiltratie vanuit de sloot bij een hoog peil en anderzijds door extra drainage 
vanuit de bodem naar de sloot bij een laag slootpeil. Daarbij is de doorlatendheid van perceel 16 (laag peil) relatief hoog, waardoor het watertransport gemakkelijker verloopt. In feite werd water rondgepompt vanuit de sloot in het waterreservoir, via de onderwaterdrains en de bodem terug naar de sloot. Bij pompgestuurde onderwaterdrains verdient het zodoende aanbeveling om het slootpeil ongeveer gelijk te laten zijn aan het streefpeil, in het geval van het onderzoek zou dat dus $40 \mathrm{~cm}$ beneden maaiveld geweest zijn.

Veenafbraak en $\mathrm{CO}_{2}$-emissie

Met de pompgestuurde onderwaterdrains kon de grondwaterstand in het zomerhalfjaar in de buurt van de $40 \mathrm{~cm}$ beneden maaiveld gehouden worden. Ten opzichte van onderwaterdrains op de sloot kan daarmee de maaivelddaling verder gereduceerd worden. Om de reductie van maaivelddaling en $\mathrm{CO}_{2}-$ emissie te bepalen is een ruwe schatting berekend met respectievelijk de formules 8 en 5 uit paragraaf 2.4. Deze formules gaan uit van de gemiddeld laagste grondwaterstand (GLG), welke berekend wordt op basis van minimaal 8 jaar. Gezien de korte duur van de proef kon dit niet en is als alternatief de LG3 berekend op basis van de drie laagste grondwaterstanden per kalenderjaar.

Voor Geen onderwaterdrains en Onderwaterdrains op de sloot waren de LG3's de laagste grondwaterstanden tijdens de drogere perioden. Voor Pompgestuurde onderwaterdrains is onderscheid gemaakt in de laagste standen in deze drogere perioden en in het gehele zomerhalfjaar. Aan de hand van de LG3's is een ruwe schatting van de maaivelddaling-en de $\mathrm{CO}_{2}$-emissiereductie berekend met respectievelijk de formules 8 en 5 uit paragraaf 2.4. De resultaten staan in Tabel 15.

Tabel 15. Berekende (ruwe) schatting van de maaivelddaling-en de $\mathrm{CO}_{2}$-emissiereductie op basis van de gemiddelde LG3 per onderwaterdrainbehandeling voor de proefperiode 2016-2017.

\begin{tabular}{|c|c|c|c|c|c|}
\hline Perceel & Behandeling & $\begin{array}{c}\text { LG3 (2016-2017) } \\
\text { (cm-mv) }\end{array}$ & $\begin{array}{c}\text { Maaivelddaling } \\
\text { (mm) }\end{array}$ & $\begin{array}{c}\mathrm{CO} 2 \\
\left(\mathrm{t} \mathrm{CO}_{2} \mathrm{ha}^{-1} \text { jaar }^{-1}\right)\end{array}$ & $\begin{array}{c}\text { Reductie } \\
\text { (\%) }\end{array}$ \\
\hline \multirow[t]{4}{*}{13} & 1. Geen OWD's & -61 & 8 & 18 & 0 \\
\hline & 2. OWD's op de sloot & -58 & 7 & 16 & 11 \\
\hline & 3. OWD's pompgestuurd - alleen droge perioden & -46 & 4 & 8 & 52 \\
\hline & 4. OWD's pompgestuurd - gehele zomerhalfjaar & -46 & 4 & 9 & 52 \\
\hline \multirow[t]{4}{*}{14} & 1. Geen OWD's & -60 & 8 & 17 & 0 \\
\hline & 2. OWD's op de sloot & -46 & 4 & 9 & 51 \\
\hline & 3. OWD's pompgestuurd - alleen droge perioden & -44 & 3 & 7 & 58 \\
\hline & 4. OWD's pompgestuurd - gehele zomerhalfjaar & -44 & 3 & 7 & 58 \\
\hline \multirow[t]{4}{*}{ Gem. hoog slootpeil } & 1. Geen OWD's & -61 & 8 & 17 & $\mathbf{0}$ \\
\hline & 2. OWD's op de sloot & -52 & 5 & 12 & 31 \\
\hline & 3. OWD's pompgestuurd - alleen droge perioden & -45 & 3 & 8 & 55 \\
\hline & 4. OWD's pompgestuurd - gehele zomerhalfjaar & -45 & 3 & 8 & 55 \\
\hline \multirow[t]{4}{*}{15} & 1. Geen OWD's & -59 & 7 & 17 & 0 \\
\hline & 2. OWD's op de sloot & -57 & 7 & 15 & 9 \\
\hline & 3. OWD's pompgestuurd - alleen droge perioden & -38 & 2 & 4 & 77 \\
\hline & 4. OWD's pompgestuurd - gehele zomerhalfjaar & -41 & 2 & 5 & 69 \\
\hline \multirow[t]{4}{*}{16} & 1. Geen OWD's & -78 & 12 & 28 & 0 \\
\hline & 2. OWD's op de sloot & -58 & 7 & 16 & 43 \\
\hline & 3. OWD's pompgestuurd - alleen droge perioden & -49 & 5 & 10 & 64 \\
\hline & 4. OWD's pompgestuurd - gehele zomerhalfjaar & -52 & 5 & 12 & 57 \\
\hline \multirow[t]{4}{*}{ Gem. laag slootpeil } & 1. Geen OWD's & -69 & 10 & 22 & $\mathbf{0}$ \\
\hline & 2. OWD's op de sloot & -58 & 7 & 16 & 26 \\
\hline & 3. OWD's pompgestuurd - alleen droge perioden & -44 & 3 & 7 & 70 \\
\hline & 4. OWD's pompgestuurd - gehele zomerhalfjaar & -46 & 4 & 9 & 63 \\
\hline \multirow[t]{4}{*}{ Gem. totaal } & 1. Geen OWD's & -65 & 9 & 20 & 0 \\
\hline & 2. OWD's op de sloot & -55 & 6 & 14 & 28 \\
\hline & 3. OWD's pompgestuurd - alleen droge perioden & -44 & 3 & 7 & 63 \\
\hline & 4. OWD's pompgestuurd - gehele zomerhalfjaar & -46 & 4 & 8 & 59 \\
\hline
\end{tabular}

De berekende gemiddelde schatting voor de reductie van maaivelddaling en $\mathrm{CO}_{2}$-emissie over de vier proefpercelen bedraagt $28 \%$ voor Onderwaterdrains op de sloot en $59 \%$ voor Pompgestuurde onderwaterdrains, uitgaande van de LG3 gebaseerd op de gehele zomerperiode en $63 \%$ uitgaande van de LG3 gebaseerd op uitsluitend de drogere perioden. Tussen beide slootpeilen verschilden de resultaten voor Onderwaterdrains op de sloot en Pompgestuurde onderwaterdrains. De resultaten staan in Figuur 19. De reductie van maaivelddaling en $\mathrm{CO}_{2}$-emissie is groter voor Pompgestuurde onderwaterdrains bij een laag slootpeil en groter voor Onderwaterdrains op de sloot bij een hoog slootpeil. 


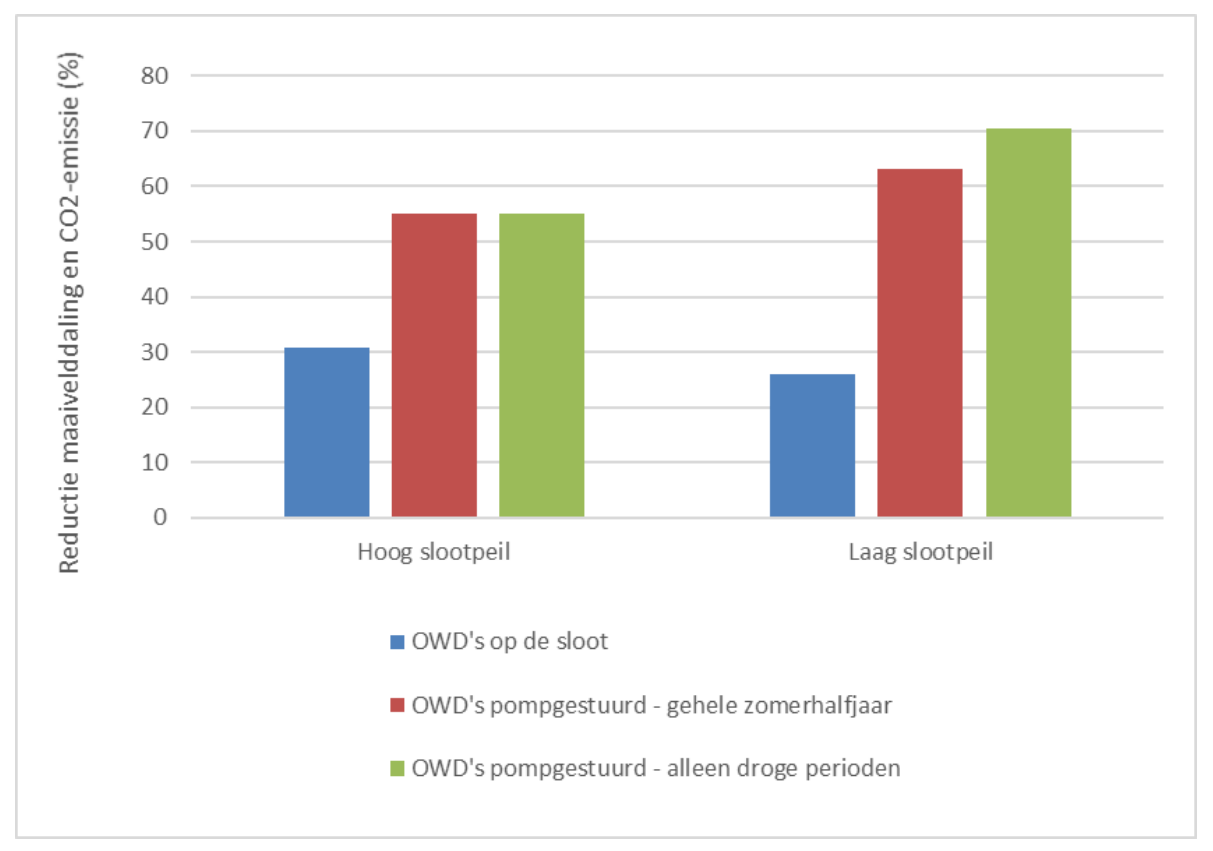

Figuur 19. Reductie maaivelddaling en $\mathrm{CO}_{2}$-emissie (\%).

De geschatte reductie van de maaivelddaling en $\mathrm{CO}_{2}$-emissie voor Onderwaterdrains op de sloot is voor het hoge slootpeil kleiner dan de halvering die op basis van eerdere onderzoeken als potentieel haalbaar wordt geacht bij een slootpeil van 35 à $40 \mathrm{~cm}$ beneden maaiveld. Voor perceel 14 werd in potentie deze reductie wel gehaald, maar op perceel 13 niet. Mogelijk kwam dit door de extra waterafvoer via een greppel die in het midden op het perceel ligt en naar een sloot met een lager slootpeil draineert. Niet duidelijk is waarom bij Onderwaterdrains op de sloot wel extra waterafvoer zou optreden en bij Geen onderwaterdrains niet. Naast het verschil tussen percelen was de onderzoeksperiode van twee jaar te kort om de potentiele reductie te kunnen toetsen.

Overigens kan de werkelijke maaivelddaling wel meer reduceren dan op basis van het verschil in grondwaterstanden verwacht wordt. Metingen van Van den Akker et al. (2007, 2010, 2012 en 2017) overtroffen de schattingen, mogelijk omdat bij onderwaterdrains de verzadigde zone boven het grondwater ook hoger komt te liggen en het effect van een hogere GLG versterkt wordt. Daarbij zijn de schattingen gebaseerd op grondwaterstanden gemeten in het midden tussen de drains, waardoor de gemiddelde grondwaterstand in droge perioden overschat wordt ten opzichte van de veldgemiddelde grondwaterstand. Bij slechts een gering hoger wordende GLG neemt de geschatte maaiveldaling en $\mathrm{CO}_{2}$-reductie sterk af. Dit geeft aan dat met scherp sturen op de laagste grondwaterstand in potentie de reductie aanzienlijk vergroot kan worden.

\section{Grasopbrengst}

In eerdere veldproeven met onderwaterdrains op KTC Zegveld (Hoving et al., 2008) en in polder Zeevang (Hoving et al., 2015) werden (verwachtte) significante verschillen tussen jaren en stikstofbemestingsniveaus gevonden, maar ook significante interactie-effecten gevonden voor Jaar $\mathrm{x}$ Slootpeil en Jaar x Onderwaterdrains. De gras- en stikstofopbrengsten waren negatief gecorreleerd met de hoogte van het slootpeil of het toepassen van onderwaterdrains (uitgezonderd nattere jaren) door een lagere stikstoflevering door de bodem. De stikstofopbrengst van de onbemeste objecten geeft de stikstoflevering van de bodem weer. Perceel 15 en 16 (laag peil) hadden een hoger aandeel landbouwkundig goed gewaardeerde grassoorten dan perceel 13 en 14 (hoog peil), maar daar kunnen de verschillen in opbrengst niet door verklaard worden. 
Inschatting economie

De berekende kosten en baten voor de toepassing van gangbare onderwaterdrains staan in Tabel 2 in paragraaf 2.3. Bij een investering van 1800 euro per ha bedragen de baten 54 euro per ha. Voor pompgestuurde onderwaterdrains ligt de investering hoger vanwege de extra aanlegkosten voor de collectordrain en het benodigde waterreservoir. Daarbij vraagt de aanschaf van pompen (aan- en afvoer) en een voorziening voor het regelen van het waterpeil in het waterreservoir een hogere investering. De meerkosten zijn op dit moment nog lastig te bepalen, aangezien de voorzieningen voor het toepassen van pompgestuurde onderwaterdrains nog in ontwikkeling zijn. Ook is het financiële plaatje afhankelijk van het aantal hectares dat met één systeem bediend kan worden. Geschat wordt dat ongeveer 5 ha haalbaar is. Om een indruk te krijgen hoe hoog de meerkosten mogen zijn, is het break even punt berekend waarbij de kosten en baten aan elkaar gelijk zijn. De resultaten staan in Tabel 16.

Tabel 16. Kosten en baten (break even) pompgestuurde onderwaterdrains ( $€ /$ ha) bij een drainafstand van $6 \mathrm{~m}$ op basis van de tarieven volgens KWIN (2018).

\begin{tabular}{|c|c|c|c|}
\hline \multicolumn{4}{|l|}{ Baten } \\
\hline Extra grasbenutting & 500 & (kg ds/ha) & \\
\hline Besparing kosten aankoop maïs & & $(€ /$ ha $)$ & 81,43 \\
\hline Voordeel voederwaarde weidegras & & $(€ /$ ha $)$ & 19,82 \\
\hline Voordeel extra weidedagen & 30 & $(€ /$ ha $)$ & 67,85 \\
\hline Totaal voordeel & & $(€ /$ ha $)$ & 171,00 \\
\hline \multicolumn{4}{|l|}{ Kosten } \\
\hline Jaarkosten $6,5 \%$ gedurende 20 jaar & & $(€ /$ ha $)$ & 169,00 \\
\hline Investering in pompgestuurde onderwaterdrains & $2.600,00$ & $(€ /$ ha $)$ & \\
\hline Verschil & & ( $€ /$ ha $)$ & 0,09 \\
\hline
\end{tabular}

De meerkosten ten opzichte van gangbare onderwaterdrains mogen 800 euro per ha bedragen om de kosten niet hoger te laten zijn dan de baten. Gesteld dat één systeem 5 ha kan bedienen dan mogen de totale investeringskosten 4.000 euro extra bedragen. Wanneer het mogelijk is om onder dit bedrag te blijven dan worden de baten hoger dan de kosten. Duidelijk is wel dat het te verwachten financiële rendement lager wordt.

\section{Draagkracht graszode}

De indruk bestaat dat op veengrond een dichte vitale graszode een hogere draagkracht geeft voor betreding en berijding met machines. Het sneller afvoeren van een overmaat aan vocht in de wortelzone kan een positief effect hebben op de vitaliteit en omvang van het wortelstelsel (minder afsterving en een grotere diepte). Dit zal op termijn moeten blijken; de proefperiode was te kort om dit effect waar te nemen. 


\section{Conclusies en aanbevelingen}

De conclusies van het onderzoek zijn als volgt:

- Pompgestuurde onderwaterdrains hebben een aantoonbaar effect op de grondwaterstand.

- Pompgestuurde onderwaterdrains zorgen voor zowel extra infiltratie als extra drainage.

- Het resultaat van de pompaansturing is onafhankelijk van het slootpeil.

- De wateraanvoer is echter bij het lage slootpeil 2,5 keer groter geweest dan bij een hoog slootpeil. De waterafvoer was nagenoeg gelijk.

- Alleen in 2017 hebben pompgestuurde onderwaterdrains een significant verlagend effect op de stikstofopbrengst; dit duidt op een lagere N-levering door reductie van de veenafbraak.

- De geschatte gemiddelde reductie van maaivelddaling en $\mathrm{CO}_{2}$-emissie voor pompgestuurde onderwaterdrains bedraagt 59 à $63 \%$ en was gevoelig voor de gerealiseerde grondwaterpeilen.

- Alleen door zeer scherp te sturen op de grondwaterstand kan de maaivelddaling en $\mathrm{CO}_{2}$-emissie fors terug gebracht worden.

- Pompaansturing vergroot de effectiviteit van de werking van onderwaterdrains aanzienlijk, echter door de hogere investeringskosten daalt het financiële rendement. Daarbij is bovendien extra arbeidsinspanning nodig voor de aansturing.

Het onderzoek leidt tot de volgende aanbevelingen:

- De referentiepeilbuizen, ter ondersteuning van het peilbeheer, dienen binnen een perceel bij voorkeur midden tussen greppels en midden tussen drainbuizen geplaatst te worden op een derde tot de helft van de perceelsbreedte, voor een voldoende representativiteit.

- Het gebruik van automatische drukopnemers biedt de mogelijkheid om de pompaansturing volledig te automatiseren. Het advies is om meerdere automatische drukopnemers per perceel of kavel in te zetten, zodat bij storing waarnemingen beschikbaar blijven en de aansturing niet stagneert.

- Om het overzicht te behouden vergt het inzetten van automatische drukopnemers op bedrijfsschaal een goede organisatie van data. Dit betreft identificatie van de sensoren gekoppeld aan een locatie in het veld en inzicht in de waarnemingen van de sensor.

- Om bij infiltreren verlies van water naar belendende sloten te voorkomen dient het slootpeil ingesteld te worden op de gemiddelde gewenste grondwaterstand (streefpeil). 


\section{$7 \quad$ Vervolg}

Een volgende stap in de ontwikkeling van pompgestuurde onderwaterdrains is het automatisch aansturen van de pompen en het verfijnen van de aansturing met inzicht in draagkracht van de graszode en het verminderen van $\mathrm{CO}_{2}$-emissie. Het uitgevoerde onderzoek (voorliggende rapport) heeft de bouwstenen voor een werkend besturingssysteem geleverd. Het geheel is echter nog niet geschikt voor uitrol in de praktijk. Essentieel is dat het geheel 'webbased' wordt met een directe koppeling van data tussen percelen, waterreservoirs, pompen en automatische drukopnemers, waarbij ook ruimtelijk het overzicht wordt behouden. In het huidige programma moeten de relaties tussen grondwaterstanden en het waterreservoirpeil worden ingebracht evenals de aansturing van de pomp in de waterput. Dit zijn nu nog allemaal losse componenten die in één programma geïntegreerd moeten worden. De connectie met weerdata en automatische metingen van grondwaterstanden vraagt om de inzet van een internetplatform, zoals Akkerweb (https://akkerweb.eu/nl-nl/) dat hiervoor ingezet gaat worden.

Tevens is het gewenst om het effect van precisiewatermanagement op draagkracht en $\mathrm{CO}_{2}$-emissie inzichtelijk te maken. In een vervolgproject wordt een webapplicatie gerealiseerd waarmee melkveehouders op veengrond pompgestuurde onderwaterdrains optimaal kunnen inzetten voor het minimaliseren van maaivelddaling, $\mathrm{CO}_{2}$-emissie en het verbeteren van draagkracht. In het onderzoek is gestuurd op een streefpeil voor de grondwaterstand, maar in feite is het de vochttoestand van de bovengrond die bepalend is voor de mate van veenafbraak en draagkracht. Cruciaal is dat de bovengrond voldoende vochtig blijft om zuurstofintreding te beperken en niet te nat wordt voor het behoud van draagkracht. Eigenlijk moet dus niet op de grondwaterstand, maar op de vochttoestand van de bovengrond gestuurd worden. Daarbij kunnen grondwaterstanden gewenst zijn die boven het tot nu toe gehanteerde streefpeil van $40 \mathrm{~cm}$ liggen. Het zal moet blijken of dit mogelijk is. De inzet is om hiermee bodemdaling en $\mathrm{CO}_{2}$-emissie verder te verminderen.

Als tool voor precisiewatermanagement wordt een bestaand bodemvochtmodel doorontwikkeld dat ingezet wordt voor BeregeningsSignaal van de ZLTO. Dit model wordt geherprogrammeerd om op Akkerweb connecties te kunnen maken met de perceelsregistratie van RVO, geodata (bodem en hydrologie), weerdata en sensordata. De relatief eenvoudige rekenkern in het huidige programma, voor het berekenen van de bodemvochtbalans, wordt in samenwerking met Wageningen Environmental Research vervangen door het model (WatBal) dat beter toegerust is op complexe hydrologische situaties, zoals dat voor veengrond het geval is. Een voordeel is dat het model ook een schatting geeft de grondwaterstand, wat de mogelijkheid geeft om deze te toetsen aan metingen in het veld. Een eerste inventarisatie naar de potentie van het verbeterde bodemvochtmodel is uitgevoerd. De voorspelde bodemvochttoestand en grondwaterstand is vergeleken met respectievelijk bodemvochtmetingen en grondwaterstandsmetingen voor een veenweideperceel op KTC Zegeveld in 2015 en 2016. De resultaten staan in Figuur 20 en laten zien dat het model de potentie heeft om de werkelijke bodemvochttoestand en grondwaterstand goed te benaderen. Met een dergelijk bodemvochtmodel wordt niet alleen de actuele situatie ingeschat, maar kan ook de weersverwachtingstermijn doorgerekend worden. Daarmee wordt het model voorspellend, wat het gemakkelijker maakt om te anticiperen op de weersverwachting. 


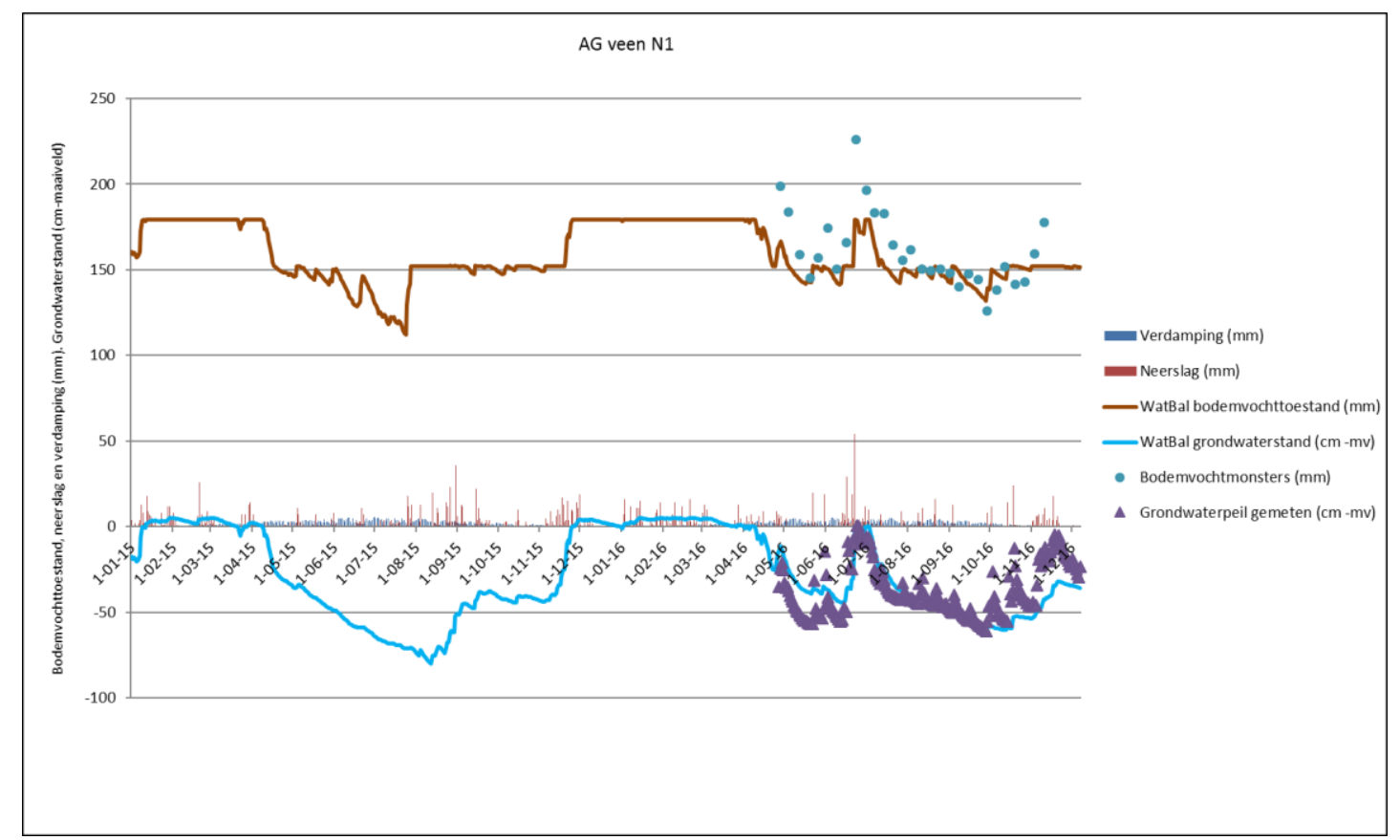

Figuur 20. Berekende bodemvochtbalans en grondwaterstand vergeleken met bodemvochtbepalingen en grondwaterstandsmetingen voor een veenweideperceel op KTC Zegveld in 2015 en 2016. 


\section{Bronnen}

Akker, J.J.H. van den, 2005. Maaivelddaling en verdwijnende veengronden. In: Veenweide $25 x$ belicht; een bloemlezing van het onderzoek van Wageningen UR. - Wageningen : Alterra, 2005 - p. 11 $-13$.

Akker, J.J.H. van den, J. Beuving, R.F.A. Hendriks en R.J. Wolleswinkel, 2007. Maaivelddaling, afbraak en $\mathrm{CO} 2$ emissie van Nederlandse veenweidegebieden. Leidraad Bodembescherming, Sdu, Den Haag, 32 blz.

Akker, J.J.H. van den, P.J. Kuikman, F. de Vries, I. Hoving, M. Pleijter, R.F.A. Hendriks, R.J. Wolleswinkel, R.T.L. Simões and C. Kwakernaak, 2008. Emission of CO2 from agricultural peat soils in the Netherlands and ways to limit this emission. In: Farrell, C and J. Feehan (eds.), 2008. Proceedings of the 13th International Peat Congress After Wise Use - The Future of Peatlands, Vol. 1 Oral Presentations, Tullamore, Ireland, 8-13 june 2008. International Peat Society, Jyväskylä, Finland. ISBN 0951489046. pp 645-648.

Akker, J.J.H. van den, R.F.A. Hendriks, I.E. Hoving en M. Pleijter, 2010. Toepassing van onderwaterdrains in veenweidegebieden. Effecten op maaivelddaling, broeikasgasemissies en het water. Werkgemeenschap voor Landschapsonderzoek (WLO), Utrecht, Landschap 27/3, 137-149

Akker, J.J.H. van den, R.F.A. Hendriks and M. Pleijter, 2012. CO2 emissions of peat soils in agricultural use: calculation and prevention. Proc. of the 19th Conference of the Int. Soil Tillage Res.

Org.wWw.ISTRO.org

Akker, J.J.H. van den, R.F.A. Hendriks, I.E. Hoving, J. van Kleef, B. Meerkerk, M. Pleijter en A. van den Toorn, 2013. Pilot onderwaterdrains Krimpenerwaard. Wageningen, Alterra Wageningen UR, Alterrarapport 2466.

Akker, J.J.H. van den, R.F.A. Hendriks, 2014. Hogere grondwaterstanden voor veenweiden. Veenweiden: Aangepast watermanagement noodzakelijk voor beperking veenafbraak. Bodem 6-2014, blz 7-9

Van den Akker, J.J.H., R.F.A. Hendriks, 2017. Diminishing peat oxidation of agricultural peat soils by infiltration via submerged drains. FAO 2017. Proceedings of the Global Symposium on Soil Organic Carbon 2017. Food and Agriculture Organization of the United Nations. Rome, Italy. pp. 436-439. http://www.fao.org/documents/card/en/c/d6555d8d-1b19-4c04-a25d-74474e6c0a11/

Akker, J.J.H. van den, et al 2018, in voorbereiding. Maaivelddaling veenweidegebieden: monitoring en metingen aan percelen met en zonder onderwaterdrains.

Beuving, J. en J.J.H. van den Akker, 1996. Maaiveldsdaling van veengrasland bij twee slootpeilen in de polder Zegvelderbroek. Vijfentwintig jaar zakkingsmetingen op het ROC Zegveld. Wageningen, DLOStaring Centrum. Rapport 377. 158 blz.

Couwenberg, J., Hooijer, A., 2013. Towards robust subsidence-based soil carbon emission factors for peat soils in south-east Asia, with special reference to oil palm plantations. Mires and Peat, Volume 12 (2013), Article 01, 1-13. http://www.mires-and-peat.net/, ISSN 1819-754X

Eggelsmann, R. 1976. Peat consumption under influence of climate, soil condition and utilization. In: Proceedings of the fifth international peat congress, vol 1. Poznan, Poland, pp 233-247 Genstat Eighteenth Edition. VSN International Ltd, 2015

Grønlund, A., A. Hauge, A. Hovde, D.P. Rasse, 2008. Carbon loss estimates from cultivated peat soils in Norway: a comparison of three methods. Nutr Cycl Agroecosyst (2008) 81:157-167 
Hendriks, R.F.A., Vermeulen, J., 1997. Effect of temperature of the decomposition of organic matter in Dutch peat soils. In: Schmilewski, G. (eds). Peat in horticulture; it's use and sustainability. Jyskä (Finland), IPS, pp. 156-162.

Hendriks, R.F.A., Wolleswinkel, R.J. and Van den Akker, J.J.H., 2008. Predicting greenhouse gas emission in peat soil depending on water management with the SWAP-ANIMO model. In: Farrell, C and J. Feehan (eds.), 2008. Proceedings of the 13th International Peat Congress After Wise Use - The Future of Peatlands, Vol. 1 Oral Presentations, Tullamore, Ireland, 8-13 june 2008. International Peat Society, Jyväskylä, Finland. ISBN 0951489046. pp 583-586.

Hendriks, R.F.A., J.J.H. van den Akker, K. van Houwelingen, J. van Kleef, M. Pleijter en A. van den Toorn, 2013. Pilot onderwaterdrains Utrecht. Wageningen, Alterra Wageningen UR. Alterra-rapport 2479.

Hoving, I.E., G. André, J.J.H. van den Akker en M. Pleijter, 2008. Hydrologische en landbouwkundige effecten gebruik 'onderwaterdrains' op veengrond. Lelystad, Animal Sciences Group van WUR. Rapport 102.

Hoving, I.E., P. Vereijken, K. van Houwelingen en M. Pleijter, 2013. Hydrologische en landbouwkundige effecten toepassing onderwaterdrains bij dynamisch slootpeilbeheer op veengrond. Lelystad, Wageningen-UR Livestock Research. Rapport 719.

Hoving, I.E., H. Massop, K. van Houwelingen, J.J.H. van den Akker en J. Kollen, 2015. Hydrologische en landbouwkundige effecten toepassing onderwaterdrains in polder Zeevang; Vervolgonderzoek gericht op de toepassing van een zomer- en winterpeil. Wageningen, Wageningen UR (University \& Research centre) Livestock Research. Livestock Research Rapport 875.

Hoving, I.E. en J.A. de Vos, 2007. Gevolgen van verminderde drooglegging voor melkveebedrijven in de Krimpenerwaard. Verbeterde berekeningen voor 10 weerjaren. Lelystad, Animal Sciences Group van WUR. Rapport 88

Kroes, J.G. and J.C. van Dam (eds), 2003. Reference Manual SWAP version 3.0.3. Wageningen, Alterra, Green World Research. Alterra-report 773. Reference Manual SWAP version 3.0.3.doc.

Kuikman, P.J., van den Akker, J.J.H. \& de Vries, F., 2005. Emissie van $\mathrm{N}_{2} \mathrm{O}$ en $\mathrm{CO}_{2}$ uit organische landbouwbodems. Wageningen, Alterra. Alterra Report 1035-2, 66 pp.

KWIN, 2018. Kwantitatieve informatie veehouderij 2018-2019. Wageningen, Wageningen Livestock Research.

Schothorst, C. J., 1977: Subsidence of low moor peat soils in the Western Netherlands, Geoderma, 17, 265-291.

Schothorst, C.J., 1982. Drainage and Behaviour of Peat Soils. Proc. Symp. on Peatlands below Sea Level. 1982. ILRI publication 30, Wageningen, The Netherlands: 130-163

Van den Pol-van Dasselaar, A., A.P. Philipsen en M.H.A. de Haan, 2013. Economisch weiden. Lelystad, Wageningen UR Livestock Research. Rapport 679.

Vermeulen, J. en R.F.A. Hendriks, 1996. Bepaling van afbraaksnelheden van organische stof in laagveen. Ademhalingsmetingen aan ongestoorde veenmonsters in het laboratorium. Wageningen, DLO-Staring Centrum. Rapport 288. 124 blz. 


\section{Bijlage 1 Bodeminventarisatie}

Gevoeligheidsanalyse

Om het effect van eventuele fouten in de waarnemingen op de k-waarde te onderzoeken is een beperkte gevoeligheidsanalyse uitgevoerd. Hierbij zijn de volgende effecten onderzocht:

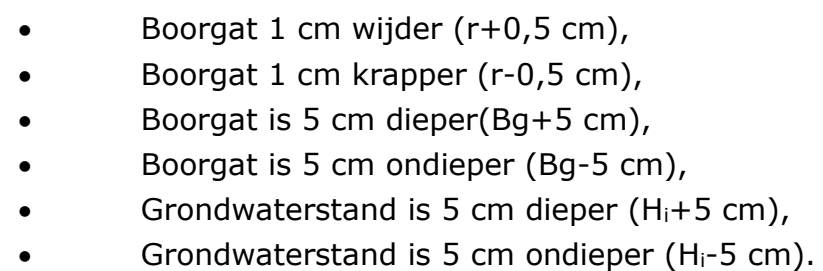

De mediane k-waarden van de gevoeligheidsanalyse per proefperceel (voor en achter) staan in Tabel 1.

Tabel 1. Mediane k-waarden ( $m$ per dag) gevoeligheidsanalyse boorgatmetingen per locatie

\begin{tabular}{|c|c|c|c|c|c|c|c|c|c|}
\hline & $\mathbf{k}_{\mathbf{g e m}}$ & $\mathbf{K}_{\mathbf{g e m}}$ & $\mathbf{K}_{\mathbf{g e m}}$ & $\mathbf{K}_{\mathbf{g e m}}$ & $\mathbf{k}_{\mathbf{g e m}}$ & $\mathbf{K}_{\mathbf{g e m}}$ & $\mathbf{K}_{\mathbf{g e m}}$ & Max & Min \\
\hline PR13_a & 0.14 & 0.17 & 0.12 & 0.13 & 0.16 & 0.17 & 0.12 & 0.17 & 0.12 \\
\hline PR13_V & 0.04 & 0.05 & 0.04 & 0.04 & 0.05 & 0.05 & 0.04 & 0.05 & 0.04 \\
\hline PR14_a & 0.17 & 0.20 & 0.14 & 0.15 & 0.19 & 0.21 & 0.14 & 0.21 & 0.14 \\
\hline PR15_a & 0.11 & 0.13 & 0.10 & 0.10 & 0.13 & 0.13 & 0.10 & 0.13 & 0.10 \\
\hline PR15_V & 0.18 & 0.21 & 0.15 & 0.16 & 0.20 & 0.22 & 0.15 & 0.22 & 0.15 \\
\hline PR16_a & 0.46 & 0.54 & 0.38 & 0.42 & 0.50 & 0.55 & 0.39 & 0.55 & 0.38 \\
\hline
\end{tabular}

De gevoeligheidsanalyse laat zien dat de grootte van de k-waarde enigszins wordt beïnvloed door fouten in de boorgatdiameter, diepte boorgat of uitgangsgrondwaterstand maar dat de grootteorde hetzelfde blijft. Voor het drainageadvies zijn berekeningen gedaan voor k-waarden van 0,04 $\mathrm{m}$ per dag (minimum), 0,16 m per dag (mediaan) en 0,46 m per dag (maximum).

\section{Drainageadvies}

Uitgangspunten voor het drainageadvies:

1. Profielopbouw. Voor het opstellen van het drainageadvies is uitgegaan van een gemiddeld profiel voor alle percelen:

- $600 \mathrm{~cm}$ veen

- zandondergrond

2. Uitholling grondwaterstand $(\mathrm{m}) \max 10 \mathrm{~cm}$.

3. Infiltratie om de verdamping te compenseren ter grootte van $3 \mathrm{~m}$ per dag gemiddeld over een decade uitgaande van een maximale verdamping van $5 \mathrm{~m}$ per dag.

4. Drains worden in de veenlaag gelegd met een dikte $(\mathbf{D})=6,0 \mathrm{~m}$.

5. Doorlatendheid. In de formule van Hooghoudt wordt onderscheid gemaakt tussen de doorlatendheid boven $\left(\mathbf{k}_{\mathbf{1}}\right)$ en onder drainniveau $\left(\mathbf{k}_{\mathbf{2}}\right)$. Voor de berekening is uitgegaan dat deze gelijk zijn. Wel is gekeken wat het effect is van het verschil in mediane waarden tussen de 4 proefpercelen.

Voor het bepalen van de drainafstand $(\mathbf{L})$ is gebruik gemaakt van de formule van Hooghoudt toegepast op een infiltratiesituatie, d.w.z. omgekeerde drainage. Hierbij dient te worden opgemerkt 
dat de formule van Hooghoudt bij voorkeur wordt toegepast als de doorlatendheid van de bovenste laag groter is of gelijk is aan die van de onderste laag, hetgeen aangenomen is.

Equivalentlaag(d): $\quad d=\frac{D}{1+\frac{8 D}{\pi L} \operatorname{Ln} \frac{D}{\pi r}}$

Drainafstand $(L)$

$$
L^{2}=\frac{8 k_{2} d m+4 k_{1} m^{2}}{q}
$$

De dikte van de equivalente laag (d), waarmee de radiale weerstand in rekening wordt gebracht, in relatie tot de drainafstand en de draindiameter is weergegeven in Figuur 1. De dikte van de equivalente laag varieert tussen de 0,4 en 1,0 m voor diameters (2r) van 50, 60, 80 en $100 \mathrm{~mm}$ en voor drainafstanden (L) variërend van 4-12 $\mathrm{m}$.

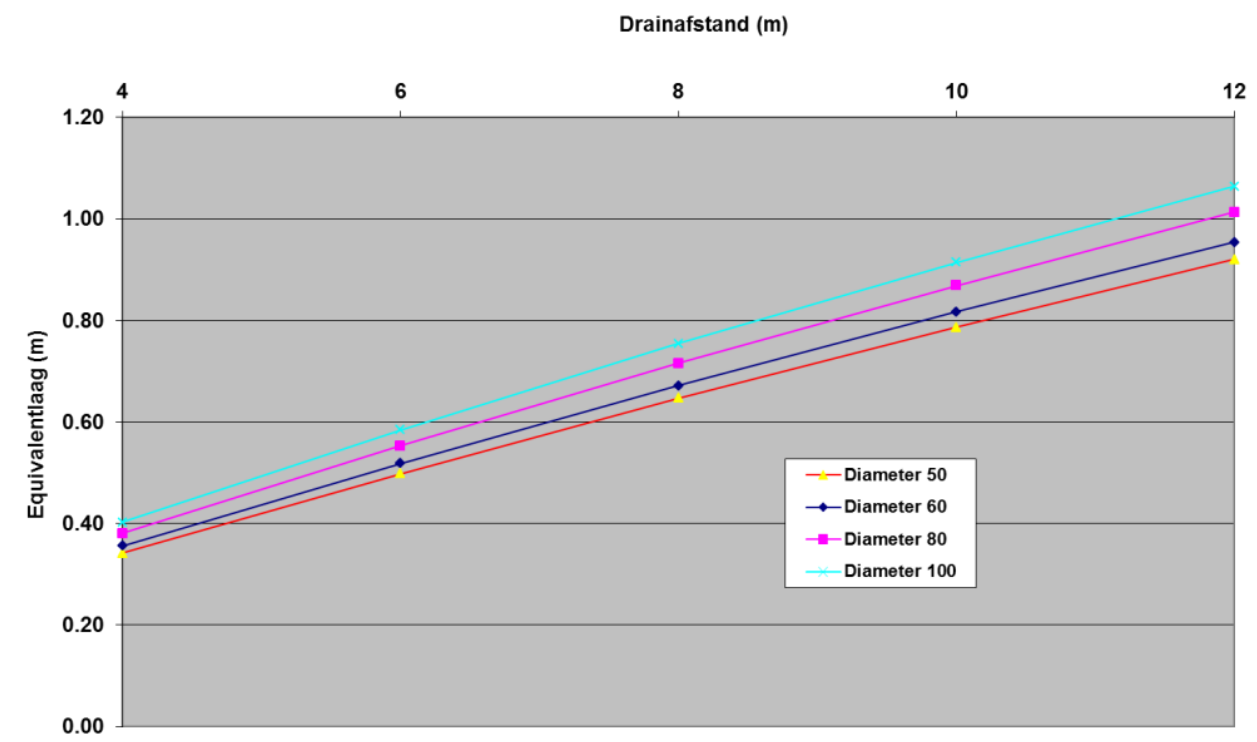

Figuur 1. Dikte equivalente laag $(m)$ in relatie tot de drainafstand en draindiameter.

Geringe k-waarde van 0,04 m per dag

Bij een uitholling van $0,1 \mathrm{~m}$ is de infiltratie kleiner dan $1 \mathrm{~m}$ per dag, bij een grotere uitholling van $0,2 \mathrm{~m}$ zal de infiltratie toenemen naar $1,8-2,0 \mathrm{~m}$ per dag. Bij een uitholling van 0,3 $\mathrm{m}$ en een drainafstand van $4 \mathrm{~m}$ kan er 3-3.3 m per dag kunnen infiltreren. De infiltratie in $\mathrm{m}$ per dag in relatie tot de drainafstand en draindiameter bij $\mathrm{k}=0,04 \mathrm{~m}$ per dag en een uitholling van $0,3 \mathrm{~m}$ is weergegeven in Figuur 2. 


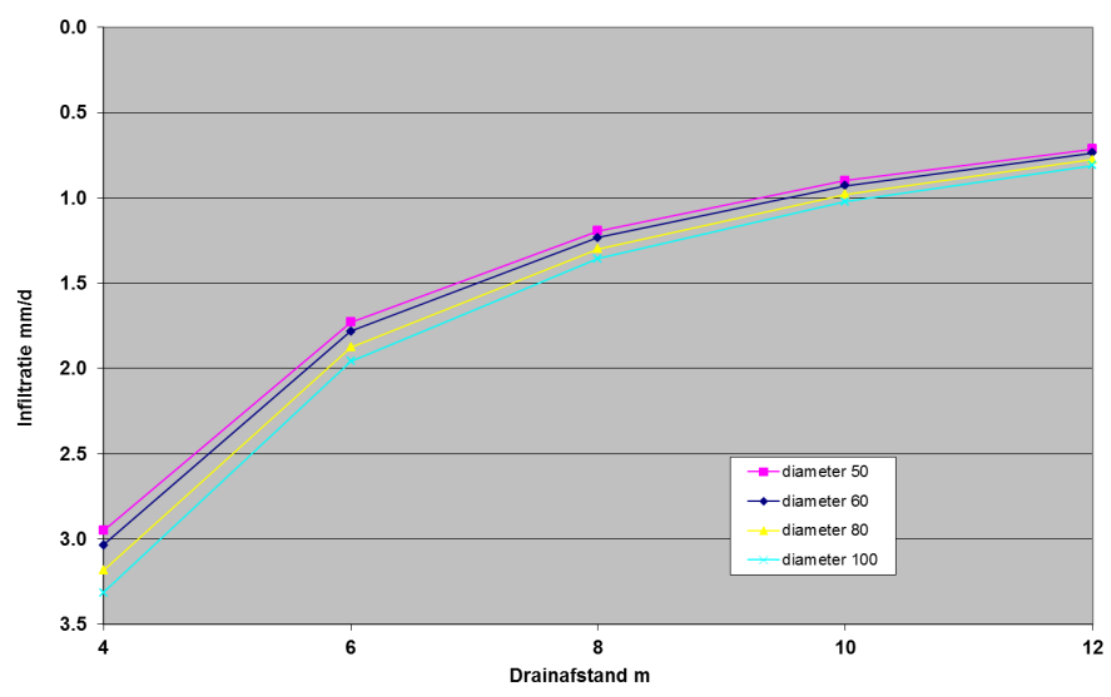

Figuur 2. Infiltratie in $m$ per dag in relatie tot de drainafstand en draindiameter bij $k=0,04 \mathrm{~m}$ per dag bij een uitholling van $0,3 \mathrm{~m}$.

\section{Mediane $k$-waarde van 0,16 m per dag}

Bij een uitholling van $0,1 \mathrm{~m}$ is de infiltratie 3.1 tot $3.6 \mathrm{~m}$ per dag bij een drainafstand van $4 \mathrm{~m}$, bij een drainafstand van $6 \mathrm{~m}$ bedraagt de infiltratie 2- $2.3 \mathrm{~m}$ per dag. Bij een iets grotere uitholling van 0,15 $\mathrm{m}$ bedraagt de infiltratie bij een drainafstand van $6 \mathrm{~m} \mathrm{3.0-3.5} \mathrm{m} \mathrm{per} \mathrm{dag.} \mathrm{De} \mathrm{infiltratie} \mathrm{in} \mathrm{m}$ per dag in relatie tot de drainafstand en draindiameter bij $\mathrm{k}=0,16 \mathrm{~m}$ per dag staat in Figuur 3.

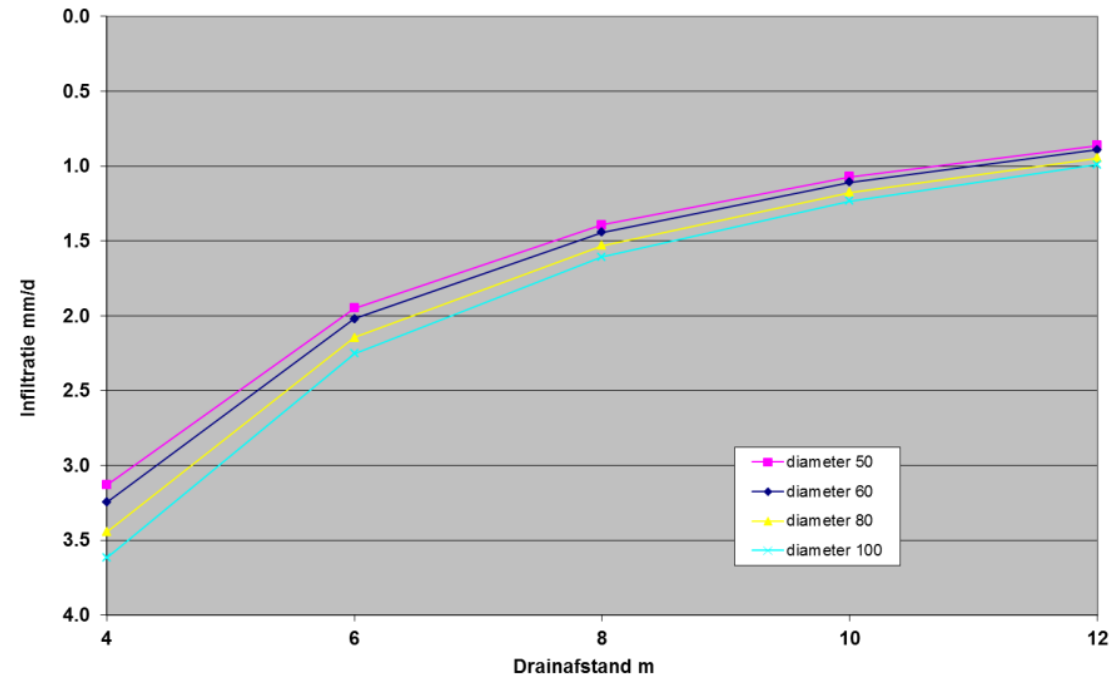

Figuur 3. Infiltratie in $m$ per dag in relatie tot de drainafstand en draindiameter bij $k=0,16 \mathrm{~m}$ per dag.

\section{Maximale $k$-waarde van 0,46 m per dag}

Bij een uitholling van $0,1 \mathrm{~m}$ is de infiltratie ruim groter dan $3 \mathrm{~m}$ per dag bij een drainafstand van $6 \mathrm{~m}$. De infiltratie in $\mathrm{mm} / \mathrm{d}$ in relatie tot de drainafstand en draindiameter bij $\mathrm{k}=0,46 \mathrm{~m}$ per dag staat in Figuur 4. 


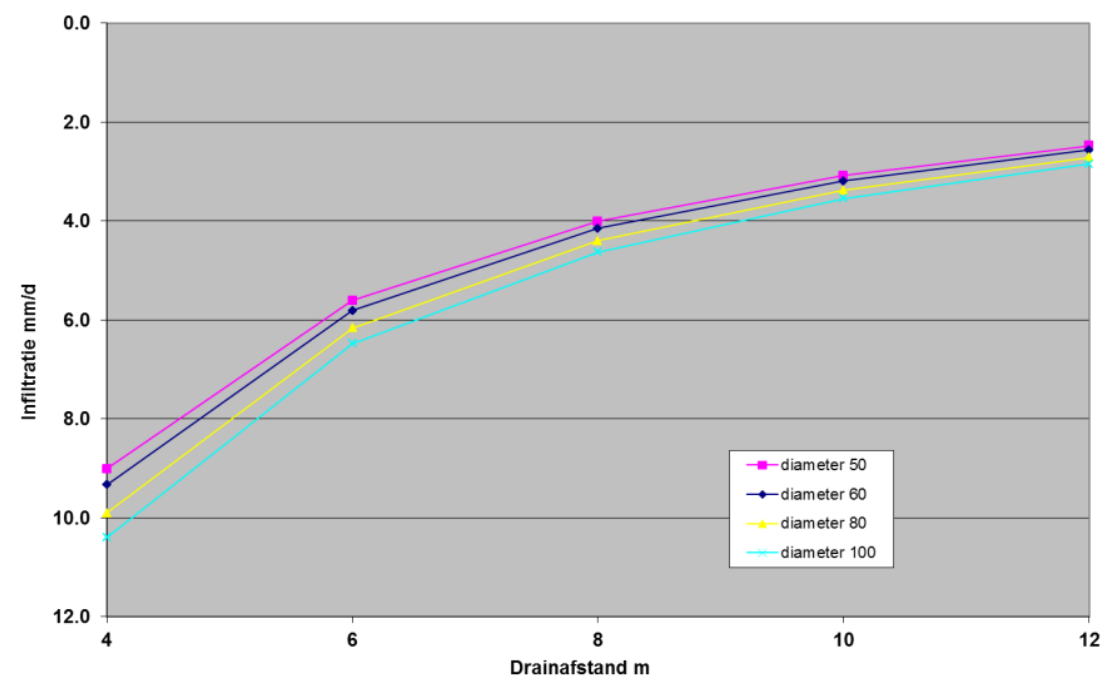

Figuur 6. Infiltratie in $m$ per dag in relatie tot de drainafstand en draindiameter bij $k=0,46 \mathrm{~m}$ per dag.

De drainage is aangelegd met een drainafstand van $6 \mathrm{~m}$. De drains liggen op de percelen met het hoge peil (perceel $13-14$ ) op $65-70 \mathrm{~cm}$ beneden maaiveld en op de percelen met het lage peil (perceel $15-16$ ) op 70-75 $\mathrm{cm}$ beneden maaiveld. Uitgaande van de mediane k-waarde is de drainafstand van $6 \mathrm{~m}$ net niet voldoende om bij een uitholling van $10 \mathrm{~cm}$ een infiltratie van $3 \mathrm{~m}$ per dag te realiseren. Als de eis met betrekking tot de uitholling op $0,15 \mathrm{~m}$ gesteld wordt, dan is $6 \mathrm{~m}$ wel voldoende. Door variatie in $\mathrm{k}$-waarden verschilt mogelijk de infiltratie per locatie.

Samengevat zijn de resultaten als volgt:

- De gevonden k-waarden variëren enigszins tussen de verschillende locaties, van 0,04 m per dag tot $0,46 \mathrm{~m}$ per dag met een mediane waarde van $0,16 \mathrm{~m}$ per dag.

- De drainage is reeds aangelegd, het betreft peilgestuurde drainage. De toegepaste draindiepte op de twee percelen met het hoge peil (perceel 13-14) is 50-60 cm-mv en op de percelen met het lage peil (perceel 15-16) ca. $70 \mathrm{~cm}$-mv, de drainafstand op alle percelen is $6 \mathrm{~m}$.

- Uitgaande van de mediane $\mathrm{k}$-waarde van $0,16 \mathrm{~m}$ per dag is de drainafstand van $6 \mathrm{~m}$ net niet voldoende om bij een uitholling van $10 \mathrm{~cm}$ een infiltratie van $3 \mathrm{~m}$ per dag te realiseren. Als de eis $\mathrm{m}$.b.t. tot de uitholling op $0,15 \mathrm{~m}$ gesteld wordt, dan is $6 \mathrm{~m}$ voldoende.

- Door variatie in $\mathrm{k}$-waarde zal de infiltratie kunnen verschillen per locatie. 


\section{Bijlage 2 Plattegrond proeflocatie}

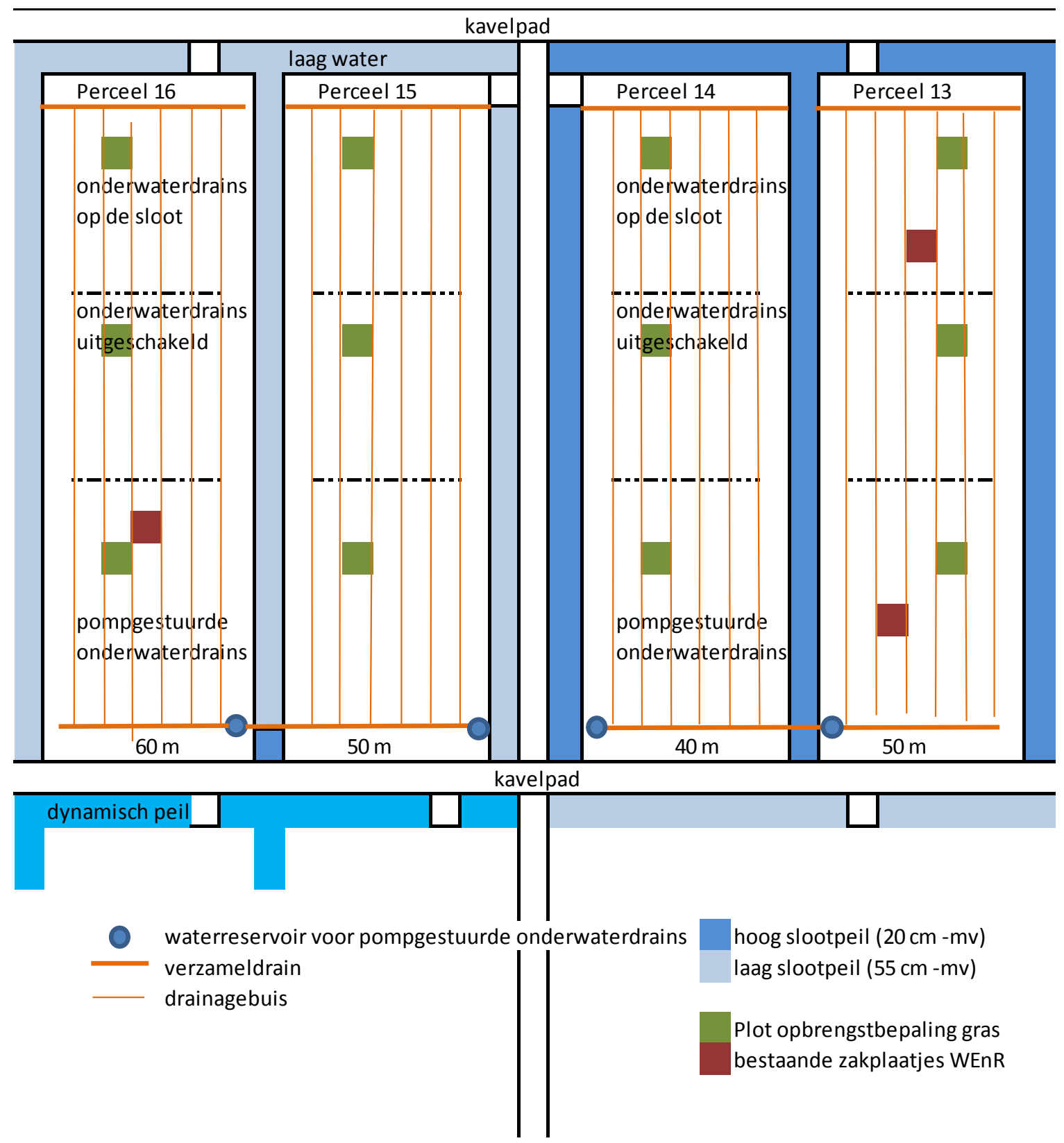

Figuur 1. Schematische schets inrichting proefpercelen (13-16) met de behandelingen (1) Geen onderwaterdrains, (2) Onderwaterdrains op de sloot en (4) Pompgestuurde onderwaterdrains bij een hoog en een laag slootpeil van respectievelijk 20 en $55 \mathrm{~cm}$ beneden maaiveld. 


\section{Bijlage 3 Logboek pompaansturing}

Tabel 1. Gegevens pompaansturing perceel 13 en 14 (2017)

\begin{tabular}{|c|c|c|c|c|c|c|c|c|c|c|c|}
\hline \multirow[t]{2}{*}{ Datum } & \multirow{2}{*}{$\begin{array}{l}\text { Verwachting } \\
\text { neerslag (mm) }\end{array}$} & \multirow{2}{*}{$\begin{array}{l}\text { Grwst 1-3 } \\
\text { (cm) }\end{array}$} & \multirow{2}{*}{$\begin{array}{l}\text { Diver } \\
(\mathrm{cm})\end{array}$} & \multirow{2}{*}{$\begin{array}{c}\text { Peil } \\
\text { reservoir }(\mathrm{cm})\end{array}$} & \multicolumn{4}{|c|}{ Nieuw in te stellen reservoir peil (cm) } & \multirow[t]{2}{*}{ Aan-/afvoer } & \multicolumn{2}{|c|}{ Tellerstand (m3) } \\
\hline & & & & & Aan-Min & Aan-Max & Af-Min & Af-Max & & Aanvoer & Afvoer \\
\hline 2-jun & nee & 43 & -50 & 140 & & & & & aan & 1814 & -1166 \\
\hline 6-jun & ja & & -51 & & & & & & 0 & 1873 & -1166 \\
\hline 9-jun & ja & 41 & -48 & 147 & & & & & 0 & & \\
\hline 13-jun & 0 & 45 & -49 & 151 & & & 110 & 120 & aan-1 & & \\
\hline 16-jun & 0 & 46 & -50 & & & & 110 & 120 & aan-1 & 1924 & -1167 \\
\hline 22-jun & 0 & 47 & -53 & & & & 110 & 120 & aan-1 & & \\
\hline 28-jun & ja & 43 & -50 & & & & & & 0 & & \\
\hline 29-jun & ja & & -45 & & & & 120 & 130 & aan-2 & 2125 & -1168 \\
\hline 30-jun & ja & 42 & -46 & & & & 110 & 120 & aan-1 & & \\
\hline 7-jul & ja & 38 & -41 & & & & & & 0 & & \\
\hline 12-jul & ja & & -39 & & & & & & 0 & & \\
\hline 14-jul & ja & 39 & -36 & & & & & & 0 & 2287 & -1170 \\
\hline 17-jul & ja & & -39 & 142 & & & & & 0 & & \\
\hline 22-jul & 14 & 44 & & & & & 110 & 120 & aan1 & 2287 & -1170 \\
\hline 30-jul & 3 & 27 & & & 110 & 120 & & & $\mathrm{AF}$ & 2360 & -1171 \\
\hline 31-jul & 3 & & & & 160 & 170 & & & $\mathrm{AF}$ & & \\
\hline 4-aug & 0 & 33 & & & 160 & 170 & & & 0 & 2360 & -1215 \\
\hline 7-aug & 15 & 34 & & & 160 & 170 & & & $\mathrm{AF}$ & 2360 & -1215 \\
\hline 8-aug & 15 & 36 & & & 160 & 170 & & & $\mathrm{AF}$ & & \\
\hline 9-aug & 4 & 35 & & & 160 & 170 & & & $\mathrm{AF}$ & 2360 & -1229 \\
\hline 10-aug & 6 & 38 & & & & & & & 0 & 2360 & -1235 \\
\hline 11-aug & 3 & 38 & -39 & & & & & & 0 & & \\
\hline 14-aug & 5 & 38 & -39 & 144 & & & & & 0 & & \\
\hline 16-aug & 6 & 39 & -39 & 143 & & & & & 0 & & \\
\hline 18-aug & 5 & 38 & -39 & 143 & & & & & 0 & & \\
\hline 21-aug & 0 & 36 & -37 & 141 & & & 110 & 120 & aan-1 & 2360 & -1235 \\
\hline 23-aug & 0 & 37 & -38 & & & & 110 & 120 & aan-1 & & \\
\hline 25 -aug & 0 & 40 & -40 & & & & 110 & 120 & aan-1 & & \\
\hline 28-aug & 10 & 39 & -41 & & & & & & 0 & 2395 & -1235 \\
\hline 29-aug & 25 & 39 & -41 & 146 & & & & & 0 & & \\
\hline 31-aug & 5 & 36 & -37 & 140 & & & & & 0 & & \\
\hline 4-sep & 3 & 39 & -39 & 144 & & & & & 0 & & \\
\hline 6-sep & 18 & 41 & -40 & 145 & & & & & 0 & & \\
\hline 8-sep & 10 & plas & -36 & 139 & 165 & 175 & & & af & & \\
\hline 11-sep & 10 & $26(1)$ & -26 & & 165 & 175 & & & af & & \\
\hline 12-sep & 15 & $26(2)$ & -25 & & 165 & 175 & & & af & & -1283 \\
\hline 13-sep & 15 & $25(2)$ & -24 & & 165 & 175 & & & af & & -1295 \\
\hline 15-sep & 20 & $23(1)$ & -22 & & 170 & 180 & & & af & & -1317 \\
\hline 18-sep & 5 & $27(2)$ & -21 & & 170 & 180 & & & af & & -1367 \\
\hline 19-sep & 0 & 20 & -21 & & 170 & 180 & & & af & & -1381 \\
\hline 21-sep & 0 & 20 & -23 & & 170 & 180 & & & af & & -1413 \\
\hline 22-sep & 0 & 20 & -24 & & 170 & 180 & & & af & & -1424 \\
\hline 28-sep & 10 & & -32 & & 170 & 180 & & & af & & \\
\hline 29-sep & 9 & 27 & -30 & & 170 & 180 & & & af & & -1495 \\
\hline 2-okt & 10 & $22(2)$ & -27 & & 170 & 180 & & & af & & -1516 \\
\hline 3-okt & 15 & 25 & -29 & & 170 & 180 & & & af & & \\
\hline 4-okt & 15 & 25 & -30 & & 170 & 180 & & & af & & \\
\hline 6-okt & 10 & & -24 & & 170 & 180 & & & af & & \\
\hline 9-okt & 6 & $20(1)$ & -21 & & 170 & 180 & & & af & 2396 & -1572 \\
\hline 13-okt & 0 & $23(2)$ & -21 & & 170 & 180 & & & af & & -1605 \\
\hline 16-okt & 5 & $24(2)$ & -24 & & 170 & 180 & & & af & & \\
\hline 20-okt & 5 & 29 & -26 & & 170 & 180 & & & af & & \\
\hline 27-okt & 2 & 28 & -23 & & 170 & 180 & & & af & & \\
\hline 30-okt & 0 & 25 & -26 & & 170 & 180 & & & af & & -1721 \\
\hline 3-nov & 10 & & -29 & & 170 & 180 & & & af & & \\
\hline 6-nov & 5 & 26 & -27 & & 170 & 180 & & & af & & -1758 \\
\hline
\end{tabular}


Tabel 2. Gegevens pompaansturing perceel 15 en 16 (2017)

\begin{tabular}{|c|c|c|c|c|c|c|c|c|c|c|c|}
\hline \multirow[t]{2}{*}{ Datum } & \multirow{2}{*}{$\begin{array}{l}\text { Verwachting } \\
\text { neerslag (mm) }\end{array}$} & \multirow{2}{*}{$\begin{array}{l}\text { Grwst 1-3 } \\
\text { (cm) }\end{array}$} & \multirow{2}{*}{$\begin{array}{l}\text { Diver } \\
(\mathrm{cm})\end{array}$} & \multirow{2}{*}{$\begin{array}{c}\text { Peil } \\
\text { reservoir }(\mathrm{cm})\end{array}$} & \multicolumn{4}{|c|}{ Nieuw in te stellen reservoir peil $(\mathrm{cm})$} & \multirow[t]{2}{*}{ Aan-/afvoer } & \multicolumn{2}{|c|}{ Tellerstand (m3) } \\
\hline & & & & & Aan-Min & Aan-Max & Af-Min & Af-Max & & Aanvoer & Afvoer \\
\hline 2-jun & nee & 41 & -40 & & & & 110 & 120 & aan & 1317 & -4510 \\
\hline 6-jun & ja & & -42 & & & & & & 0 & 1351 & -4672 \\
\hline 9-jun & ja & 41 & -39 & 146 & & & & & & & \\
\hline 13-jun & 0 & 50 & -51 & 158 & & & 110 & 120 & aan & & \\
\hline 16-jun & 0 & 43 & -48 & & & & 100 & 110 & aan-2 & 1353 & -4798 \\
\hline 22 -jun & 0 & 43 & -41 & & & & & & & & \\
\hline 23 -jun & ja & & & & & & 110 & 120 & aan-1 & 1358 & -5427 \\
\hline 28-jun & ja & 41 & -41 & & & & & & 0 & & \\
\hline 29-jun & ja & & -41 & 147 & & & 120 & 130 & aan & 1359 & -5602 \\
\hline 30-jun & ja & 43 & -43 & & & & & & 0 & & \\
\hline 7-jul & ja & 41 & -41 & & & & & & 0 & & \\
\hline 12-jul & ja & & & & & & & & 0 & & \\
\hline 14-jul & ja & 43 & & & & & & & 0 & 1374 & -5838 \\
\hline 17-jul & 14 & & & 153 & & & 120 & 130 & aan-1 & 1374 & -5838 \\
\hline 22-jul & 3 & 41 & & & & & 120 & 130 & aan-1 & & \\
\hline 30-jul & 3 & 38 & & & 110 & 120 & & & af & 1526 & -6186 \\
\hline 31-jul & 0 & 28 & & & 150 & 160 & & & af & 1526 & -6186 \\
\hline 4-aug & 15 & 34 & & & & & & & 0 & 1531 & -6187 \\
\hline 7-aug & 15 & 38 & & & 150 & 160 & & & af & & \\
\hline 8-aug & 4 & 39 & & & & & & & 0 & 1552 & -6187 \\
\hline 9-aug & 4 & 40 & & 153 & & & & & 0 & & \\
\hline 10-aug & 6 & & & 152 & & & 120 & 130 & aan-1 & & \\
\hline 11-aug & 3 & 43 & & 150 & & & 120 & 130 & aan-1 & & \\
\hline 14-aug & 5 & 41 & & & & & 120 & 130 & aan-1 & & \\
\hline 16-aug & 6 & 41 & & & & & & & 0 & & \\
\hline 18-aug & 5 & 38 & & & & & 120 & 130 & aan-1 & 1556 & -6207 \\
\hline 21-aug & 0 & 37 & & 147 & & & 120 & 130 & aan-1 & & \\
\hline 23-aug & 0 & 39 & & & & & 120 & 130 & aan-1 & & \\
\hline 25 -aug & 0 & 40 & & & & & 120 & 130 & aan-1 & & \\
\hline 28 -aug & 10 & 41 & & & & & 120 & 130 & aan-1 & & \\
\hline 29-aug & 25 & 41 & & & & & & & 0 & 1562 & -6397 \\
\hline 31-aug & 5 & 38 & & & & & & & 0 & & \\
\hline 4-sep & 3 & 42 & & 153 & & & 120 & 130 & aan-1 & 1562 & -6397 \\
\hline 6-sep & 18 & 41 & & & & & & & 0 & 1563 & -6423 \\
\hline 8-sep & 10 & $p$ & & 145 & 165 & 175 & & & af & & \\
\hline 11-sep & 10 & 26 & & & 165 & 175 & & & af & & \\
\hline 12-sep & 15 & $30(2)$ & & & 165 & 175 & & & af & 1628 & \\
\hline 13-sep & 15 & $30(2)$ & & & 165 & 175 & & & af & 1644 & \\
\hline 15-sep & 20 & $26(2)$ & & & 170 & 180 & & & af & 1675 & \\
\hline 18-sep & 5 & $27(2)$ & & & 170 & 180 & & & af & & \\
\hline 19-sep & 0 & 20 & & & 170 & 180 & & & af & & \\
\hline 21-sep & 0 & 25 & -41 & & 170 & 180 & & & af & 1790 & \\
\hline 22-sep & 0 & 26 & -44 & & 170 & 180 & & & af & & \\
\hline 28-sep & & & -42 & & 170 & 180 & & & af & & \\
\hline 29-sep & 9 & 35 & -41 & & 170 & 180 & & & af & 1884 & \\
\hline 2-okt & 10 & 32 & -44 & & 170 & 180 & & & af & & \\
\hline 3-okt & 15 & 37 & -45 & & 170 & 180 & & & af & & \\
\hline 4-okt & 15 & 35 & -49 & & 170 & 180 & & & af & & \\
\hline 6-okt & 10 & & -19 & & 170 & 180 & & & af & & \\
\hline 9-okt & 6 & $26(2)$ & -17 & & 170 & 180 & & & af & 1983 & -6427 \\
\hline 13-okt & 0 & 23 & -30 & & 170 & 180 & & & af & 2027 & \\
\hline 16-okt & 5 & 27 & -40 & & 170 & 180 & & & af & & \\
\hline 20-okt & 5 & 35 & -46 & & 170 & 180 & & & af & & \\
\hline 27-okt & 2 & 34 & -43 & & 170 & 180 & & & af & & \\
\hline 30-okt & 0 & 32 & -44 & & 170 & 180 & & & af & & \\
\hline 3-nov & 10 & & -49 & & 170 & 180 & & & af & & \\
\hline 6-nov & 5 & 32 & -35 & & 170 & 180 & & & af & 2190 & \\
\hline
\end{tabular}




\section{Bijlage 4 Variatie in grondwaterstanden}

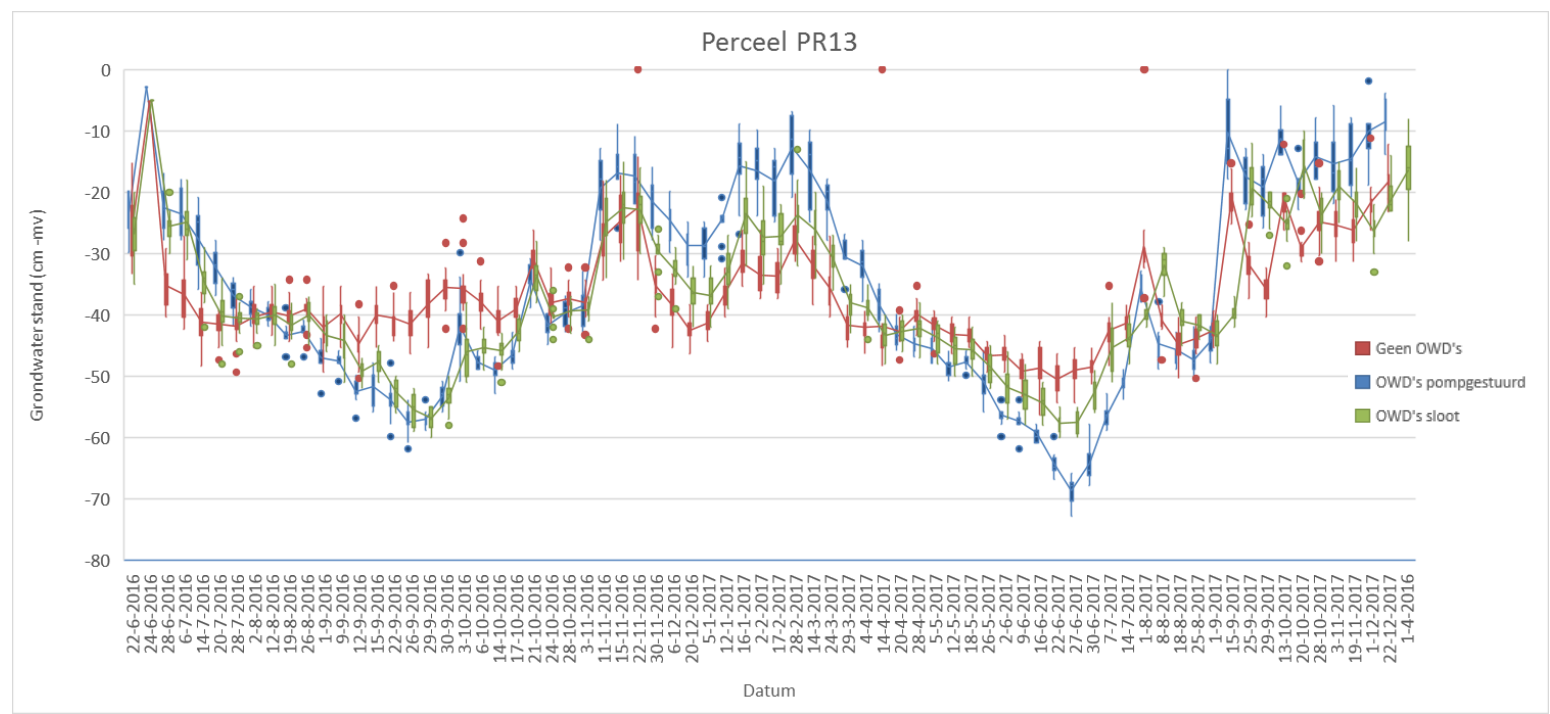

Figuur 1. Verloop van en variatie in grondwaterstand per drainbehandeling (Geen onderwaterdrains, Onderwaterdrains op de sloot en Pompgestuurde onderwaterdrains) voor perceel 13 bij een vast hoog slootpeil met een drooglegging van $20 \mathrm{~cm}$ beneden maaiveld.

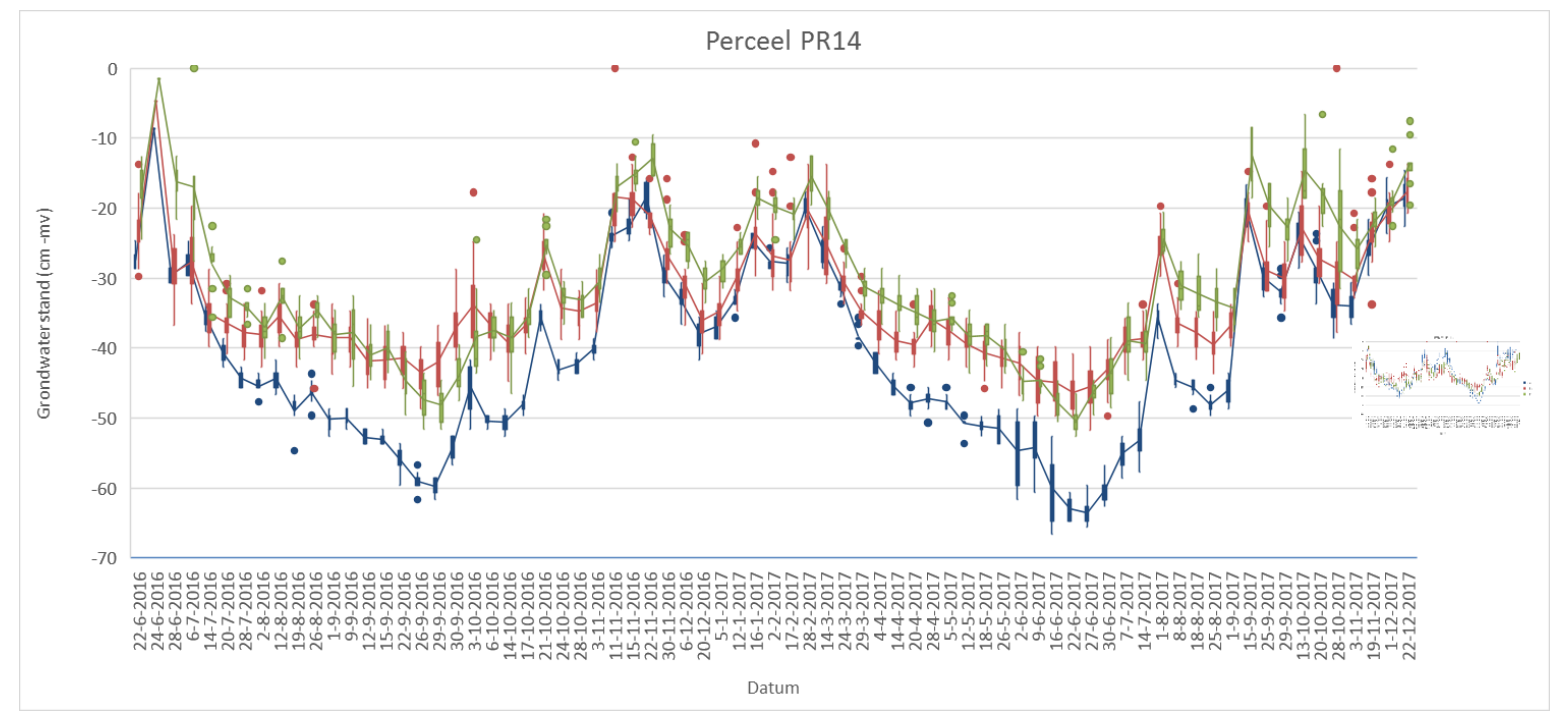

Figuur 2. Verloop van en variatie in grondwaterstand per drainbehandeling (Geen onderwaterdrains, Onderwaterdrains op de sloot en Pompgestuurde onderwaterdrains) voor perceel 14 bij een vast hoog slootpeil met een drooglegging van $20 \mathrm{~cm}$ beneden maaiveld. 


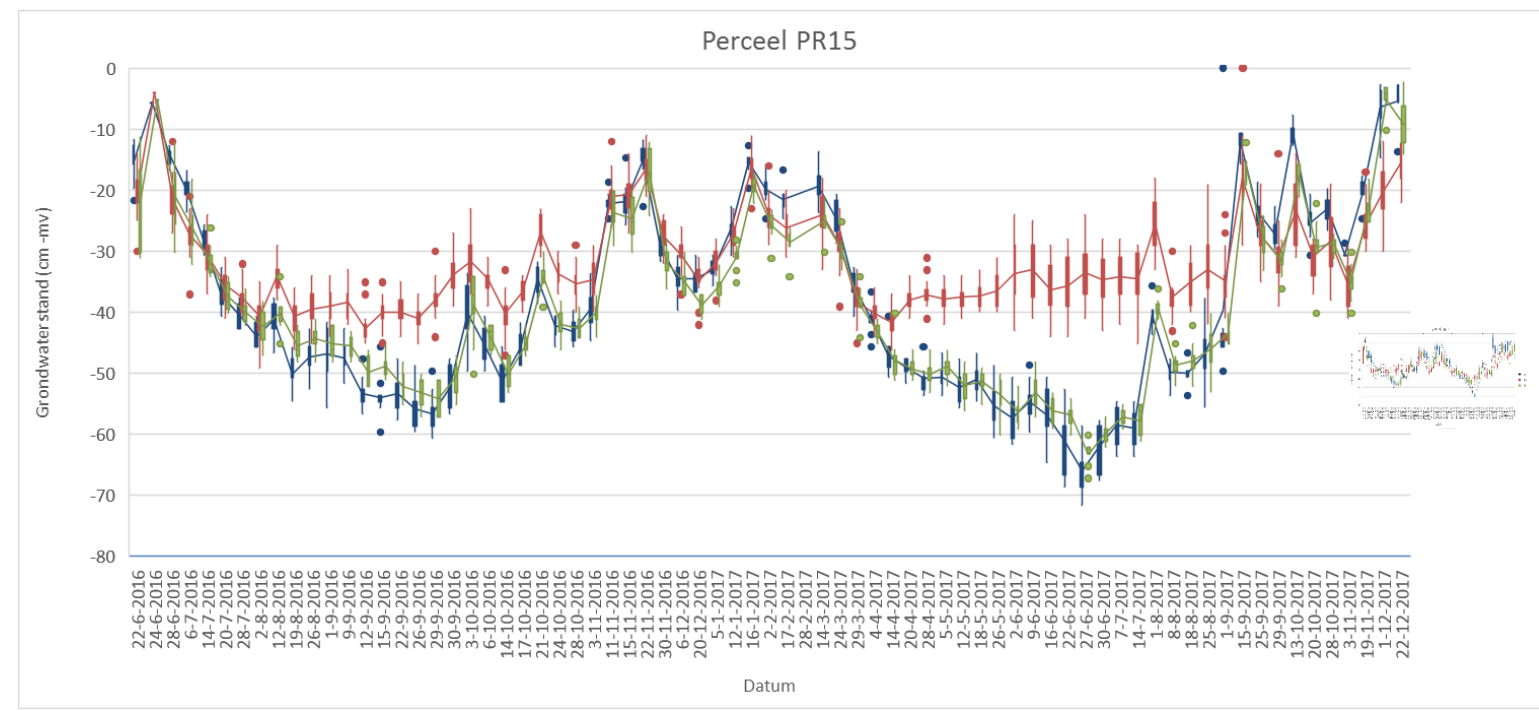

Figuur 3. Verloop van en variatie in grondwaterstand per drainbehandeling (Geen onderwaterdrains, Onderwaterdrains op de sloot en Pompgestuurde onderwaterdrains) voor perceel 15 bij een vast hoog slootpeil met een drooglegging van $55 \mathrm{~cm}$ beneden maaiveld.

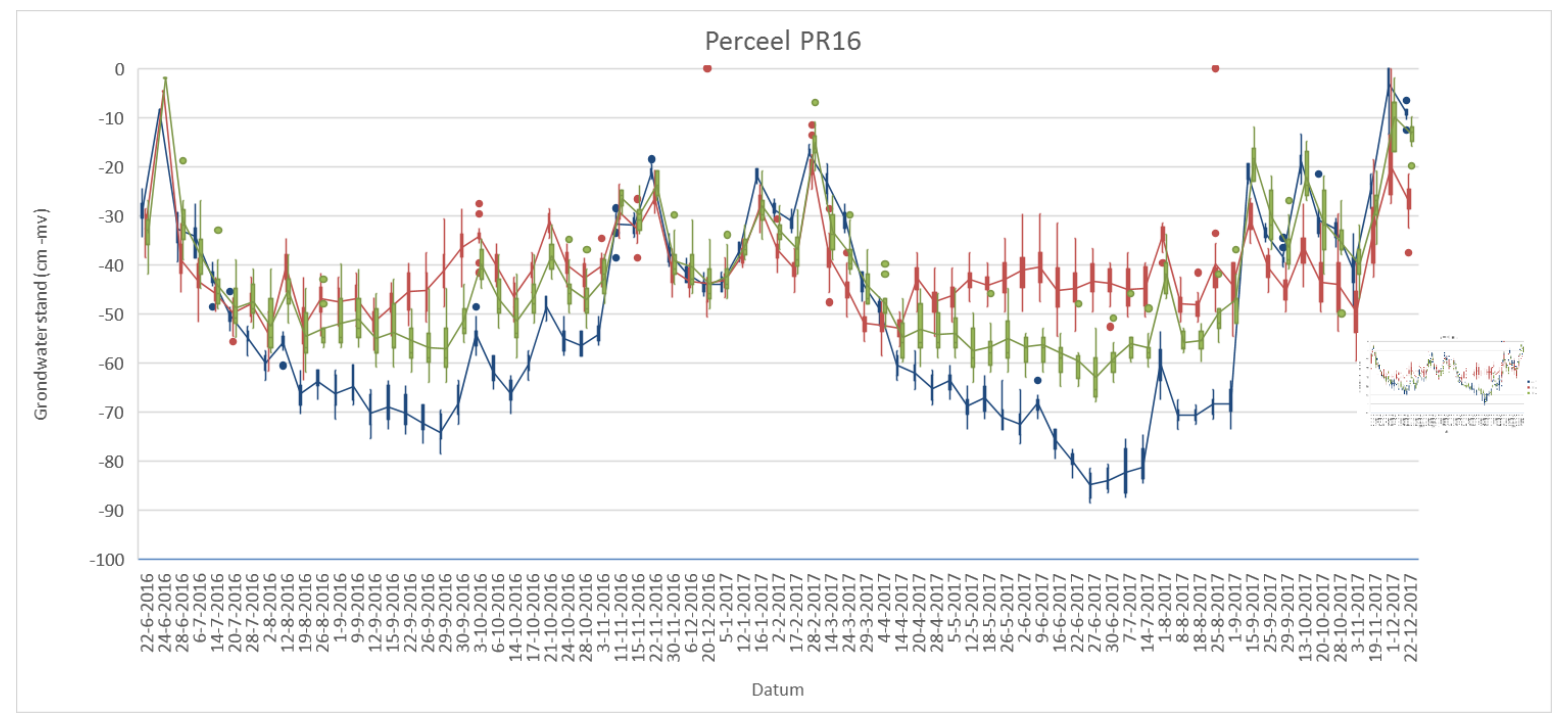

Figuur 4. Verloop van en variatie in grondwaterstand per drainbehandeling (Geen onderwaterdrains, Onderwaterdrains op de sloot en Pompgestuurde onderwaterdrains) voor perceel 16 bij een vast hoog slootpeil met een drooglegging van $55 \mathrm{~cm}$ beneden maaiveld. 


\section{Bijlage 5 Vergelijk metingen grondwaterstand}

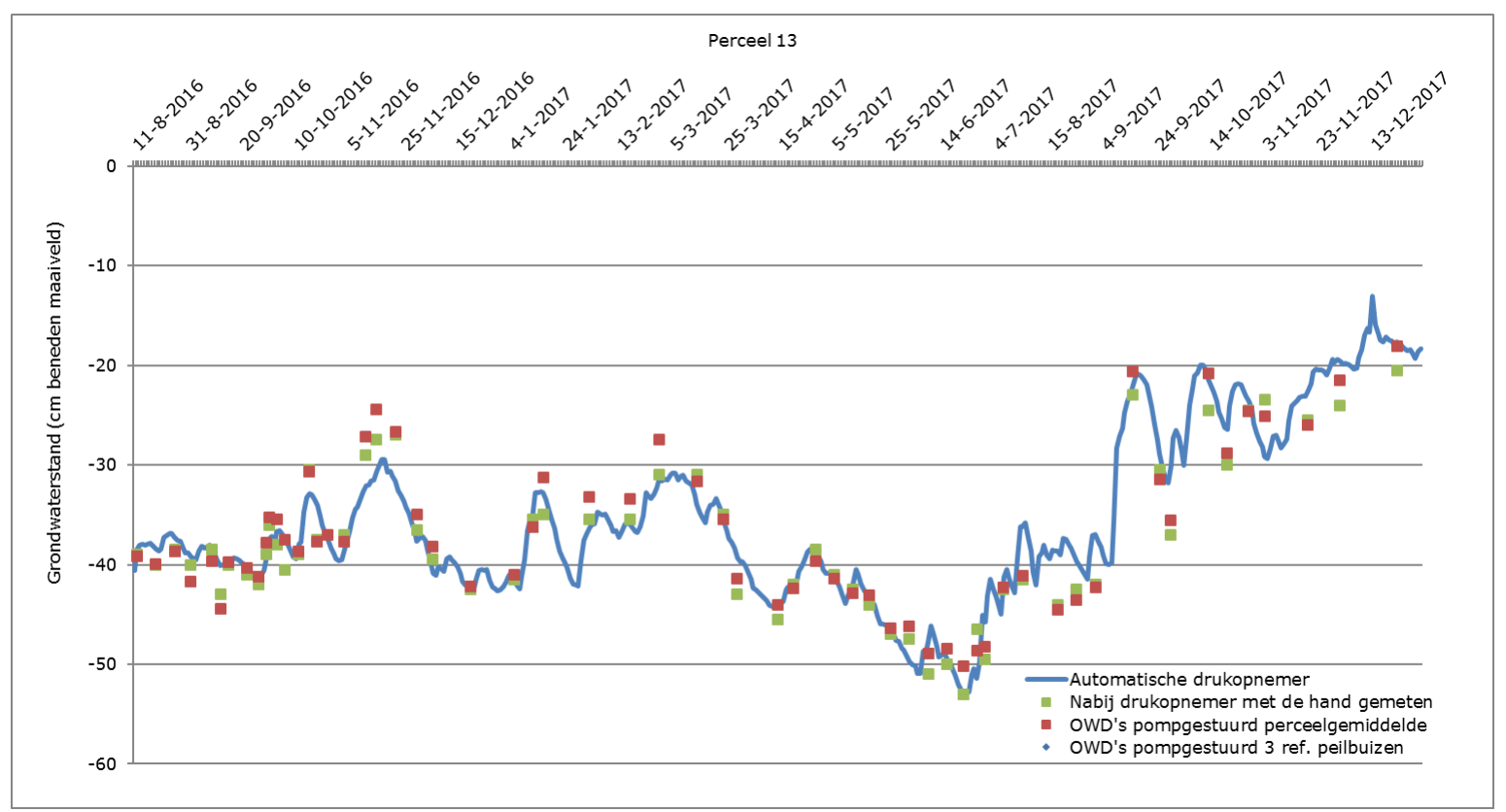

Figuur 1. Grondwaterstanden gemeten op het object Pompgestuurde onderwaterdrains van perceel 13 met een automatische drukopnemer (1 peilbuis), handmatig nabij de drukopnemer, het gemiddelde van drie referentiebuizen, die gebruikt werden voor de peilaansturing, en het gemiddelde van alle handmatig gemeten peilbuizen.

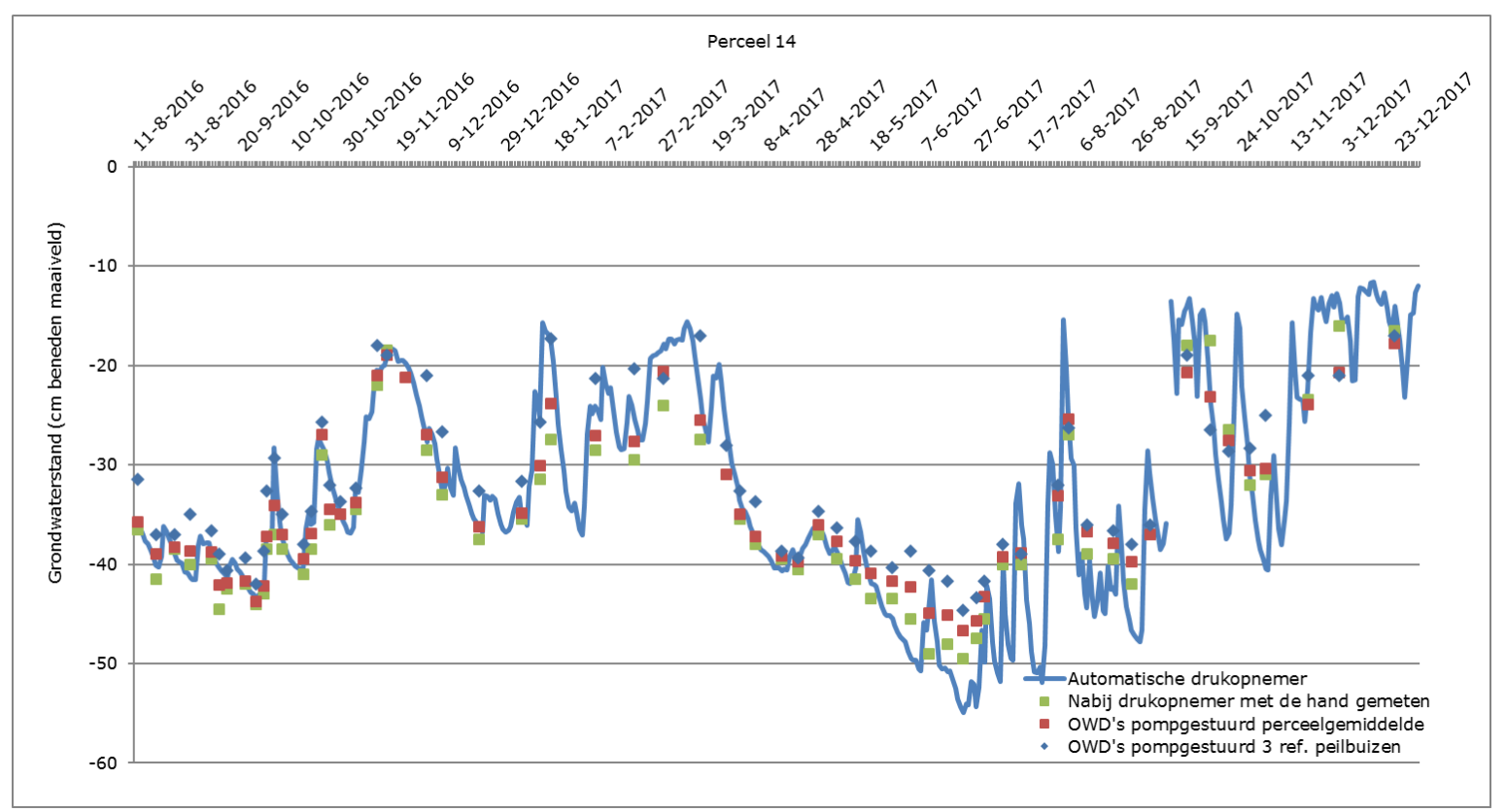

Figuur 2. Grondwaterstanden gemeten op het object Pompgestuurde onderwaterdrains van perceel 14 met een automatische drukopnemer (1 peilbuis), handmatig nabij de drukopnemer, het gemiddelde van drie referentiebuizen, die gebruikt werden voor de peilaansturing, en het gemiddelde van alle handmatig gemeten peilbuizen. 


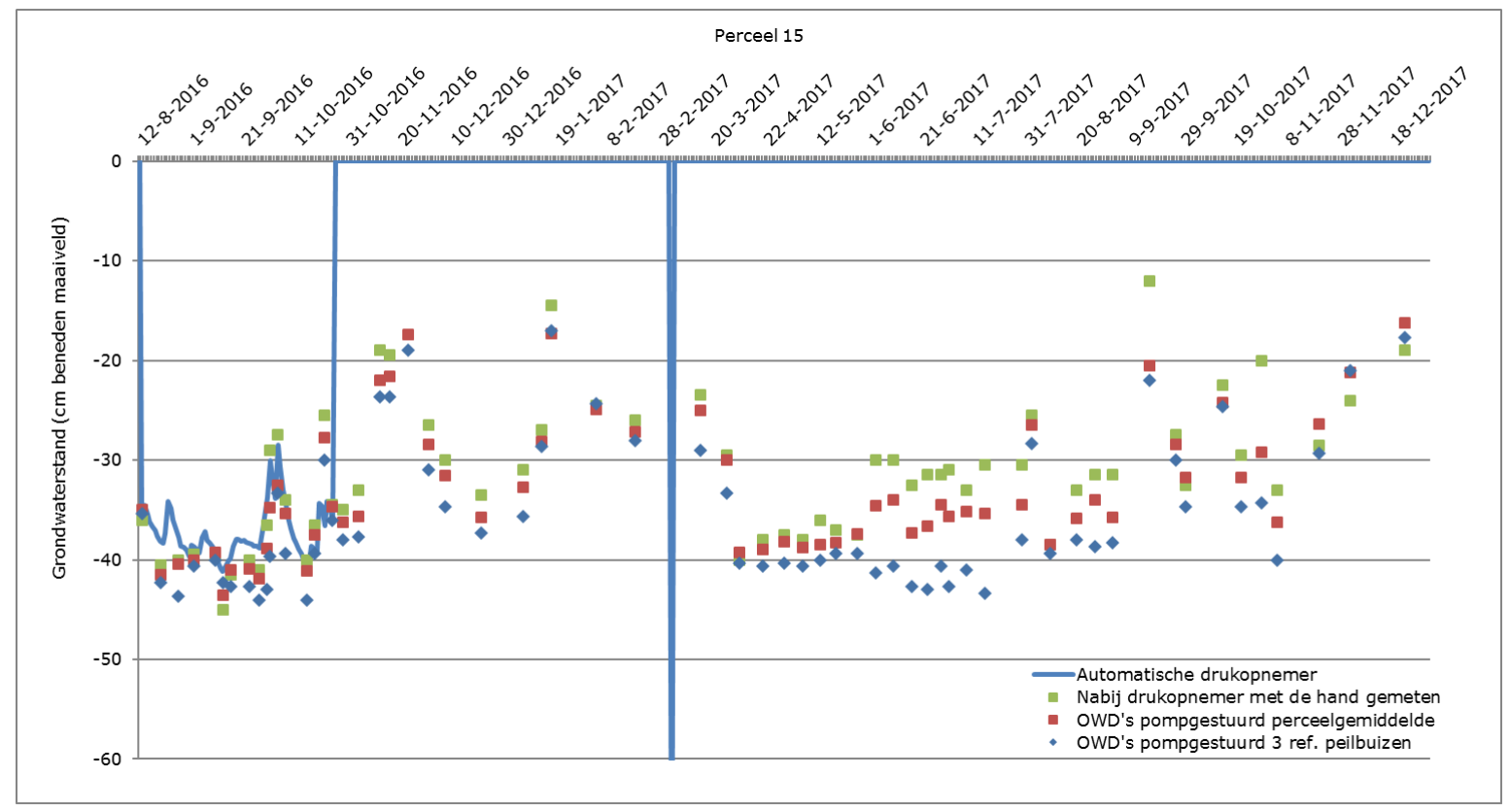

Figuur 3. Grondwaterstanden gemeten op het object Pompgestuurde onderwaterdrains van perceel 15 met een automatische drukopnemer (1 peilbuis), handmatig nabij de drukopnemer, het gemiddelde van drie referentiebuizen, die gebruikt werden voor de peilaansturing, en het gemiddelde van alle handmatig gemeten peilbuizen.

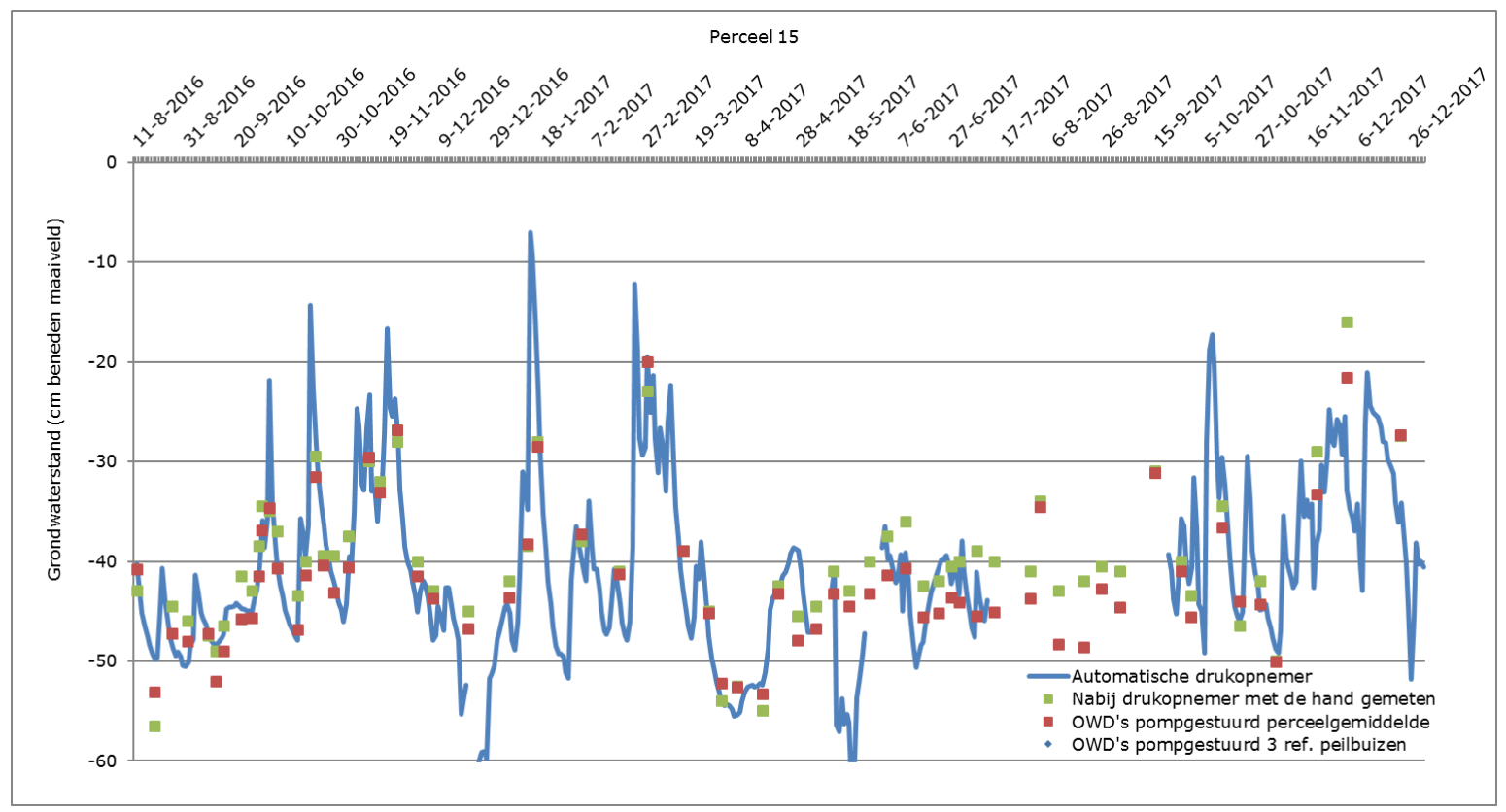

Figuur 4. Grondwaterstanden gemeten op het object Pompgestuurde onderwaterdrains van perceel 16 met een automatische drukopnemer (1 peilbuis), handmatig nabij de drukopnemer, het gemiddelde van drie referentiebuizen, die gebruikt werden voor de peilaansturing, en het gemiddelde van alle handmatig gemeten peilbuizen. 


\section{Bijlage 6 Grasopbrengst}

Tabel 1. Grasopbrengsten snede 1 tot en met 5 en de totale jaaropbrengst gemeten per perceel per veld in 2016 voor de objecten Pompgestuurde onderwaterdrains met en zonder N-bemesting ( $P$-N1 en $P$-NO), Geen onderwaterdrains met en zonder N-bemesting ( $C-N 1$ en $C-N O$ ) en Onderwaterdrains op de sloot met en zonder N-bemesting (S-NO en S-N1)

\begin{tabular}{|c|c|c|c|c|c|c|c|c|}
\hline Perceel & Veldnr. & Object & 1 & 2 & 3 & 4 & 5 & Totaal \\
\hline \multirow[t]{12}{*}{ PR13 } & 1 & P-NO & 2876 & 2149 & 2128 & 1664 & $479^{2)}$ & 9296 \\
\hline & 2 & $\mathrm{P}-\mathrm{N} 1$ & 4134 & 2232 & 2060 & 2639 & $519^{2)}$ & 11582 \\
\hline & 3 & P-NO & 3209 & 1566 & 1954 & 1589 & $500^{2)}$ & 8818 \\
\hline & 4 & P-N1 & 4160 & 2557 & 2879 & 3215 & $430^{2)}$ & 13240 \\
\hline & 5 & $\mathrm{C}-\mathrm{N} 1$ & 3343 & 2142 & 3080 & 2662 & $454^{2)}$ & 11681 \\
\hline & 6 & $\mathrm{C}-\mathrm{NO}$ & 2902 & 1629 & 2181 & 1789 & $423^{2)}$ & 8924 \\
\hline & 7 & $\mathrm{C}-\mathrm{NO}$ & 2750 & 1449 & 2161 & 1915 & $241^{2)}$ & 8516 \\
\hline & 8 & $\mathrm{C}-\mathrm{N} 1$ & 3405 & 2393 & 2049 & 2878 & $361^{2)}$ & 11086 \\
\hline & 9 & S-NO & 3109 & 1443 & 2187 & 1955 & $365^{2)}$ & 9060 \\
\hline & 10 & S-N1 & 4271 & 2262 & 2296 & 3123 & $1529^{2)}$ & 13481 \\
\hline & 11 & S-N1 & 3946 & 2616 & 2482 & $3822^{1)}$ & $1538^{2)}$ & 14403 \\
\hline & 12 & S-NO & 3097 & 1928 & 2192 & 1952 & $352^{2)}$ & 9520 \\
\hline \multirow[t]{12}{*}{ PR14 } & 1 & P-N1 & 3476 & 2963 & 2493 & 3284 & $251^{2)}$ & 12467 \\
\hline & 2 & P-NO & 1868 & 1644 & 1939 & $2393^{1)}$ & $352^{2)}$ & 8196 \\
\hline & 3 & P-NO & 1847 & 2194 & 1881 & 2286 & $292^{2)}$ & 8501 \\
\hline & 4 & P-N1 & 3483 & 2983 & 2863 & $3906^{1)}$ & $379^{2)}$ & 13614 \\
\hline & 5 & $\mathrm{C}-\mathrm{NO}$ & 2216 & 1400 & 2073 & 2037 & $131^{2)}$ & 7856 \\
\hline & 6 & $\mathrm{C}-\mathrm{N} 1$ & 3194 & 2657 & 2682 & 3027 & $204^{2)}$ & 11764 \\
\hline & 7 & C-NO & 1973 & 2041 & 1523 & 2113 & $344^{2)}$ & 7995 \\
\hline & 8 & $\mathrm{C}-\mathrm{N} 1$ & 3387 & 3110 & 2499 & $3304^{1)}$ & $455^{2)}$ & 12756 \\
\hline & 9 & S-N1 & 3395 & 2336 & 2799 & 3422 & $142^{2)}$ & 12094 \\
\hline & 10 & S-NO & 2601 & 1721 & 2520 & 2003 & $304^{2)}$ & 9148 \\
\hline & 11 & S-N1 & 3958 & 2354 & 2673 & 3396 & $213^{2)}$ & 12593 \\
\hline & 12 & S-NO & 2113 & 1518 & 2224 & 2069 & $140^{2)}$ & 8064 \\
\hline \multirow[t]{12}{*}{ PR15 } & 1 & P-NO & 2598 & 1281 & 2191 & 2131 & 1536 & 9737 \\
\hline & 2 & P-N1 & 3428 & 2099 & 3561 & 2921 & 1807 & 13817 \\
\hline & 3 & P-N1 & 2902 & 1986 & 3499 & 2930 & 1898 & 13214 \\
\hline & 4 & P-NO & 2565 & 1277 & 2115 & 2309 & 1740 & 10006 \\
\hline & 5 & C-N1 & 3685 & 1976 & $2224^{1)}$ & 2814 & 2087 & 12786 \\
\hline & 6 & $\mathrm{C}-\mathrm{NO}$ & 2553 & 1419 & 2177 & 1789 & 1749 & 9686 \\
\hline & 7 & $\mathrm{C}-\mathrm{N} 1$ & $3512^{1)}$ & 2193 & 3405 & 2211 & 1851 & 13171 \\
\hline & 8 & $\mathrm{C}-\mathrm{NO}$ & 3077 & 1280 & 2230 & 2090 & 1384 & 10060 \\
\hline & 9 & S-N1 & 3646 & 1919 & 3668 & 2579 & 1953 & 13765 \\
\hline & 10 & S-NO & 2363 & 1230 & 1726 & 1712 & 1583 & 8613 \\
\hline & 11 & S-NO & 2850 & 1167 & 2089 & 1586 & 1244 & 8935 \\
\hline & 12 & S-N1 & 3761 & 1904 & 3506 & 2220 & 1735 & 13125 \\
\hline \multirow[t]{12}{*}{ PR16 } & 1 & P-NO & 2869 & 2474 & 2119 & 2162 & 1773 & 11397 \\
\hline & 2 & P-N1 & 3958 & 3565 & 2408 & 2474 & 1935 & 14341 \\
\hline & 3 & $\mathrm{P}-\mathrm{N} 1$ & 3975 & 3424 & 2609 & 3017 & 1914 & 14940 \\
\hline & 4 & P-NO & 2786 & 2604 & 2276 & 1894 & 1775 & 11335 \\
\hline & 5 & C-N1 & 3598 & 3464 & 2624 & 2588 & 1862 & 14136 \\
\hline & 6 & C-NO & 2802 & 2621 & 2318 & 1915 & 1605 & 11260 \\
\hline & 7 & $\mathrm{C}-\mathrm{NO}$ & 2905 & 2660 & 2025 & 1985 & 1678 & 11253 \\
\hline & 8 & $\mathrm{C}-\mathrm{N} 1$ & 3723 & 3544 & 2215 & 3033 & 1842 & 14358 \\
\hline & 9 & S-N1 & 3656 & 3024 & 2615 & 2882 & 1821 & 13998 \\
\hline & 10 & S-NO & 2580 & 2446 & 1926 & 1733 & 1673 & 10359 \\
\hline & 11 & S-N1 & 3322 & 3178 & 2072 & 2542 & 1790 & 12903 \\
\hline & 12 & S-NO & 2369 & 2229 & 2177 & 1919 & 1653 & 10348 \\
\hline
\end{tabular}

1) Correctie drogestofgehalte gras op basis van herhaalde waarneming vanwege grond in grasmonster

2) Verstoring grasopbrengst door weidend vee 
Tabel 2. Grasopbrengsten snede 1 tot en met 5 en de totale jaaropbrengst gemeten per perceel per veld in 2017 voor de objecten Pompgestuurde onderwaterdrains met en zonder N-bemesting ( $P$-N1 en $P$-NO), Geen onderwaterdrains met en zonder $N$-bemesting ( $C-N 1$ en $C-N O)$ en Onderwaterdrains op de sloot met en zonder N-bemesting (S-NO en S-N1)

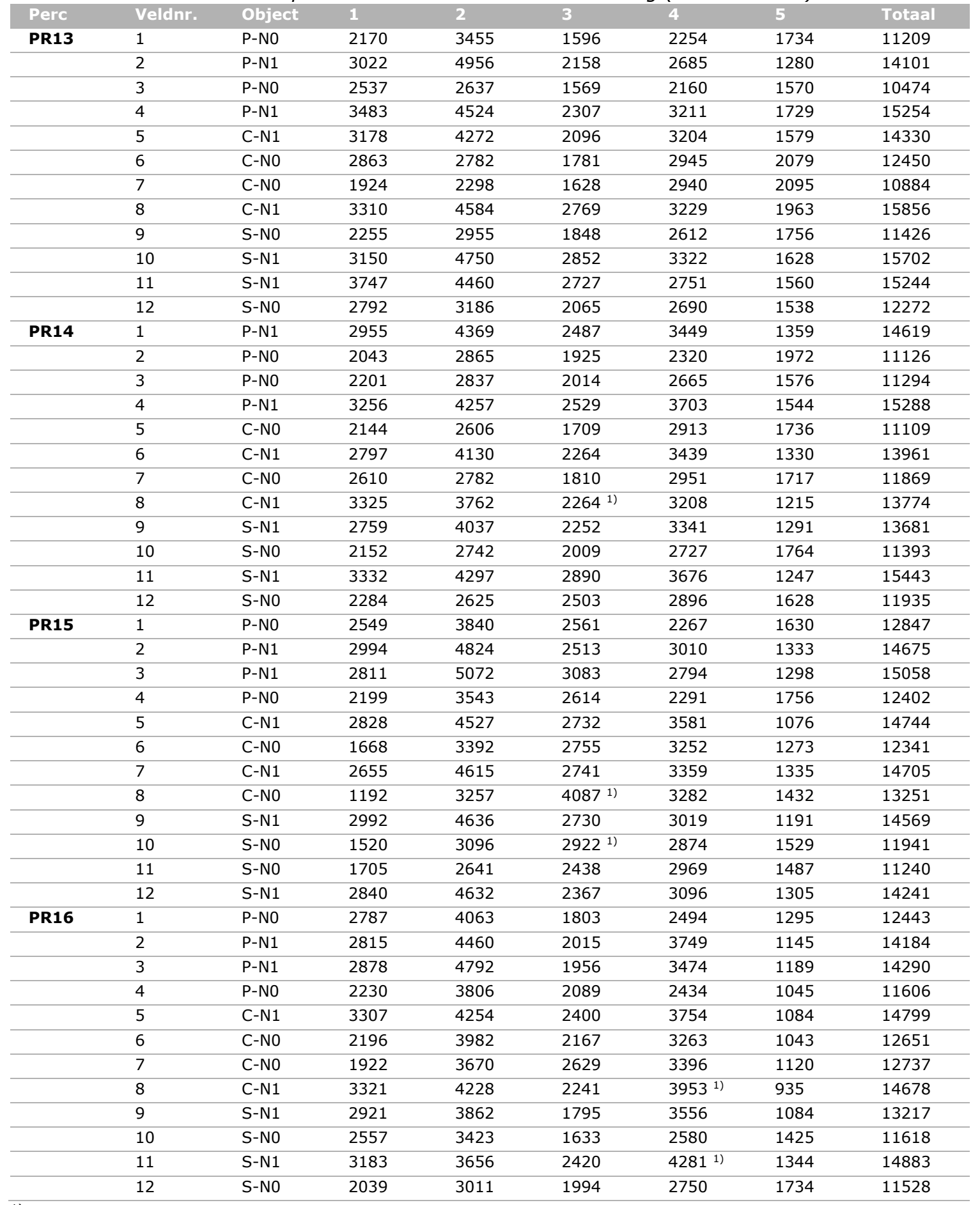

1) Correctie drogestofgehalte gras op basis van herhaalde waarneming vanwege grond in grasmonster 


\section{Bijlage 7 Stikstofopbrengst}

Tabel 1. Stikstofopbrengsten snede 1 tot en met 5 en de totale jaaropbrengst gemeten per perceel per veld in 2016 voor de objecten Pompgestuurde onderwaterdrains met en zonder $N$ bemesting ( $P$-N1 en P-NO), Geen onderwaterdrains met en zonder N-bemesting ( $C-N 1$ en $C$ NO) en Onderwaterdrains op de sloot met en zonder N-bemesting (S-NO en S-N1)

\begin{tabular}{|c|c|c|c|c|c|c|c|c|}
\hline Perc & Veldnr. & Object & 1 & 2 & 3 & 4 & 5 & Totaal \\
\hline \multirow[t]{8}{*}{ PR13 } & 1 & P-NO & 66 & 55 & 38 & 45 & $17^{2)}$ & 221 \\
\hline & 3 & $\mathrm{P}-\mathrm{NO}$ & 73 & 40 & 35 & 43 & $18^{2)}$ & 209 \\
\hline & 5 & $\mathrm{C}-\mathrm{N} 1$ & 117 & 70 & 70 & 91 & $16^{2)}$ & 364 \\
\hline & 6 & $\mathrm{C}-\mathrm{NO}$ & 64 & 44 & 38 & 52 & $14^{2)}$ & 212 \\
\hline & 7 & $\mathrm{C}-\mathrm{NO}$ & 61 & 39 & 37 & 56 & $8^{2)}$ & 201 \\
\hline & 10 & S-N1 & 147 & 74 & 47 & 96 & $44^{2)}$ & 409 \\
\hline & 11 & S-N1 & 136 & 86 & 51 & $118^{1)}$ & $44^{2)}$ & 435 \\
\hline & 12 & S-NO & 72 & 50 & 40 & 56 & $10^{2)}$ & 229 \\
\hline \multirow{8}{*}{ PR14 } & 1 & $\mathrm{P}-\mathrm{N} 1$ & 122 & 87 & 58 & 100 & $7^{21}$ & 374 \\
\hline & 2 & $\mathrm{P}-\mathrm{NO}$ & 44 & 37 & 43 & $63^{1)}$ & $9^{2)}$ & 197 \\
\hline & 3 & $\mathrm{P}-\mathrm{NO}$ & 44 & 50 & 42 & 61 & $8^{2)}$ & 204 \\
\hline & 8 & $\mathrm{C}-\mathrm{N} 1$ & 116 & 94 & 58 & $106^{1)}$ & $13^{2)}$ & 388 \\
\hline & 9 & S-N1 & 131 & 76 & 67 & 92 & $5^{2)}$ & 370 \\
\hline & 10 & S-NO & 73 & 46 & 54 & 57 & $8^{2)}$ & 239 \\
\hline & 11 & S-N1 & 152 & 76 & 64 & 91 & $72)$ & 391 \\
\hline & 12 & S-NO & 59 & 41 & 47 & 59 & $4^{2)}$ & 211 \\
\hline \multirow[t]{11}{*}{ PR15 } & 1 & P-NO & 53 & 32 & 37 & 59 & 47 & 228 \\
\hline & 2 & $\mathrm{P}-\mathrm{N} 1$ & 93 & 68 & 73 & 78 & 53 & 364 \\
\hline & 3 & $\mathrm{P}-\mathrm{N} 1$ & 79 & 64 & 71 & 78 & 56 & 348 \\
\hline & 4 & $\mathrm{P}-\mathrm{NO}$ & 52 & 32 & 36 & 64 & 53 & 237 \\
\hline & 5 & $\mathrm{C}-\mathrm{N} 1$ & 90 & 65 & $40^{1)}$ & 85 & 71 & 352 \\
\hline & 6 & $\mathrm{C}-\mathrm{NO}$ & 52 & 34 & 39 & 47 & 59 & 230 \\
\hline & 8 & C-NO & 62 & 31 & 39 & 55 & 47 & 234 \\
\hline & 9 & S-N1 & 96 & 68 & 74 & 78 & 68 & 384 \\
\hline & 10 & S-NO & 52 & 30 & 30 & 47 & 49 & 207 \\
\hline & 11 & S-NO & 62 & 28 & 36 & 44 & 39 & 209 \\
\hline & 12 & S-N1 & 99 & 68 & 71 & 67 & 60 & 365 \\
\hline \multirow[t]{12}{*}{ PR16 } & 1 & $\mathrm{P}-\mathrm{NO}$ & 65 & 64 & 47 & 58 & 54 & 289 \\
\hline & 2 & $\mathrm{P}-\mathrm{N} 1$ & 130 & 126 & 55 & 73 & 60 & 442 \\
\hline & 3 & P-N1 & 130 & 121 & 59 & 89 & 59 & 458 \\
\hline & 4 & $\mathrm{P}-\mathrm{NO}$ & 64 & 67 & 50 & 51 & 54 & 286 \\
\hline & 5 & $\mathrm{C}-\mathrm{N} 1$ & 104 & 113 & 54 & 76 & 62 & 409 \\
\hline & 6 & C-NO & 56 & 62 & 51 & 53 & 51 & 272 \\
\hline & 7 & C-NO & 58 & 63 & 44 & 55 & 53 & 272 \\
\hline & 8 & $\mathrm{C}-\mathrm{N} 1$ & 108 & 116 & 46 & 89 & 61 & 420 \\
\hline & 9 & S-N1 & 124 & 100 & 56 & 86 & 59 & 425 \\
\hline & 10 & S-NO & 58 & 61 & 47 & 51 & 54 & 270 \\
\hline & 11 & S-N1 & 113 & 105 & 44 & 76 & 58 & 396 \\
\hline & 12 & S-NO & 53 & 56 & 53 & 56 & 53 & 271 \\
\hline
\end{tabular}

1) Correctie drogestofgehalte gras op basis van herhaalde waarneming vanwege grond in grasmonster

2) Verstoring grasopbrengst door weidend vee 
Tabel 2. Stikstofopbrengsten snede 1 tot en met 5 en de totale jaaropbrengst gemeten per perceel per veld in 2017 voor de objecten Pompgestuurde onderwaterdrains met en zonder $N$ bemesting ( $P$-N1 en P-NO), Geen onderwaterdrains met en zonder N-bemesting ( $C-N 1$ en $C$ NO) en Onderwaterdrains op de sloot met en zonder N-bemesting (S-NO en S-N1)

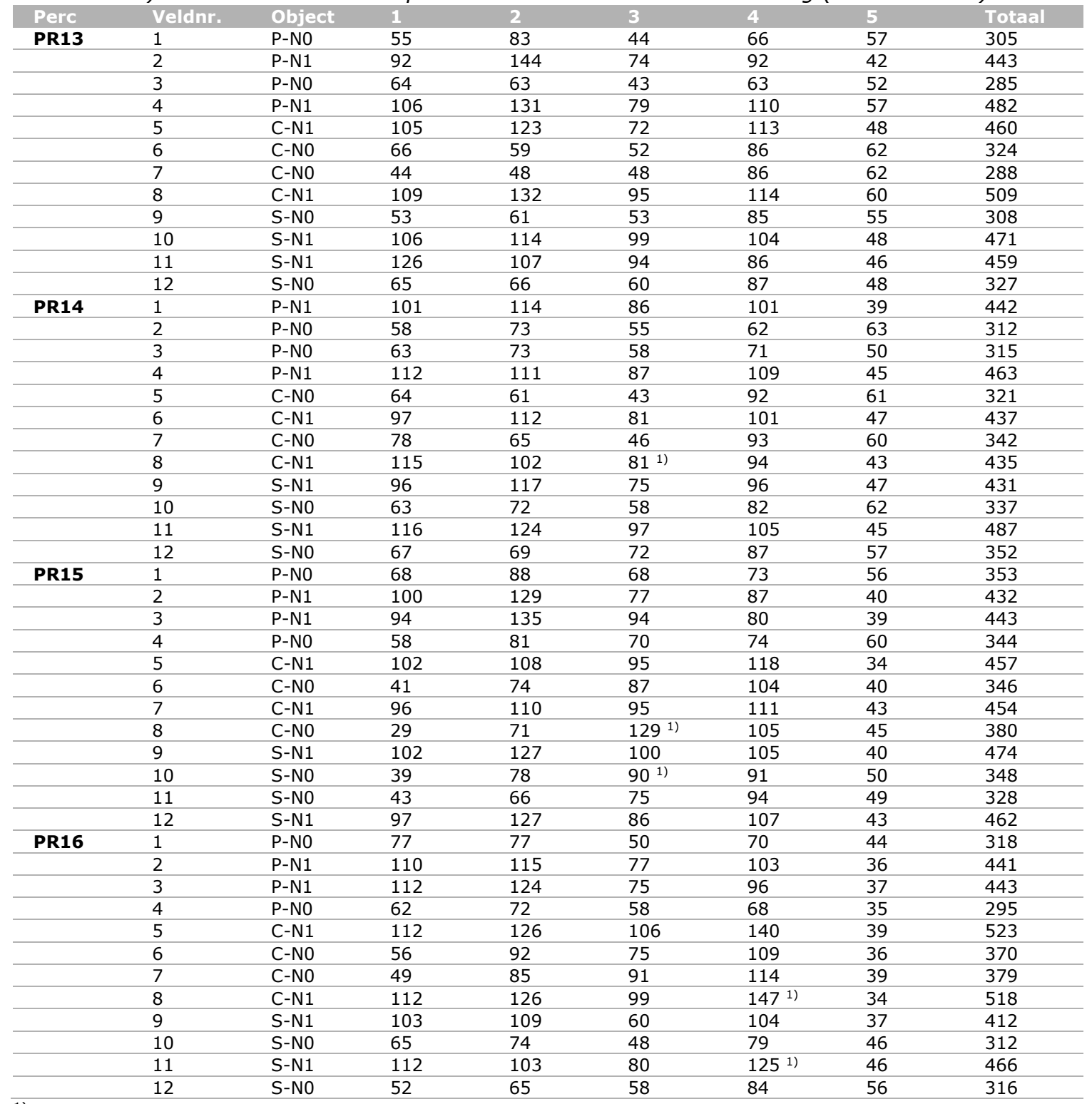

1) Correctie drogestofgehalte gras op basis van herhaalde waarneming vanwege grond in grasmonster 


\section{Bijlage 8 Botanische samenstelling}

Tabel 1. Botanische samenstelling proefpercelen voor Pompgestuurde drainage (a), Geen onderwaterdrains (b) en Onderwaterdrains op de sloot (c) gekarteerd op 26-10-2017.

\begin{tabular}{|c|c|c|c|c|c|c|c|c|c|c|c|c|}
\hline Perceel & $13 a$ & $13 b$ & $13 c$ & $14 a$ & $14 b$ & $14 c$ & $15 a$ & $15 b$ & $15 c$ & $16 a$ & $16 b$ & $16 c$ \\
\hline Bedekking \% & 98 & 98 & 98 & 98 & 98 & 98 & 98 & 98 & 98 & 98 & 98 & 98 \\
\hline Engels raaigras & 57 & 57 & 61 & 53 & 58 & 51 & 55 & 54 & 48 & 69 & 67 & 69 \\
\hline \multicolumn{13}{|l|}{ Italiaans raaigras } \\
\hline timotheegras & + & + & + & + & + & + & 8 & 12 & 12 & 6 & 5 & 8 \\
\hline \multicolumn{13}{|l|}{ rietzwenkgras } \\
\hline witte klaver & + & & & & & & & & & & & \\
\hline ruw beemdgras & 24 & 22 & 20 & 25 & 25 & 25 & 18 & 16 & 18 & 15 & 15 & 12 \\
\hline kweek & 3 & 2 & 3 & 5 & 3 & 4 & 2 & 1 & 2 & 1 & 2 & 1 \\
\hline fioringras & 2 & 3 & 2 & 3 & 2 & 4 & 1 & 1 & 1 & + & + & 1 \\
\hline gestreepte witbol & + & + & + & + & + & + & + & + & + & + & + & + \\
\hline \multicolumn{13}{|l|}{ veldbeemdgras } \\
\hline straatgras & 12 & 15 & 12 & 8 & 8 & 10 & 6 & 8 & 8 & 5 & 8 & 6 \\
\hline geknikte vossestaart & + & + & + & 1 & + & 1 & + & + & + & + & + & + \\
\hline grote vossenstaart & + & + & + & + & + & + & 2 & 2 & 3 & 1 & + & + \\
\hline kropaar & & + & & & & & & & & & & \\
\hline \multicolumn{13}{|l|}{ ruwe smele } \\
\hline mannagras & + & + & + & + & + & + & + & + & + & + & + & + \\
\hline zachte dravik & + & + & & & + & + & & & & & + & + \\
\hline \multicolumn{13}{|l|}{ rietgras } \\
\hline vogelmuur & & & & & & & & & & & + & \\
\hline paardebloem & + & + & + & 2 & 2 & 2 & 4 & 3 & 4 & 1 & 1 & 1 \\
\hline ridderzuring & + & + & + & + & + & + & + & + & + & + & + & + \\
\hline krulzuring & + & + & + & + & + & + & + & + & + & + & + & + \\
\hline veldzuring & + & + & + & & + & & & & + & & & \\
\hline herderstasje & + & + & + & + & + & + & & & + & & & + \\
\hline \multicolumn{13}{|l|}{ melganzevoet } \\
\hline kruipende boterbloem & 2 & 1 & 2 & 3 & 2 & 3 & 4 & 3 & 4 & 2 & 2 & 2 \\
\hline \multicolumn{13}{|l|}{ grote weegbree } \\
\hline \multicolumn{13}{|l|}{ paarse dovenetel } \\
\hline \multicolumn{13}{|l|}{ zachte ooievaarsbek } \\
\hline paarse dovenetel & + & + & + & & & & + & & & + & + & \\
\hline \multicolumn{13}{|l|}{ gewone hoornbloem } \\
\hline \multicolumn{13}{|l|}{ zwaluwtong } \\
\hline \multicolumn{13}{|l|}{ kleine vogelkers } \\
\hline \multicolumn{13}{|l|}{ akkerdistel } \\
\hline hondsdraf & + & & & & + & & & + & & & + & + \\
\hline \multicolumn{13}{|l|}{ brandnetel } \\
\hline \multicolumn{13}{|l|}{ akkerereprijs } \\
\hline \multicolumn{13}{|l|}{ gekroesde melkdistel } \\
\hline zwarte nachtschade & & & & & & & & & & & & \\
\hline
\end{tabular}

\footnotetext{
+ soort is wel aangetroffen, maar met $<1 \%$
} 


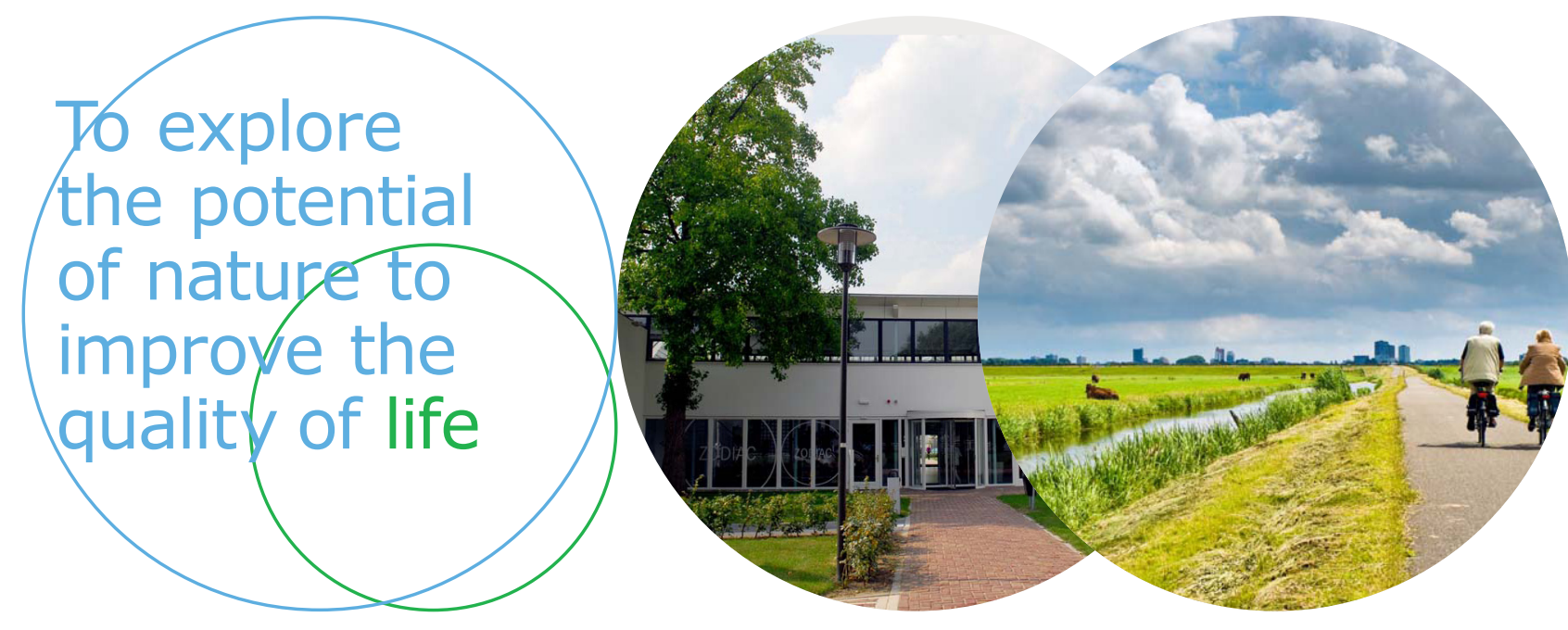

Wageningen Livestock Research Postbus 338

Wageningen Livestock Research ontwikkelt kennis voor een zorgvuldige en $6700 \mathrm{AH}$ Wageningen T 0317483953 renderende veehouderij, vertaalt deze naar praktijkgerichte oplossingen en innovaties, en zorgt voor doorstroming van deze kennis. Onze wetenschappelijke E info.livestockresearch@wur.nl www.wur.nl/ livestock-research kennis op het gebied van veehouderijsystemen en van voeding, genetica, welzijn en milieu-impact van landbouwhuisdieren integreren we, samen met onze klanten, tot veehouderijconcepten voor de $21 \mathrm{e}$ eeuw.

De missie van Wageningen University \& Research is 'To explore the potential of nature to improve the quality of life'. Binnen Wageningen University \& Research bundelen 9 gespecialiseerde onderzoeksinstituten van Stichting Wageningen Research en Wageningen University hun krachten om bij te dragen aan de oplossing van belangrijke vragen in het domein van gezonde voeding en leefomgeving. Met ongeveer 30 vestigingen, 6.500 medewerkers en 10.000 studenten behoort Wageningen University \& Research wereldwijd tot de aansprekende kennisinstellingen binnen haar domein. De integrale benadering van de vraagstukken en de samenwerking tussen verschillende disciplines vormen het hart van de unieke Wageningen aanpak. 